Geology of the

Guadalupe Mountains

New Mexico

Uii. GEOLOGICAL SURVEY, PROFESSIONAL PAPER 446
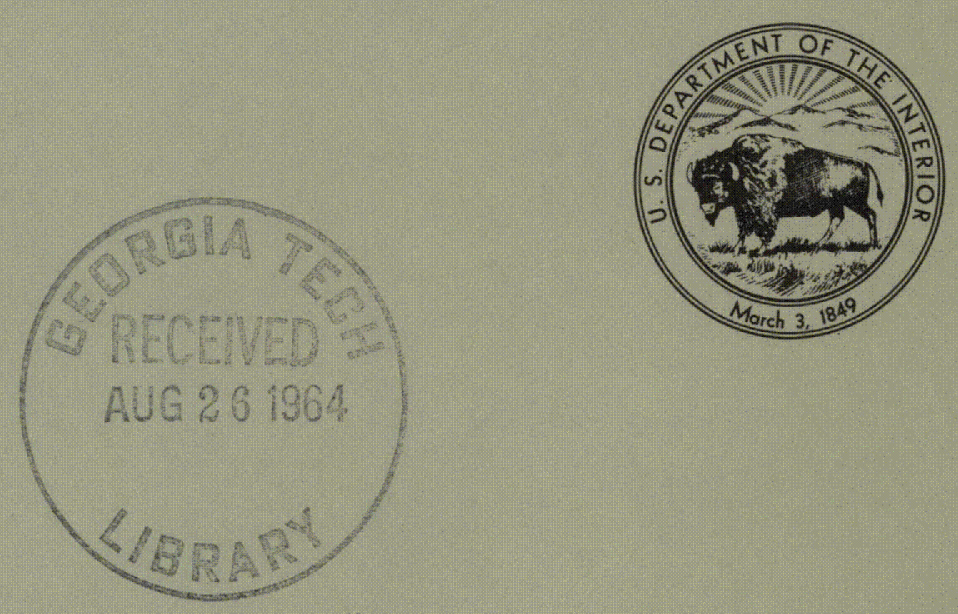



\section{Geology of the}

\section{Guadalupe Mountains}

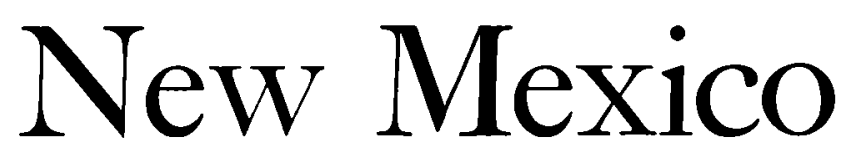

By PHILIP T. HAYES

GEOLOGICAL SURVEY PROFESSIONAL PAPER 446

Geology of a 970-square-mile area with emphasis on Permian stratigraphy
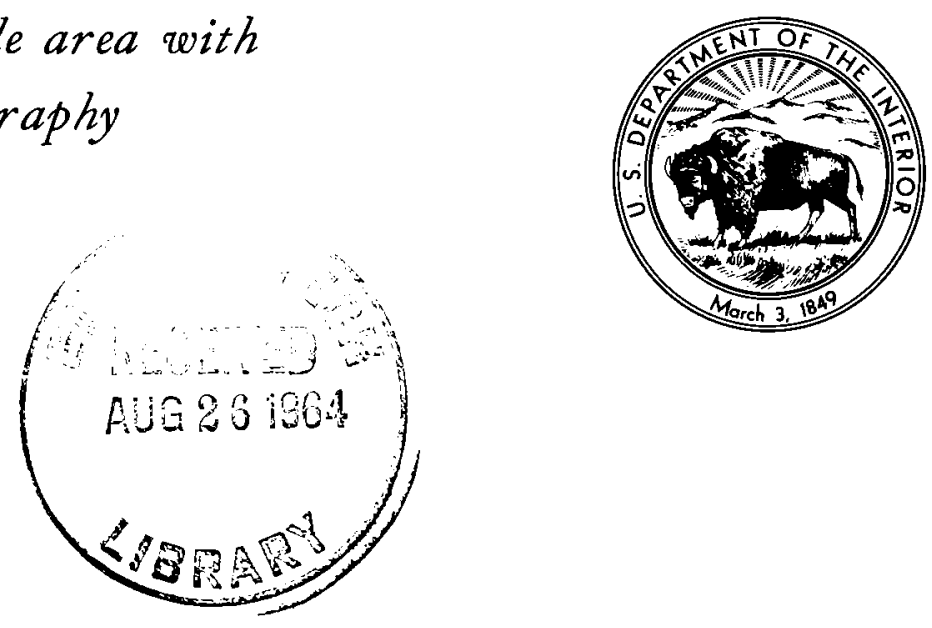


\section{UNITED STATES DEPARTMENT OF THE INTERIOR \\ STEWART L. UDALL, Secretary \\ GEOLOGIGAL SURVEY}

Thomas B. Nolan, Director

The U.S. Geological Survey Library has cataloged this publication as follows:

\section{Hayes, Philip Thayer, 1923-}

Geology of the Guadalupe Mountains, New Mexico. Washington, U.S. Govt. Print. Off., 1964.

iv, 68 p. illus., maps $(1$ col.) diagrs., tables. $29 \mathrm{~cm}$. (U.S. Geological Survey. Professional paper 446)

Part of illustrative matter fold. in pocket.

Bibliography : p. 62-65.

1. Geology-New Mexico-Guadalupe Mountains. I. Title: The Guadalupe Mountains, New Mexico. (Series)

For sale by the Superintendent of Documents, U.S. Government Printing Office Washington, D.C., 20402 


\section{CONTENTS}

Abstract... Introduction. . .

Purpose . . . . . . . . .

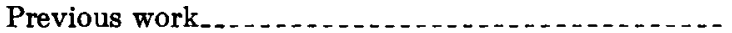

Present investigation and acknowledgments _._. - _.

Geography

Pre-Permian rocks of the subsurface

Methods of study

Precambrian rocks.

Ordovician rocks

Bliss Sandstone

El Paso Formation

Rocks correlated with the Simpson Group .... Montoya Dolomite.

Silurian rocks.

Fusselman Dolomite. . . . .

Devonian rocks

Percha(?) Shale

Mississippian rocks.

Pennsylvanian rocks.

Stratigraphy of Permian rocks....

Framework . . . . . .

Rocks of the Delaware basin.

Wolfcamp Series.............................

Wolfcamp(?) Formation .

Leonard Series. . . . . . . . . . . . . . .

Bone Spring Limestone.......

Guadalupe Series. . . . . .

Delaware Mountain Group.-..-....

Ochoa Series.

Castile Formation . . . .

Rustler Formation

Rocks of the basin margin

Wolfcamp Series.........

Leonard Series.

Victorio Peak Limestone..........

Cutoff Shale. . . . .

Guadalupe Series. . . . . . . . . . . . Sandstone tongue of the Cherry Canyon

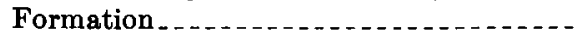

Goat Seep Dolomite.......

Capitan Limestone......

Rocks of the Northwest shelf

Hueco Limestone. . . . . . . .

Yeso Formation.

San Andres Limestone.....

Artesia Group.............

Grayburg Formation.
Page

1
Stratigraphy of Permian rocks-Continued Rocks of the Northwest shelf-Continued Artesia Group-Continued

Queen Formation.................. 30

Seven Rivers Formation $\ldots \ldots 32$

Yates Formation _. .

Tansill Formation _...................... 35

Fossils of the Artesia Group. 36

Post-Permian deposits............................... 37

Cretaceous rocks.................................. 37

Quaternary deposits $\ldots \ldots . \ldots 38$

Gravel of Pleistocene age $\ldots \ldots \ldots$

Alluvium_............................... 38

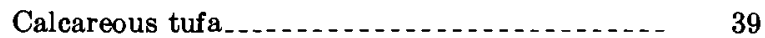

Tertiary igneous rocks._............. 39

Structural geology _......... 40

Major structural elements................... 40

Older structural features..................... 40

Huapache thrust zone.......... 40

Bone Spring monocline and Bone Spring arch..- $\quad 42$

Cenozoic structural features._._.

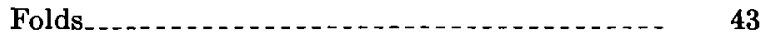

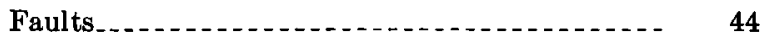

Joints _........... 45

Linear features in Castile Formation

Geomorphology

Major landforms._._._. 46

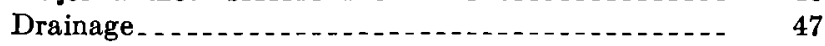

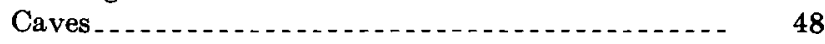

Geologic history

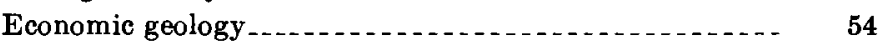

Oil and gas.

Previous exploration.

Future possibilities.

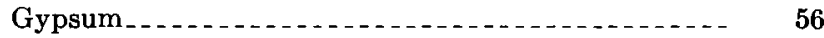

Building stone... 56

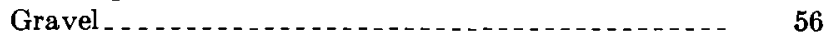

Sodium sulfate $\ldots \ldots \ldots$

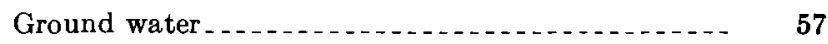

Brokeoff Mountains-Dog Canyon area $\ldots \ldots \ldots \quad 57$

Northern Guadalupe Mountains. . . . . . . . . . 58

Seven Rivers Embayment._............ 58

Guadalupe Ridge......... 58

Mescal Wash and Black River valley area $\ldots \ldots$

Yeso Hills and Gypsum Plain . . . . . . . . 58

Selected stratigraphic sections _._._._._._._._. 59

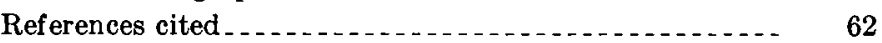

Index . 


\section{ILLUSTRATIONS}

Page

Plate 1. Geologic map and section of Guadalupe Mountains area.

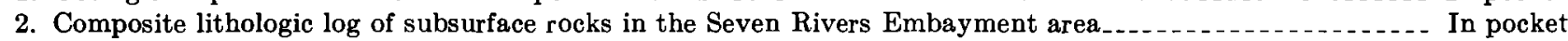

3. Graphic sections of Permian rocks and stratigraphic diagram of rocks in Guadalupe Mountains _........ In pocket

Frgure 1. Index map of Guadalupe Mountains region

2. Map of southeastern New Mexico and nearby areas showing location of mountain ranges referred to in text...- 6

3. Map of western Texas and eastern New Mexico and adjacent areas showing approximate positions of some sedimentary basins and uplifted areas

4. Diagram showing correlation of Permian rock units

5. Thin-bedded dark-gray limestone near top of the Lamar Limestone Member of the Bell Canyon Formation...-

6. Interlaminated white gypsum and dark-brownish-gray limestone in lower part of the Castile Formation......-

7. Probable residuum of the Salado Formation

8. Thin-bedded dolomite of the Rustler Formation

9. La ceral facies boundaries of some stratigraphic units of Guadalupe age

10. Northeast side of Slaughter Canyon.....

11. Photomicrograph of limestone from the massive member of the Capitan Limestone.

12. Photomicrograph of limestone from the breccia member of the Capitan Limestone:-

13. Bedding features in the lower cherty member of the San Andres Limestone in Last Chance Canyon.......

14. Diagram showing stratigraphic relations in Last Chance Canyon

15. North wall of Wilson Canyon

16. Photomicrograph of dolomite from the Grayburg Formation

17. Surface and well sections showing correlation of the Grayburg and Queen Formations .

18. Photomicrograph of fusulinid coquina from the Seven Rivers Foi'mation....

19. Photomicrograph of pisolitic carbonate from the lower part of the Seven Rivers Formation .

20. Contact between the Yates Formation and the Tansill Formation.....

21. Photomicrograph of well-sorted coarse siltstone from the Yates Formation.

22. Nearly vertical sandstone dike in the Capitan Limestone.

23. Calcareous tufa at Sitting Bull Falls

24. Tectonic map of Guadalupe Mountains region

25. Section $B-B^{\prime}$ across Big Dog Canyon.

26. Incised meanders of Dark Canyon at Serpentine Bends

27. Section $C-C^{\prime}$ through the Capitan Limestone and associated rocks

28. Outline maps of three caves

29. Areas of ground-water availability

\section{TABLES}

TABLE 1. Descriptive data on some caves in the Guadalupe Mountains 


\title{
GEOLOGY OF THE GUADALUPE MOUNTAINS, NEW MEXICO
}

\author{
By Philip T. Hayes
}

\begin{abstract}
The area described, nearly 1,000 square miles, lies in Eddy and otero Counties along the south boundary of New Mexico and includes most of the northern part of the Guadalupe Mountains and a considerable area of plains.

Beneath the mapped area, but not exposed on the surface, are rocks ranging in age from Precambrian to Early Permian. Overlying the Precambrian rocks is the Bliss Sandstone of Ordovician age. The Bliss is overlain by the Lower Ordovician El Paso Formation. The El Paso, in turn, is orerlain, in the eastern part of the area, by a unit which is tentatively correlated with the Middle Ordovician Simpson Group of Oklahoma. Under much of the report area, however, the El Paso is overlain by the Montoya Dolomite of Late Ordovician age. Above the Montoya is the Fusselman Dolomite of Silurian age, which is overlain by a unit that is tentatively correlated with the Percha Shale of Late Devonian age. Above the Percha(?) is cherty limestone of Mississippian age, which is overlain by a unit correlated with the Upper Mississippian Helms Formation. Pennsylvanian rocks in the report area range in thickness from 0 to more than 4,000 feet. Both the lithology and thickness of the Pennsylvanian rocks were influenced by Pennsylranian tectonic movements within the area and are highly variable.
\end{abstract}

Permian rocks of the area are divided from southeast to northwest into three facies: Delaware basin, basin margin, and Northwest shelf. The basin rocks are mainly confined to the subsurface, whereas the basin-margin and shelf rocks are widely exposed. In the basin, the lowest Permian rocks are referred to the Wolfcamp Series. Next above is the Bone Spring Limestone assigned to the Leonard Series. The Bone Spring is overlain by the Brushy Canyon, Cherry Canyon, and Bell Canyon Formations of the Delaware Mountain Group which is assigned to the Guadalupe Series. Overlying the Delaware Mountain Group is the Castile Formation of the Ochoa Series. A solution breccia which was mapped with the upper part of the Castile Formation probably represents the Salado Formation. This breccia is overlain by the basal part of the Rustler Formation of the Ochoa Series, the youngest Permian formation in the area.

In the basin-margin area, the Wolfcamp Series is represented by a broad transition zone in which rocks of the basin facies grade into all but the uppermost part of the Hueco Limestone of the Northwest-shelf area. The Leonard Series in the basinmargin area is represented by the Victorio Peak Limestone and Cutoff Shale. An unconformity representing Brushy Canyon time separates the Cutoff from the overlying shelfward-projecting sandstone tongue of the Cherry Canyon Formation. This tongue is overlain by the Goat Seep Dolomite which grades basinward into the Cherry Canyon Formation. The Goat Seep is overlain by the Capitan Limestone. The Capitan is subdivided into a massive member and a breccia member which are transitional into one another both laterally and vertically. The breccia member grades southeastward into the Bell Canyon Formation of the Delaware basin.

In the Northwest-shelf area the lowest Permian formation is the Hueco Limestone. Most of the Hueco is equivalent to basin rocks of the Wolfcamp Series, but the uppermost part may be of early Bone Spring age. Overlying the Hueco is the Yeso Formation which is laterally equivalent to most of the Victorio Peak Limestone. Above the Yeso is the San Andres Limestone. The basal part of the San Andres may grade into the uppermost part of the Victorio Peak; part of it grades into the Cutoff Shale. The medial part of the San Andres apparently has no equivalent in the basin-margin area and seems to be equivalent to the Brushy Canyon Formation of the Delaware basin. The uppermost part of the San Andres grades laterally into the sandstone tongue of the Cherry Canyon Formation. Shelf rocks equivalent to the Goat Seep Dolomite are the Grayburg and Queen Formations which are the lower two formations of the Artesia Group. The Queen is overlain by the Seven Rivers, Yates, and Tansill Formations, which are the upper three formations of the Artesia Group and are laterally equivalent to the Capitan Limestone. The carbonate facies of the Artesia Group, near the basin margin, grades laterally northwestward into an evaporite facies within which the five formations are also distinguished.

Fragments of rock remaining from an ancient sinkhole fill in the Castile Formation contain Cretaceous fossils. Conglomeratic sandstone found in the Guadalupe Mountains in sandstone dikes and shallow sink fills also may be of Cretaceous age. Three small igneous dikes constitute the only Tertiary rock exposed in the area. Quatemary deposits include gravel of Pleistocene age, and alluvium and calcareous tufa deposits of Recent age.

The oldest known structural feature in the report area is the buried northwestward-trending Huapache thrust-fault zone of Pennsylvanian age. The southwest side of the zone was uplifted relative to the northeast side intermittently throughout Pennsylvanian time. The resultant relief had a profound effect on Pennsylvanian sedimentation and also seems to have affected Lower Permian sedimentation. During the Permian, the Bone Spring arch formed in the shelf area along the margin of the Delaware basin. This arch strongly influenced Permian deposition. Cenozoic structural features include folds, faults, joints, and unusual linear features in the Castile Formation. Early Cenozoic folding resulted in anticlines and synclines approximately parallel to the trend of the Capitan Limestone. Probably late in the Cenozoic, concurrent with the main uplift of the Guadalupe Mountains, a monocline and closely associated dome were formed over the old Huapache thrust zone. Most of the faulting in the area also occurred during the uplift of the mountains. The faults, all of which are in the western part of the area, are nearly all normal and trend north to northwest. 
The largest faults have stratigraphic displacements of about 800 feet.

The youthful to mature landforms and the drainage of the area are directly related to the structure and character of the underlying rocks, but they may be partly controlled by an old superimposed drainage system. An extensive limestone cave system, which includes Carlsbad Cavern, was developed principally during an earlier erosion cycle and has been partly exhumed by the modern drainage system.

The earliest geologic event indicated in the area is a probable orogeny that occurred relatively late in the Precambrian. During latest Precambrian and earliest Cambrian time, the area was reduced to a peneplane. From very late in the Cambrian Period or very early in the Ordovician until the end of the Mississippian, the area was inundated by several incursions of shallow seas. Faulting and, possibly, folding occurred during the Pennsylvanian Period and affected Pennsylvanian and Early Permian sedimentation. Sinking of the Delaware basin may have begun in the Pennsylvanian Period or somewhat earlier, but its effects on sedimentation within the report area were most pronounced in the Permian. Differences in depositional environments between the Northwest-shelf area and the basin are reflected by facies changes in Permian rocks. While dominantly clastic sediments were being deposited in the basin, dolomite, limestone, siltstone, and evaporites were deposited on the shelf to the northwest. The intervening basin-margin area was at various times the site of lime-bank deposition and barrier-reef growth. Deposition in the basin-margin area was affected by intermittent mild folding. Toward the end of Permian time the waters of the Delaware basin became more saline, thus causing the end of barrier-reef growth at the basin margin. Evaporite deposits filled the Delaware basin, after which evaporites, dolomite, and clastics were deposited over the basin and the adjacent shelf. The area probably remained above sea level from latest Permian time until late in Early Cretaceous time when a shallow sea apparently advanced over the area once again. This sea retreated early in Late Cretaceous time. Late in the Cretaceous Period or very early in the Tertiary Period, the area was affected by broad epeirogenic uplift. Following this uplift, the ancestral drainage of the area was established and cave solution began. The main uplift of the Guadalupe Mountains probably took place late the Pliocene or early in the Pleistocene, and the present geomorphic features have evolved since that time.

Small amounts of oil are produced from the Bell Canyon Formation in the Black River field. Elsewhere, commercial quantities of gas have been discovered in Pennsylvanian rocks in several wells. About $\mathbf{7 0}$ unsuccessful exploratory holes have been drilled in the report area. Most of these are shallow holes drilled in the Delaware basin. Important reserves of oil may be present in the Delaware basin and in the shelf area. Mineral deposits of potential value include gypsum and sodium sulfate. Ground-water availability in the area is variable, depending on local geologic conditions. In some areas, ground water is virtually nonexistent, whereas, in others, considerable quantities of water of fair quality are available at shallow depths.

\section{INTRODUCTION}

\section{PURPOSE}

After the discovery of oil in Permian rocks in Winkler County, Tex., in 1920, petroleum exploration intensified in adjacent parts of western Texas and southeastern New Mexico. Almost immediately unusual stratigraphic complexities were discovered in the Permian rocks. Thus began a long period of stratigraphic investigations, chiefly reconnaissance studies, of the Permian rocks of the Guadalupe Mountains of Texas and New Mexico. Before 1930 some of the complexities began to be resolved as several geologists almost simultaneously recognized the great barrier reef of Capitan age which separates rocks of radically different character. To the northwest is a great sequence of rocks deposited on a platform area, whereas to the southeast lie the rocks of the Delaware basin. The relations of the basin rocks to the rocks of the reef zone were lucidly described by P. B. King $(1942,1948)$, but confusion and differences of opinion continued about the relations of the shelf rocks to their correlatives in the basin. The present investigation is an attempt, by means of detailed areal mapping, to resolve the relations of the shelf-rock units to one another and to the reef and basin rocks and to clarify the confusing stratigraphic nomenclature.

\section{PREVIOUS WORK}

The first geologist to visit the Guadalupe Mountains was G. G. Shumard (1858), who in 1854, as a member of Capt. John Pope's railroad survey party, examined the part of the mountains that lie in Texas. Fossils collected by Shumard were recognized by his brother, B. F. Shumard (1858), as resembling those of the Permian System in Europe. The next geologist to report on the Guadalupes was Jenney $(1874$, p. 27$)$, who expressed his belief in a Carboniferous age for the rocks exposed there. In 1890 Tarr (1892) visited the Guadalupes in Texas and New Mexico, and he expressed the same opinion. In 1901 Girty $(1902,1908)$ made the fossil collections which were the basis of his report on the Guadalupe fauna and which established the Permian age of the rocks of the southern Guadalupe Mountains. Richardson (1910) and Beede (1910) reported further on the part of the mountains that lie in New Mexico. Baker (1920) first recognized the Yeso Formation and San Andres Limestone there. His report was followed by that of Darton and Reeside (1926) who made the first geologic observations in Last. Chance Canyon.

The second phase of geological study in the Guadalupe Mountains began as a result of interest created during the development of oil fields in Permian rocks to the northeast. The results of field conferences of petroleum geologists and reconnaissance studies of individual geologists were published in papers by Lloyd (1929), Crandall (1929), Blanchard and Davis (1929), and Cartwright (1930). These papers led to a better 
understanding of the facies relationships, but they still left many questions unanswered. Fiedler and Nye (1933), as a result of a ground-water study north of the Guadalupe Mountains, introduced new names for rocks in the shelf area, and more nomenclatorial additions and changes were made by Lang (1937). Numerous papers based on reconnaissance studies of the Guadalupe Mountains or detailed studies in limited areas of the mountains were published in the next decade. All of these contributed valuable information and worthwhile ideas, but it was P. B. King (1942, 1948) who first presented the results of a detailed mapping project in a critical area. His publications clearly describe the stratigraphic relations of the rock units of the Delaware basin to the reef zone in the Guadalupes in Texas. Of the many interesting papers published since 1948 on various aspects of the geology of the Guadalupe Mountains, the most outstanding has been the detailed paleoecologic study by Newell and others (1953) on the rocks of the reef complex. The work of Boyd (1958), and Motts (1962), and the present investigation have produced the first published detailed geologic maps of the Guadalupe Mountains in New Mexico.

\section{PRESENT INVESTIGATION AND ACKNOWLEDGMENTS}

This report is based on fieldwork done intermittently between 1952 and 1957. Geology of the Carlsbad Caverns East quadrangle was mapped in the summer of 1952 during which time Bennett T. Gale, geologist of the U.S. National Park Service, assisted on several occasions. R. L. Koogle assisted in the mapping of the Carlsbad Caverns West quadrangle in the spring of 1955. The rest of the mapping was done in the spring and summer of 1956. The late Jerry Doty assisted in the mapping for 6 weeks and R. L. Harbour for 2 weeks. Brief periods were also spent in the field on several other occasions. On one of these, Curt Teichert aided in measuring stratigraphic sections, and on another, G. O. Bachman gave similar aid. On another occasion George W. Moore and personnel of the National Park Service assisted in the mapping of caves. Geologic mapping was done on vertical aerial photographs of various scales and was transferred to the topographic base, primarily by inspection after elevations of points on contacts were determined by altimeter or hand level. Supplemental mapping of small local areas was done by planetable. Stratigraphic sections were measured on relatively steep slopes by clinometer and tape. The mapping of caves was done by Brunton compass and tape traverses. Personnel of the U.S. National Park Service were helpful on many occasions during the course of fieldwork in Carlsbad Caverns National Park. Property owners throughout the mapped area were most courteous in allowing access to their property, and many gave valuable information concerning water wells and springs.

Besides the fieldwork this report is based on considerable laboratory work, including the microscopic examination of more than 55,000 feet of samples taken from oil wells and test holes drilled in the area. Many of these samples, as well as sample logs, drillers' logs, and data on formation depths, were furnished by oil companies, independent operators, and the New Mexico Bureau of Mines and Mineral Resources. In addition, more than 200 thin sections and 25 polished sections of carbonate rocks were examined. The thin sections were prepared by Nathaniel Taylor; James Thomas determined the magnesium content of 83 carbonate rocks.

\section{GEOGRAPHY}

The area herein described lies in Eddy and Otero Counties along the south boundary of eastern New Mexico. The area is irregular in outline, but it consists of nearly 1,000 square miles which lie entirely between lat $32^{\circ} 00^{\prime}$ and $32^{\circ} 30^{\prime} \mathrm{N}$. and long $104^{\circ} 15^{\prime}$ and $105^{\circ} 00^{\prime}$ W. (fig. 1).

Included in the area are most of the northern part of the Guadalupe Mountains, part of the nearby Brokeoff Mountains, and a considerable area of plains. The Guadalupe Mountains are basically a dissected and tilted plateau of moderate to high relief. The Brokeoff Mountains consist of a series of north-northwestwardtrending ridges and valleys of moderate relief. The plains areas are characterized by very low to moderate relief. Altitudes above sea level range from a minimum of about 3,220 feet where the Black River crosses the east boundary of the mapped area to 7,444 feet in the Guadalupe Mountains near the south edge of the area (pl. 1).

The climate is semiarid; the average annual precipitation ranges from about 13 inches in the lower elevations to perhaps 20 inches in the highest part of the mountains. Most of the precipitation falls between May and October.

Vegetation is sparse throughout most of the mapped area. Areas at lower elevations exhibit a dry-climate flora typical of the Sonoran life zone, whereas areas at the higher elevations exhibit thin juniper forests and scattered stands of Ponderosa pine typical of the transition or foothills life zone.

More than 90 percent of the area is used for grazing by cattle, sheep, and goats, and less than 1 percent is irrigated farmland. The remainder has been set aside as Carlsbad Caverns National Park.

All parts of the mapped area are readily accessible, and no point is more than 2 or 3 miles from a motor 


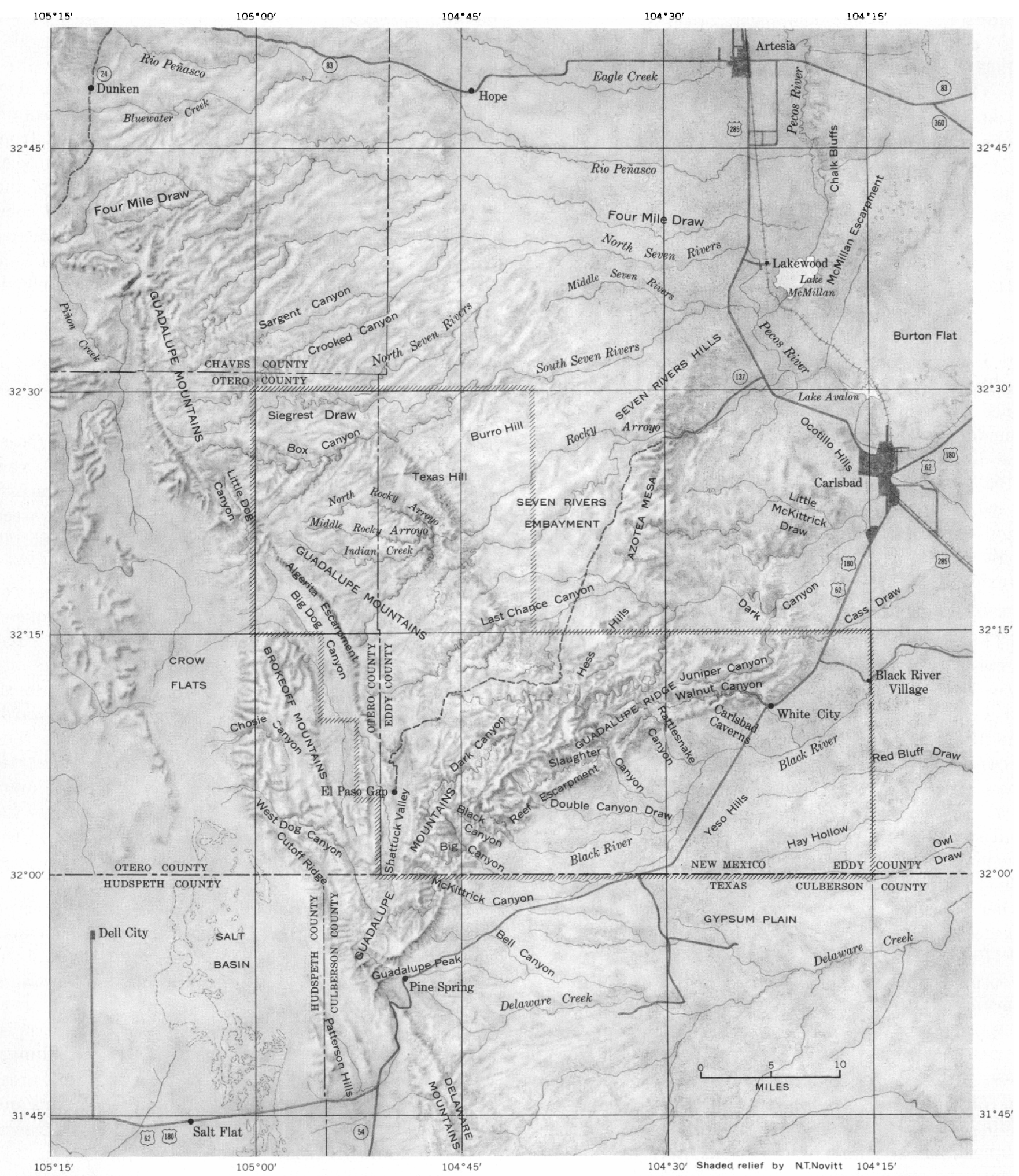

Figdeg 1.--Index map of Guadalupe Mountains region showing location of mapped area, major geographic features, and certain features referred to in text but not shown on the geologie map. 
road. Some of the unimproved roads, however, are suitable only for trucks or four-wheel drive vehicles.

\section{PRE-PERMIAN ROCKS OF THE SUBSURFACE} METHODS OF STUDY

The following description of pre-Permian rocks is based primarily on the examination of samples and sample logs of material from eight wells drilled in, and adjacent to, the geologic map area. For comparison, logs of wells from nearby areas were examined, and outcrops of pre-Permian rocks in the Franklin Mountains, El Paso County, Tex. (fig. 2), were studied and those in other areas were visited.

The methods of study and the terms used for describing well cuttings differ from the methods of study and terms used for description of rocks on the outcrop. For example, the bedding characteristics of rocks in the subsurface cannot be determined, whereas they are an important attribute of rocks exposed on the surface. On the other hand, the color of the rock is not affected by weathering in cuttings as commonly as it is in outcrops.

In the descriptions of subsurface rocks, the following terms and methods of study are used. The Wentworth (1922) scale is used for grain sizes of clastic rocks. Carbonate rocks are termed "coarse-crystalline" if the crystallinity can be seen with the naked eye, "mediumcrystalline" if it camnot be seen without a hand lens or low-powered microscope, and "fine-crystalline" if the crystallinity cannot be seen without high-power magnification. Rock colors are generalized from the National Research Council "Rock-Color Chart" (Goddard and others, 1948). The composition of carbonate rocks was estimated by the degree of effervescence detectable under the microscope when cold dilute hydrochloric acid was applied to the sample. If effervescence was extreme, the sample was called limestone; if there was no effervescence, it was called dolomite. Moderate effervescence indicated dolomitic limestone; slight effervescence indicated calcareous dolomite.

\section{PRECAMBRIAN ROCKS}

Precambrian rocks have been penetrated in three wells drilled in the report areat. In the Humble Oil and Refining Co. Huapache Ínit 2 (sec. 23, T. 23 S., R. 22 E.) the Precambrian cuttings contain a high percentage of quartz and biotite and are interpreted to represent a granitic rock, possibly a granite pegmatite. Precambrian rock found in the Humble Huapache 1 (sec. 35, T. 23 S., R. 22 E.) was reported to be granite also. Both these wells are near the west margin of the Texas craton as delineated by Flawn $(1956, \mathrm{pl} \cdot 1)$ and serve to substantiate the existence of granitic rocks at least as far west as the Guadalupe Mountains. The Precambrian rocks penetrated in the Magnolia Petroleum Co. State "W" 1 (sec. 16, T. 21 S., R. 22 E.) were identified by Flawn (1956, p. 215-216) as chlorite phyllite and metabasalt(?). Apparently all but the northwestern part of the area of this report is underlain by granitic rocks (Flawn, 1956, pl. 1). The highest Precambrian rocks in the northwestern part of the area, according to Flawn (1956, pl. 1), are metamorphosed sedimentary and volcanic rocks.

Exposures of Precambrian rocks nearest to the report area are in the Sierra Diablo, 50 miles to the south (King, P. B., and Knight, J. B., 1944 ; King, P. B., and Flawn, P. T., 1953, p. 71-89), and probably in the Pump Station Hills, about 40 miles to the southwest (King, P. B., 1949; King, P. B., and Flawn, P. T., 1953, p. 123124 ; Masson, 1956, p. 504).

\section{ORDOVICIAN ROCKS}

\section{BLISS SANDSTONE}

The oldest sedimentary unit overlying the Precambrian crystalline basement in the mapped area has been penetrated in three wells and is correlated with the Bliss Sandstone. The Bliss was originally described by Richardson (1904, p. 27) for exposures in the Franklin Mountains, Tex., about 110 miles to the west-southwest. The exposures of the Bliss nearest to the area of this report are in the Baylor Mountains, Tex., about 70 miles south-southwest (King, P. B., 1940, p. 153; King, P. B., and Knight, J. B., 1944), and in the Sacramento Mountains, N. Mex., about 70 miles west-northwest (Pray, 1954, p. 94; fig. 2).

The Bliss Sandstone ranges in thickness from about 23 feet in the Humble Huapache 1 well (sec. 35, T. 23 S., R. 22 E.) to about 100 feet in the Magnolia State "W" 1 (sec. 16, T. 21 S., R. 22 E.). It consists predominantly of light-gray to white rather poorly sorted coarse quartz sandstone at the base and top, separated by mediumgray fine- to medium-crystalline rather sandy dolomite (pl. 2).

The age of the Bliss Sandstone is Early Ordovician. Richardson (1904, p. 27) tentatively assigned a Cambrian age to the formation in the Franklin Mountains. P. B. King (1940, p. 155), on the basis of fossils found near Van Horn and elsewhere, classified the Bliss as Ordovician. Kelley (1951, p. 2203-2205) restated the case for a Late Cambrian age, and Flower (1953, p. 2054-2055) presented new evidence for an Ordovician age of part of the Bliss and concluded that it may range from Late Cambrian to Early Ordovician in age. However, according to Flower (1959, p. 158), only Ordovician fossils have been found in its easternmost 


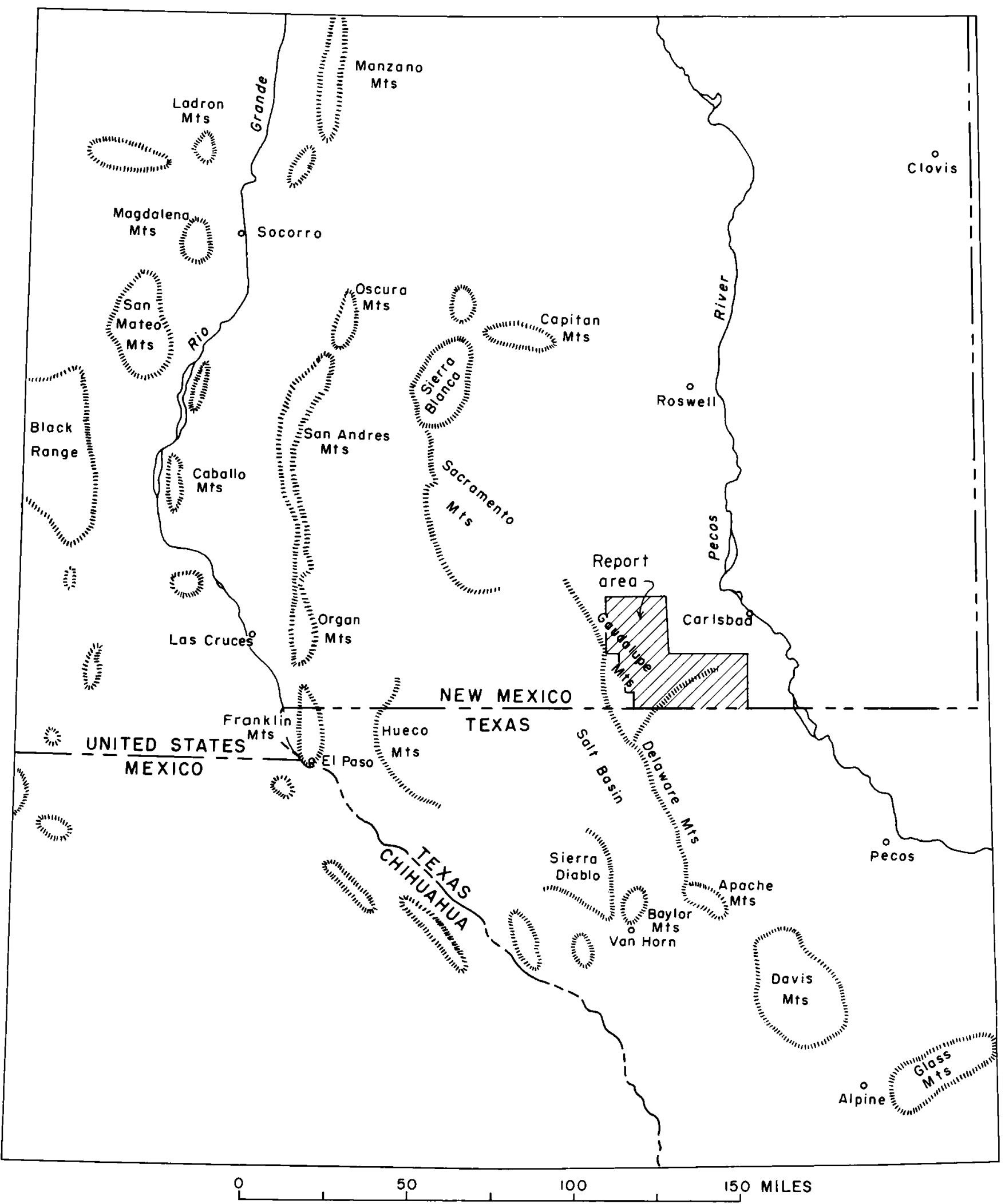

Figure 2.-Map of southeastern New Mexico and nearby areas showing location of mountain ranges referred to in text. 
outcrops; so it is very likely that the Bliss in the subsurface of the report area is entirely Ordovician in age.

\section{el Paso formation}

Overlying the Bliss Sandstone apparently without angular discordance is a sequence of rocks correlated with the El Paso Formation of Early Ordovician age. The El Paso was originally defined and later redefined by Richardson $(1904$, p. $29 ; 1908$, p. 476-479) on the basis of exposures in the Franklin and Hueco Mountains, El Paso County, Tex. The exposures of El Paso Formation nearest to wells in the area of this report are in the Sierra Diablo, Tex. (King, P. B., and Knight, J. B., 1944), about 55 miles to the south-southwest (fig. 2 ). Some workers, especially those whose experience has been primarily with subsurface work in Texas, have used the term Ellenburger Group for the rocks herein referred to as El Paso; but because of the proximity of surface outcrops of the El Paso and close lithologic resemblances, the term El Paso is used in this area. Kelley and Silver (1952, p. 42) proposed raising the El Paso Formation to a group consisting of the Sierrite Limestone at the base and the overlying Bat Cave Limestone at the top. In the mapped area, however, this subdivision cannot be made with any certainty.

The thickness of the El Paso Formation in the report area ranges from 520 feet in the Magnolia State "W" 1 (sec. 16, T. 21 S., R. 22 E.) to 550 feet in the Humble Huapache 2 (sec. 23, T. 23 S., R. 22 E.). The formation consists predominantly of medium-gray fine- to mediumcrystalline generally siliceous dolomite. Slightly sandy dolomite is common especially near the base and top. White to light-gray aphanitic chert is common but not abundant (pl.2).

\section{ROCKS CORRELATED WITH THE SIMPSON GROUP}

Overlying the El Paso Formation in some wells is dark-gray or dark-greenish-gray shale and light-gray, coarse- to fine-grained sandstone, which is tentatively correlated with the Simpson Group of Oklahoma of Middle Ordovician age. The Simpson was originally named by Taff (1902) for exposures in south-central Oklahoma. The term is now widely used for subsurface equivalents in western Texas and southeastern New Mexico (Jones, T. S., 1953, p. 7-10). The nearest exposures of rocks that have been referred to the Simpson are in the Sierra Diablo (Jones, T. S., 1953, p. 7) and Baylor Mountains (West Texas Geol. Soc., 1949, p. 20; Howe, 1959 , p. 2289) about 70 and 85 miles to the south, respectively (fig. 2).

In the Humble Huapache 2 well (sec. 23, T. 23 S., R. 22 E.) the rocks tentatively correlated with the Simpson Group are about 40 feet thick (pl. 2), and in the
Humble Huapache 4-1 (sec. 14, T. 24 S., R. 22 E.) the group is reported to be about 70 feet thick. In the Humble Huapache 3 (sec. 22, T. 24 S., R. 22 E.) equivalent rocks are absent, and they are apparently absent also in the Continental Oil Co.-Standard Oil Co. of Texas Bass 1 (sec. 5, T. 22 S., R. 21 E.). The Simpson equivalent is reported to be 186 feet thick in the Superior Oil Co. Federal 1-134 (sec. 12, T. 26 S., R. 24 E.) in the southeastern part of the report area. About 1 mile east of the report area, in the Humble Wiggs 1 (sec. 31, T. 24 S., R. 27 E.) about 250 feet of rocks are tentatively correlated with the Simpson Group. The western wedge edge of the sequence apparently underlies the report area, and the sequence thickens in an easterly direction at an average rate of nearly 10 feet per mile.

\section{MONTOYA DOLOMITE}

Rocks that are here correlated with the Montoya Dolomite of Late Ordovician age overlie either the El Paso Formation or the rocks correlated with the Simpson Group and have been completely penetrated by six or possibly seven wells in the mapped area. The Montoya was originally named Montoya Limestone by Richardson (1908, p. 476, 478-479) for exposures in the Franklin Mountains, Tex. (fig. 2). On the basis of work in the Caballo Mountains, N. Mex., the Montoya was considered a group by Kelley and Silver (1952, p. 57). The divisions of Kelley and Silver have since been described by Kottlowski and others (1956, p. 23) as members in the San Andres Mountains, N. Mex., about 110 miles to the west. More recently, Howe (1959) has recognized and described several of the subdivisions of the Montoya even closer to the present area in the Sacramento, Hueco, and Baylor Mountains. The nearest known exposures of the Montoya to the mapped area are in the Sierra Diablo, Tex. (King, P. B., and Knight, J. B., 1944) about 55 miles to the southsouthwest (fig. 2).

The basal member of the Montoya in the Caballo Mountains is the Cable Canyon Sandstone (Kelley and Silver, 1952 , p. 58-59). This member is apparently absent in the report area; however, some of the coarse sandstone at the top of the sequence-herein tentatively correlated with the underlying Simpson Group equivalent-may represent an eastern remnant of the Cable Canyon.

The oldest rocks underlying the mapped area that are definitely a part of the Montoya Dolomite are here correlated with the Upham Dolomite (Kelley and Silver, 1952 , p. 59-60), which is now considered a member of the Montoya. Where rocks correlated with the Simpson Group are absent, the Upham Member lies directly on the El Paso Formation and the contact is difficult to 
GEOLOGY OF THE GUADALUPE MOUNTANNS

place. Because of this and becuuse there are apparent structural complications in or near this interval in several wells, the thickness of the Upham can be determined in the Humble Huapache 2 (sec. 23 , T. 23 S., R. 22 E.) only. Here it consists of about 60 feet of medium- to light-gray fine- to medium-crystalline calcareous dolomite (pl. 2). In the Humble Wiggs 1 (sec. 31, T. 24 S., R. 27 E.), just east of the mapped area, the Upham is about 80 feet thick.

Overlying the Upham Member is a distinctive cherty unit correlated with the Aleman Cherty Member of the Montoya Dolomite, formerly called the Aleman Formation (Kelley and Silver, 1952, p. 60-62). The Aleman ranges in thickness from 60 feet to possibly as much as 100 feet and consists of medium- to light-gray finecrystalline dolomite containing 10 to 50 percent or more of white to very light gray porcelaneous chert (pl. 2).

In the Franklin Mountains, Tex., the Aleman Member is overlain by a sequence of rocks which Richardson $(1908$, p. 476) may or may not have included as a part of the Montoya, and which Darton $(1917$, p. 43) included in the overlying Fusselman. Kelley and Silver (1952, p. 62-64) named this unit the Cutter Formation and included it in their Montoya Group. The Cutter is now considered a member of the Montoya Dolomite. The rocks in the mapped area that are correlated with the Cutter Member range in thickness from 95 feet in the Continental Oil Co. East Texas Hill 1 well (sec. 1, T. 22 S., R. 21 E.) to more than 140 feet in the Humble Huapache 2 (sec. 23, T. 23 S., R. 22 E.) and consist of medium-gray fine-crystalline dolomite (pl. 2).

\section{SILURIAN ROCKS}

\section{FUSSELMAN DOLOMITE}

Rocks here correlated with the Fusselman Dolomite of Silurian age overlie the Cutter Member of the Montoya Dolomite with a fairly sharp lithologic break. The Fusselman was named by Richardson (1908, p. $478-480 ; 1909$, p. 4) for exposures in the Franklin Mountains, Tex. The surface exposures of the Fusselman closest to the report area are in the Sierra Diablo, Tex., about 55 miles to the west-southwest (King, P. B., and Knight, J. B., 1944).

In the area of this report the Fusselman consists almost entirely of white to light-gray coarse- to mediumcrystalline dolomite which cont rasts rather sharply with darker colored and finer grained dolomite of the underlying Cutter Member of the Montoya Dolomite. The Fusselman has been completely penetrated by 8 wells in the mapped area and ranges in thickness from about 580 feet in the Continental-Standard of Texas Bass 1 (sec. 5, T. 22 S., R. 21 E.) to about 740 feet in the Humble
Huapache 2 (sec. 23, T. 23 S., R. 22 E.). Just east of the report area in the Humble Wiggs 1 (sec. 31, T. 24 S., R. 27 E.), the Fusselman is apparently 945 feet thick.

\section{DEVONIAN ROCKS \\ PERCha (?) ShaLE}

The Fusselman I olomite is abruptly orerlain in the report area by a sequence of dark-gray, locally silty, shale less than 100 feet thick, which at most place contains a few feet of dark- or medium-gray chert at the base. On the bases of stratigraphic position and lithologr the shale of this unit is tentatively correlated with the Percha Shale of Late Devonian age but some shale of Mississippian age also may be included. The name Percha was given by Gordon (1907, p. 60-62) to exposures along Percha Creek in Sierra County, N. Mex. He assigned a Devonian age to the unit. The name Percha was used by most workers to include all Devonian and possibly the basal Mississippian strata of sonthern New Mexico, until Stevenson (1945) subdivided the strata into several formations and members and restricted the name Percha to the upper part of the original st ratigraphic unit. The dark-gray shale in the subsurface of this area is almost certainly equivalent to some part of the unrestricted Percha as first designated and is more similar lithologically to the restricted Percha as differentiated by Stevenson (1945, p. 241-244) than to any of his older Devonian formations. The chert that is generally present at the base of the darkgray shale is similar in stratigraphic position to a cherty unit of presumed Deronian age of the Sierra Diablo region, Texas (King, P. B., and Knight, J. B., 1944), the Hueco Mountains, Tex. (King, P. B., King, R. E. and Knight, J. B., 1945), and the Franklin Mountains, Tex. (Laudon and Bowsher, 1949, p. 36). Lloyd (1949, p. 46-52) applied the term Woodford to a similar shale and chert sequence found in the subsurface of southeastern New Mexico and correlated it with the Ready Pay Member of the Percha as defined by Stevenson (1945, p. 241-243). Because of the great distance between this report area and the type Woodford Chert of Oklahoma, the term Woodford is not used here.

The Percha (?) Shale and associated chert have been penetrated by 10 wells in the report area; they range in thickness from about 20 feet in the ContinentalStandard of Texas Bass 1 (sec. 5, T. 22 S., R. 21 E.) to about 60 feet in the Humble Huapache 3 (sec. 22, T. 24 S., R. 22 E.). The Percha (?) Shale has a reported thickness of about 100 feet in the Gulf Oil Corp. Estill 1-AD (sec. 29, T. 24 S., R. 26 E.). Just east of the report area the Percha (?) is about 70 feet thick in the Humble Wiggs 1 (sec. 31, T. 24 S., R. 27 E.). 


\section{MISSISSIPPIAN ROCKS}

Above the Percha(?) Shale is a sequence of rocks assigned to the Mississippian System. This sequence can be subdivided into two general units of about equal thickness, a lower cherty limestone unit and an upper shaly unit (pl. 2).

The lower cherty limestone unit consists predominantly of dark- to light-gray fine-crystalline limestone and abundant dark- to medium-gray chert. In most wells minor amounts of dark-gray silty shale and medium- to light-gray calcareous siltstone are present in the unit. The thickness of the unit ranges from about 250 to about 365 feet in the 8 wells in the area which have penetrated it. The unit cannot be definitely related to any known surface formation. It could be equivalent to any or several limestone units of preChester Mississippian age of south-central New Mexico or Trans-Pecos Texas and is here referred to informally as the limestone unit of Mississippian age.

The upper shaly unit of the Mississippian sequence is about half dark-gray shale, much of which is silty; the rest of the unit is mostly medium- to light-gray finecrystalline limestone, and some medium- to light-gray calcareous very fine grained sandstone and siltstone. It is about 200 feet thick in the Humble Huapache 1 well (sec. 35, T. 23 S., R. 22 E.) and Union Oil Co. of California White 1 (sec. 17, T. 24 S., R. 22 E.) ; it is about 254 feet thick in the Humble Huapache 2 (sec. 23 , T. 23 S., R. 22 E.). This shaly unit is correlated with the Upper Mississippian Helms Formation, as restricted by Laudon and Bowsher $(1949$, p. 19) in the Hueco Mountains, Tex. (fig. 2). The nearest known exposures of the Helms Formation are in the Sacramento Mountains, about 70 miles west-northwest (Pray, 1954, p. 99).

\section{PENNSYLVANIAN ROCKS}

Pennsylvanian rocks in the report area range in thickness from 0 to more than 4,000 feet. The lithologic characteristics are variable from place to place. These variations are apparently related to tectonic features of Pennsylvanian age which are discussed in more detail on pages 40-42. Because of vertical repetitions in lithology and lateral variations in lithology and thickness, the Pennsylvanian sequence is not easily divisible on a lithologic basis. However, three major subdivisions with indefinite boundaries can be recognized.

The Pennsylvanian strata of the report area are comparable in a general way to those of northern New Mexico which Read and Wood (1947, p. 223) recognized as constituting a major sedimentary cycle consisting of

(1) a suite of transgressive sediments; (2) evenly and widely distributed marine sediments that were deposited during a yeriod of maximum marine transgression; and (3) unevenly dis- tributed and restricted alternating marine and continental sediments that represent a period of offlap or marine regression.

Where Pennsylvanian strata are present in the mapped area, the basal part, ranging in thickness from about 230 feet in the Humble Huapache 1 well (sec. 35, T. 23 S., R. 22 E.) to more than 400 feet in the Humble Huapache 2 (sec. 23, T. 23 S., R. 22 E.), consists of approximately equal amounts of fine- to coarse-grained poorly sorted locally conglomeratic quartz sanclstone; mottled gray oolitic limestone; and medium- to darkgray shale (pl. 2). These strata are similar in stratigraphic position and lithology to the Sandia Formation of Early Pennsylvanian age of central and northern New Mexico (Herrick, 1900, p. 114-115) and to the lower part of the Gobbler Formation of Pray (1954, p. 93) of the Sacramento Mountains, N. Mex.

Lying gradationally above the basal Pennsylvanian rocks is a sequence of Pennsylvanian strata that varies considerably in thickness and lithology. In general, these rocks consist of varying amounts of medium-gray fine-crystalline locally argillaceous or siliceous limestone and light- to dark-gray locally calcareous or silty shale, minor amounts of dark- to light-gray chert, and a few thin intervals of poorly sorted sandstone (pl. 2). Except in the Continental-Standard of Texas Bass 1 (sec. 5, T. 22 S., R. 21 E.) where strata of Pennsylvanjan age are absent, this unit apparently ranges in thickness from less than 500 feet in the Union White 1 (sec. 17, T. 24 S., R. 22 E.) to more than 3,500 feet in the Humble Huapache 2 (sec. 23, T. 23 S., R. 22 E.).

In most wells in the western part of the area the uppermost strata of Pennsylvanian age are similar to those lying below them, but they contain varying amounts of reddish-brown and greenish-gray shale of possible continental origin. These strata may represent the third phase of the major sedimentary cycle described by Read and Wood (1947, p. 223). They are similar in age and lithology to the Holder Formation of Pray (1954, p. 93; 1959, p. 115-117). Because of Late Pennsylvanian uplift and erosion or nondeposition, these uppermost beds of mixed continental(?) and marine origin are absent in the Humble Huapache 1 well (sec. 35, T. 23 S., R. 22 E.), the ContinentalStandard of Texas Bass 1 (sec. 5, T. 22 S., R. 21 E.), and the wells in the Delaware basin part of the area. Where reddish-brown and greenish-gray shales are present in Upper Pennsylvanian rocks, the systemic boundary between the Pennsylvanian and Permian as based on fusulinid studies is not generally marked by a sharp lithologic change (pl. 2). This situation pertains in the Magnolia State "W" 1 (sec. 16, T. 21 S., R. 22 E.) and in exposures 65 miles to the west near Sand Canyon in the Sacramento Mountains (Bachman and Hayes, 1958, p. 691). 


\section{STRATIGRAPHY OF PERMIAN ROCKS}

\section{FRAMEWORK}

The present report area straddles the northwest margin of the Delaware basin, ${ }^{1}$ one of several sedimentary basins of southwestern United States and northern Mexico which began to form late in Paleozoic time. The Delaware basin reached its maximum depth late in the Permian Period (fig. 3). The Permian rocks of the Northwest shelf, a stable platform area adjacent to the Delaware basin on the northwest, differ markedly in lithology from rocks of the same age in the Delaware basin. A third distinctive facies generally occupies the marginal zone between the shelf and basin facies. In general, the rock units of the basin contain a notably higher proportion of clastic rocks than their equivalents in the shelf area, and the carbonate rocks of the basin have been considerably less dolomitized than the shelf carbonates. The rock units of the basin-margin area contain even fewer clastic beds than equivalent shelf units, but the carbonate rocks of the basin-margin area are intermediate in degree of dolomitization between those of the basin and shelf.

The stratigraphic nomenclature of the Permian System in the Delaware basin is almost entirely different from the nomenclature in the adjacent marginal zone and Northwest-shelf area. The different facies are related to one another by their assignment to one or more time-stratigraphic units, or series (fig. 4). The four provincial series of the Permian System in use in Texas and New Mexico are, from oldest to youngest, the Wolfcamp, Leonard, Guadalupe, and Ochoa (Adams and others, 1939 , p. 1674). All these series are represented in the Guadalupe Mountains area, although rocks of Wolfcamp age are not exposed at the surface. For ease of description the Permian rocks of the Delaware basin are discussed ; this discussion is followed by descriptions of the marginal-zone rocks, and finally by descriptions of the rocks of the Northwest-shelf area. The stratigraphic relations are shown graphically on plate 3 .

\section{ROCKS OF THE DELAWARE BASIN}

The oldest Permian rocks exposed in the Delaware basin in the report area are late Guadalupe in age; the following descriptions of rocks of Wolfcamp, Leonard, and early Guadalupe age in the basin are resumes of published descriptions of those rocks cropping out to the south in Texas, with brief additional notes on their characteristics as determined from nearby drill holes. Rocks of Ochoa age crop out extensively in the southeastern part of the area, but information from drill holes

\footnotetext{
1 Originally called the Delaware Mountain Basin by Willis (1929, p. 1034).
}

is more useful in their description than that obtained from surface studies.

\section{WOLFCAMP SWRIDS \\ WOLFCAMP (?) FORMATION}

Rocks of Wolfcamp age in the northern part of the Delaware basin are tentatively assigned to the Wolfcamp Formation of the Glass Mountains in Texas as described by Udden (1917, p. 41) and redefined by P. B. King (1934, p. 727-730). The type Wolfcamp Formation, however, contains a much higher percentage of shale than rocks of the Wolfeamp Series in the northern part of the Delaware basin. P. B. King (1948, fig. 12) used the term Hueco Limestone for the Wolfcamp rocks of the Delaware basin, but because of rather pronounced differences in lithology, it seems preferable to restrict the term Hueco to the approximately timeequivalent rocks of the Northwest-shelf area (fig. 4).

Three drill holes in the Delaware-basin part of the report area have been drilled through the Wolfcamp Series. The series is reported to be 1,490 feet thick in the Union Crawford 1-26 (sec. 26, T. 24 S., R. 26 E.) and 1,730 feet thick in the Gulf Estill 1-AD (sec. 29, T. 24 S., R. 26 E.). In the Humble Wiggs 1 (sec. 31, T. 24 S., R. 27 E.) about 1 mile east of the mapped area, the Wolfcamp Series is about 1,750 feet thick. It consists of about equal amounts of gray, black, or brown shale, and fine-crystalline rarely cherty brownish limestone. A few thin beds of fine-grained gray micaceous and calcareous sandstone are also present. The upper part of the Pennsylvanian sequence is missing in this part of the Delaware basin, and the basal contact of the Wolfcamp Series is an easily recognized unconformity.

\section{LEONARD SERIES BONE SPRING LIMESTONE}

The Leonard Series in the Delaware-basin part of the report area is represented by the Bone Spring Limestone. Originally named the Bone Canyon Member of the Leonard Formation by P. B. King and R. E. King (1929, p. 921-922) and the Bone Springs Limestone by Blanchard and Davis (1929, p. 962) for exposures in the southern part of the Guadalupe Mountains in Texas, the name was changed to Bone Spring Limestone by P. B. King (1934, p. 731).

In the Union Crawford 1-26 (sec. 26, T. 24 S., R. 26 E.) and the Gulf Estill 1-AD (sec. 29, T. 24 S., R. $26 \mathrm{E}$.), both in the Delaware-basin part of the report area, the Bone Spring Limestone has reported thicknesses of 3,125 and 3,110 feet, respectively, whereas in the Humble Wiggs 1 (sec. 31, T. 24 S., R. 27 E.) just east of the report area, it is apparently nearly 3,400 


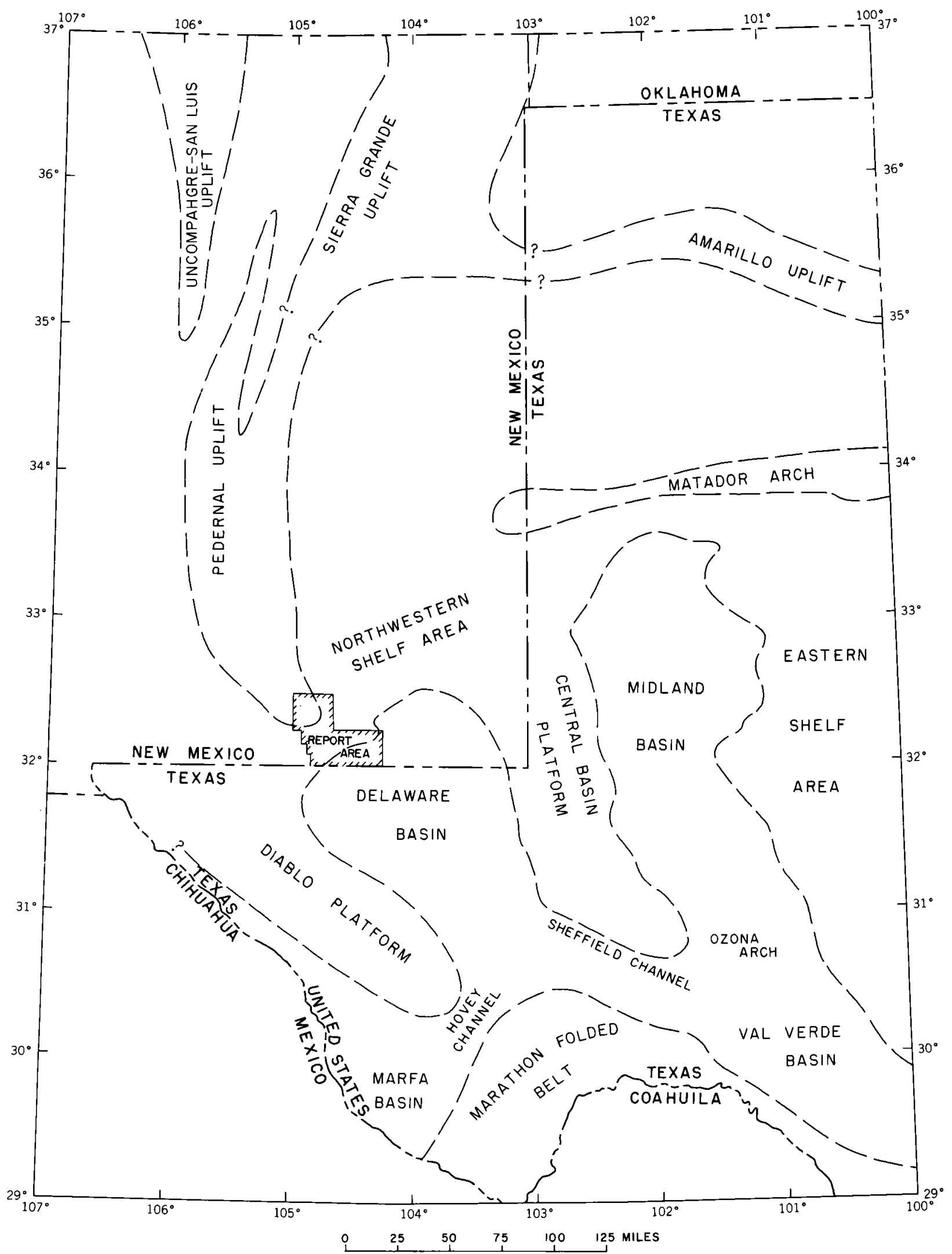

Figdre 3.-Map of western Texas and eastern New Mexico and adjacent areas showing approximate positions of some sedimentary basins and uplifted areas that were prominent during Penosylvanian and Permian time. Map was compiled from various published and unpublished sources. 


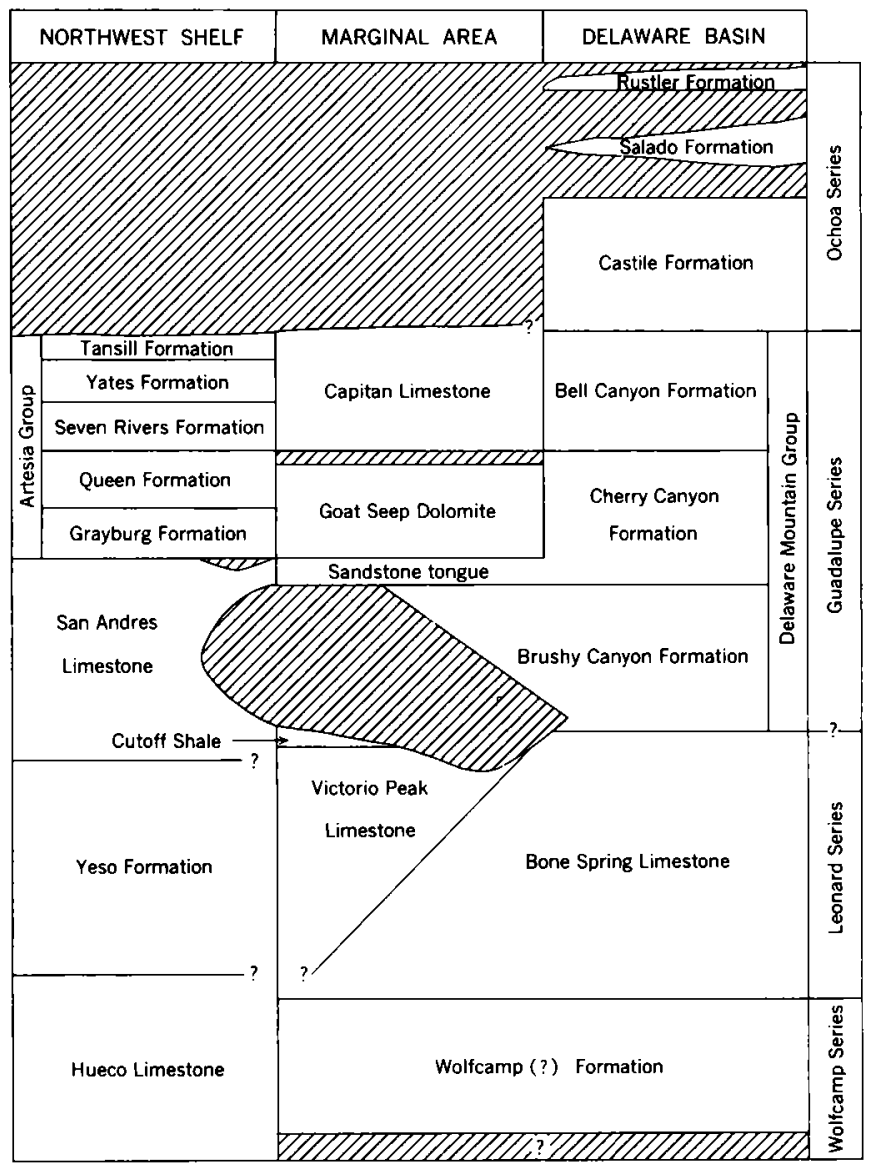

Figdre 4.-Diagram showing correlation of Permian rock units in Guadalupe Mountains region. Diagonal-lined areas indicate rocks are absent.

feet thick. In the Magnolia Homer Cowden 1, 10 miles south of the report area in Culberson County, Tex., the Bone Spring is apparently slightly less than 3,000 feet thick. The formation consists predominantly of brownish-gray fine-crystalline rarely cherty limestone, nearly black to dark-brown shale, and dark-brown shaly limestone. Brownish-gray fine-grained sandstone is abundant in 3 intervals, but it comprises little more than 10 percent of the formation as a whole. As determined from 3 chemical analyses reported by P. B. King (1948, p. 14) and 11 spectrographic analyses and 1 chemical analysis reported by Newell and others (1953, p. 54, 61, $100)$, the black limestone of the Bone Spring has an a verage calcite-dolomite ratio of $79: 21$. Of the samples analyzed, 7 are classified as limestone, 7 as dolomitic limestone, and 1 as dolomite. The 15 samples had an average insoluble residue of 18 percent. Most of the residue consists of silica, but clay minerals and organic material are present.

The Bone Spring Limestone of Leonard age and the underlying rocks of the Wolfcamp Series are lithoJogically similar and could be considered a single for- mation. The contact of the Bone Spring Limestone is arbitrarily placed at the base of the lowest thick sandy sequence. On the basis of fusulinids, some paleontologists agree with this choice of lithologic contact, whereas others place it on top of the lowest sandy sequence, about 500 feet higher.

\section{GUADALUPE SERIES DELAWARE MOUNTAIN GROUP}

In the Delaware basin the Guadalupe Series is represented by the Delaware Mountain Group made up of the Brushy Canyon, Cherry Canyon, and Bell Canyon Formations in ascending order. Richardson (1904, p. 38 ) originally named the Delaware Mountain Formation. The formation was raised to group status by P. B. King (1942, p. 575), who first described its constituent formations (p. 577-586).

At the base of the Brushy Canyon Formation is a persistent unit as much as 150 feet thick, composed of dark-gray to black shale and shaly sandstone interbedded with limestone and sandstone. King (1948, p. 16) earlier included this unit with the underlying Bone Spring Limestone and tentatively correlated it with the Cutoff Shale of the basin-margin area, but on the basis of its lithology and additional fossils found in the unit by Newell and others $(1953$, p. 23$)$, the unit is here included as the basal part of the Brushy Canyon (King, P. B., 1964). Warren (1955, p. 11) referred to the unit as the Pipeline Shale.

At its type locality a few miles south of the present report area the Brushy Canyon Formation above the basal shaly unit consists of 1,000 feet of resistant lenticular coarse-grained sandstone beds separated by less resistant thinner bedded fine-grained standstone (King, P. B., 1942, p. 578-579). A few thin beds of sandy gray or gray-brown limestone are present. Six spectrographic analyses (Newell and others, 1953, p. 54) show that these limestone beds have an average calcite-dolomite ratio of $73: 27$ which classifies them as dolomitic limestone. All the samples were high in silica and alumina; carbonate comprised little more than half of the average sample. As P. B. King (1942, p. 587-588) has demonstrated, the Brushy Canyon has no timeequivalent unit in the basin-margin area (fig. 4). Instead, it overlaps onto the arched beds of the underlying Bone Spring Limestone on the Bone Spring monocline (pl. 3).

The Cherry Canyon Formation conformably overlies the Brushy Canyon Formation. At outcrops near the south end of the Guadalupe Mountains in Texas, the Cherry Canyon is about 1,000 feet thick and consists largely of fine-grained sandstone, but it has several named limestone members. These are, from oldest to youngest, the Getaway, South Wells, and Manzanita 
Limestone Members (King, P. B., 1942, p. 580-581). The Getaway is generally strongly calcitic as determined by five chemical analyses reported by P. B. King $(1948$, p. 35) and on 1 spectrographic analysis reported by Newell and others (1953, p. 62). Of these, 5 samples are limestone and 1 is dolomite; the average calcitedolomite ratio is $80: 20$. A single chemical analysis (King, P. B., 1948, p. 36) of the South Wells shows a calcite-dolomite ratio of $5: 95$, thus determining the sample to be dolomite. The Manzanita is recognized as being strongly dolomitic on the basis of 2 chemical analyses (King, P. B., 1948, p. 37) and 1 spectrographic analysis (Newell and others, 1953, p. 62); it has an average calcite-dolomite ratio of $3: 97$.

The part of the Cherry Canyon Formation beneath the Getaway Limestone Member extends northeastward across the basin-margin area and grades laterally into the upper part of the San Andres Limestone in the Northwest-shelf area (Boyd, 1955, p. 50; 1958, p. 24-27; Hayes, 1959, p. 2204-2205). The part of the Cherry Canyon between the base of the Getaway and the top of the South Wells grades northeastward into the Goat Seep Dolomite of the basin margin (King, P. B., 1942, p. 588). The part of the Cherry Canyon above the South Wells Limestone Member pinches out over the Goat Seep Dolomite (p. 588). These relations are illustrated on the stratigraphic diagram (p. 3).

The Bell Canyon Formation conformably overlies the Cherry Canyon Formation. Near its type locality a few miles south of the present report area, the Bell Canyon Formation is 700 feet thick (King, P. B., 1942, p. 581). It is similar in lithology to the Cherry Canyon and contains five named limestone members separated by thicker intervals of sandstone. From base to top these limestone members are the Hegler, Pinery, Rader, McCombs, and Lamar. The McCombs was named by Newell and others (1953, fig. 6) and formally defined by P. B. King and N. D. Newell (1956, p. 386-387); the Lamar was named by Lang (1937, p. 874-875); the other limestone members of the Bell Canyon Formation were all established by P. B. King (1942, p. 582-58:3). In contrast to the limestones of the upper part of the Cherry Canyon, all limestones of the Bell Canyon seem to be strongly calcitic. Based on 6 chemical analyses reported by P. B. King (1948, p. 55-58) and on 2 versenate analyses made for the present report, the limestones of the Bell Canyon show an average calcite-dolomite ratio of $93: \bar{\tau} ; \bar{\tau}$ samples are limestone and 1 dolomitic limestone.

The Bell Canyon grades laterally northwestward into the Capitan Limestone of the basin margin. The transition is accomplished by thickening of the limestone members of the Bell Canyon, gradation of many sandstone beds of the Bell Canyon into limestone of the
Capitan, and by pinching-out of some sandstone beds of the Bell Canyon (King, P. B., 1942, p. 590-591). P. B. King (1948) and Newell and others (1953) have presented detailed descriptions of the lithologic characteristics and facies changes of the formations of the Delaware Mountain Group in adjacent areas of Texas.

The only. part of the Delaware Mountain Group exposed in the present report area is the top part of the Bell Canyon Formation which crops out discontinuously in low areas southenst of the Reef Escarpment near the New Mexico-Texas State line. The outcrops are of thinly and irregularly bedded dark-gray very fine grained bituminous limestone of the Lamar Limestone Member (fig. 5) overlain by about 5 feet of very thin bedded siltstone and flaggy limestone at the top of the Bell Canyon. In sec. 34, T. 26 S., R. 22 E., these rocks are overlain with apparent conformity by thinly laminated brownish-weathering limestone at the base of the Castile Formation. A small isolated outcrop of thinbedded limestone, probably the McCombs or Pinery Member of the Bell Canyon, grades into the Capitan Limestone at the mouth of Black Canyon.

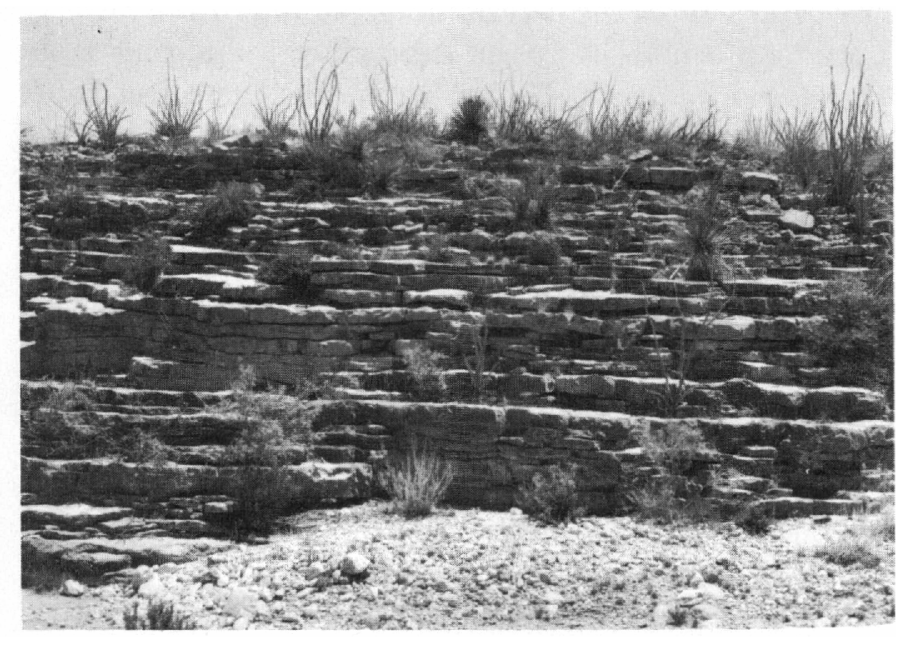

Figure 5.-Thin-bedded dark-gray limestone near top of the Lamar Limestone Member of the Bell Canyon Formation in sec. 34, T. 26 S., R. 22 E. About $1 \frac{1 / 2}{1 / 2}$ miles to the northwest the Lamar Member grades into the breccia member of the Capitan Limestone.

No fossils were collected from the Bell Canyon Formation during the present investigation. P. B. King (1948, p. 69-75) summarized existing paleontologic knowledge of the formation, and Newell and others (1953, p. 227-232) presented lists of fauna collected from the formation. Skinner and Wilde (1954, p. 435$436 ; 1955$, p. 928-929) have since described four new species of fusulinids from the Lamar Limestone Member and one from the McCombs Limestone Member.

The Delaware Mountain Group has been completely penetrated by three drill holes in the report area. The reported thicknesses of the group in those wells range 
from 3,408 feet in the Union Crawford 2-27 (sec. 27, T. 24 S., R. 26 E.) to 3,514 feet in the Gulf Estill 1-AD (sec. 29, T. 24 S., R. 26 E.). Most of the limestone members of the Cherry Canyon and Bell Canyon Formations are thin or absent within a few miles from the basin margin, and therefore the formations of the Delaware Mountain Group cannot be separated easily in the strata penetrated in many wells drilled in the basin. Where fusulinid specimens are sufficiently abundant, the contact of the Bell Canyon with the Cherry Canyon can be rather closely picked inasmuch as the genus Parafusulina, present in the Cherry Canyon, is abruptly replaced by the genus Polydiexodina in the Bell Canyon (Williams, 1953, p. 60). Another possible helpful criterion is the degree of dolomitization of the thin carbonate beds of the two formations: the carbonate beds of the Bell Canyon are all apparently relatively pure limestone, whereas those in the upper part of the Cherry Canyon are generally dolomitic. The stratigraphically highest occurrence of abundant relatively coarse grained sandstone and an almost complete disappearance of carbonate cuttings are probably the best criteria for determining the top of the Brushy Canyon Formation in the subsurface. Judging from these criteria the Bell Canyon is about 860 feet thick at the Humble Wiggs 1 well compared to 700 feet near its type locality; the Cherry Canyon is about 1,300 feet thick at the same well compared to about 1,000 feet in its type area; and the Brushy Canyon thickens from 1,000 feet to about 1,340 feet between its type area and the Humble Wiggs 1.

\section{OCHOA SFRIFB}

Rocks of the Ochoa Series are present only in the Delaware basin in the southeastern part of the area and are represented by the Castile and Rustler Formations. Residual remains of the intervening Salado Formation are mapped (pl. 1) with the Castile.

\section{CASTILE FORMATION}

The Castile Formation was named by Richardson (1904, p. 43) for Castile Spring, 11 miles south of the present mapped area. The formation underlies most of the area of relatively low relief southeast of the Reef Escarpment (fig. 1), but it is partly covered by surficial deposits and small outliers of the Rustler Formation particularly northwest of Black River.

Because dips are low and topographic relief is slight in the area in which the Castile crops out, and because anhydrite in the formation is weathered to gypsum to depths as great as several hundred feet, outcrops do not show the original composition and thickness of the formation.
The basal beds of the Castile Formation can be seen in outcrops in sec. 34 , T. 26 S., R. 22 E., only along the New Mexico-Texas boundary. Here they consist of laminated brownish-gray limestone, a few feet thick, that appears to lie conformably on thin-bedded siltstone and flaggy limestone at the top of the Bell Canyon Formation. These exposures are surrounded by an extensive cover of Quaternary alluvium, and their relations with higher beds of the Castile are not visible.

The lowest part of the Castile in the main outcrop area is exposed on a low west-facing escarpment on the west side of the Yeso Hills from the vicinity of Bottomless Lakes southward beyond the map boundary and in other nearby localities. Here the Castile consists of interlaminated white gypsum and fine-grained darkbrownish-gray limestone (fig. 6).

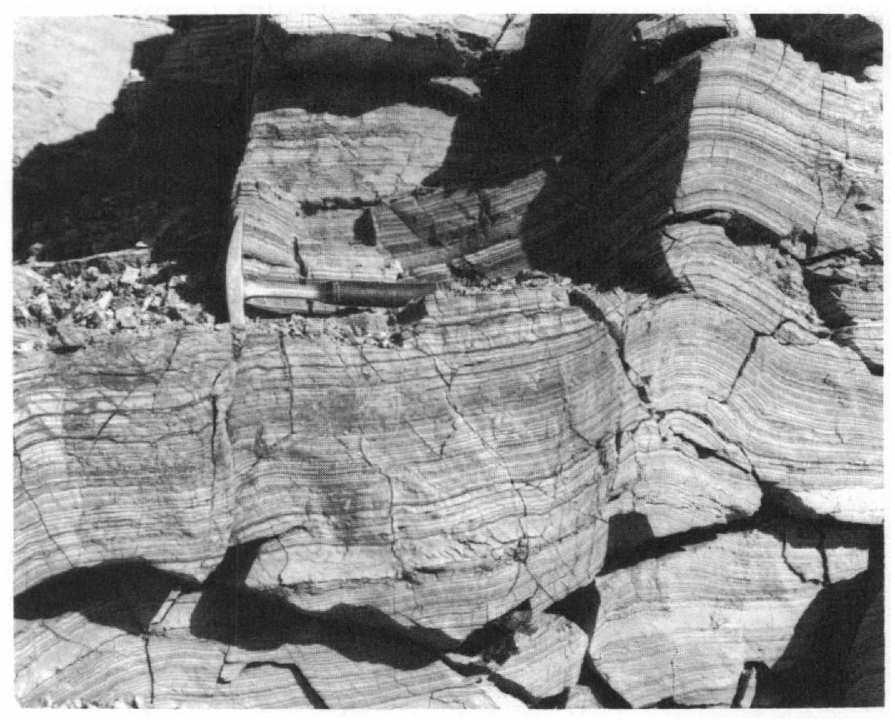

Figdre 6.- Interlaminated white gypsum and dark-brownish-gray limestone in lower part of the Castile Formation in roadeut in $\mathrm{SE}^{1 / 4}$ sec. 28 , T. 26 S., K. 24 E.

Individual laminae generally range in thickness from about $1 \mathrm{~mm}$ to $1 \mathrm{~cm}$. Local beds of fetid laminated limestone as much as about 6 inches thick are present, but generally each lamina of limestone is separated from the next by a lamina of gypsum. Locally, the laminae are sharply contorted into tight miniature folds. P. B. King (1948, p. 91) suggested that the contortion may be related to certain linear features in the Castile Formation. These features are discussed on page 46 of this report.

Overlying the laminated gypsum and limestone is massive fine-grained white gypsum which in the mapped area is by far the most abundantly exposed type of rock in the Castile. Present in the massive gypsum and the underlying laminated part of the Castile Formation in the Yeso Hills are several low isolated mounds of brown locally laminated limestone. Similar, but 
usually more prominent, features present in the Castile Formation to the south in Texas were described by Adams (1944, p. 1606, 1622), who termed them "castiles." Most of these castiles contain considerable limestone breccia in addition to the rather massive and laminated limestone. Adams (1944, p. 1622) suggested that the limestone in the castiles replaced gypsum along fractures that opened during hydration of buried anhydrite, and that the "brecciated appearance is due to fragments falling from the walls of the open passages that were later filled with secondary limestone." Previously, several of these limestone mounds in sec. $12, \mathrm{~T}$. 26 S., R. 24 E., were erroneously mapped as outliers of the Rustler Formation (Hayes, 1957).

The stratigraphically highest beds in the Castile Formation are well exposed on the east bank of Black River in the $\mathrm{NW}^{1 / 4}$ sec. 25 , and the $\mathrm{NW}^{1 / 4}$ sec. 35 , $\mathrm{T}$. 24 S., R. 26 E. The rock consists of reddish-brown claystone, siltstone, and sandstone in much-disturbed beds mixed with numerous blocks and broken beds of gypsum (fig. 7). At many other localities brecciated gypsum with a deep reddish stain and a few blocks of reddish-brown siltstone occur beneath outcrops of the overlying Rustler Formation and in sinkholes in the Castile Formation. Although not mapped separately, these breccias, which make up the uppermost 100 to 150 feet of the Castile Formation, are probably a residuum of the Salado Formation whose thick salt beds were almost entirely dissolved by surface and near-surface solution. The red gypsum may be an alteration product of red anhydrite and polyhalite typical of the Salado Formation in the subsurface to the east. The broken beds of clastic rocks probably are insoluble remnants of the many thin clastic beds known to be

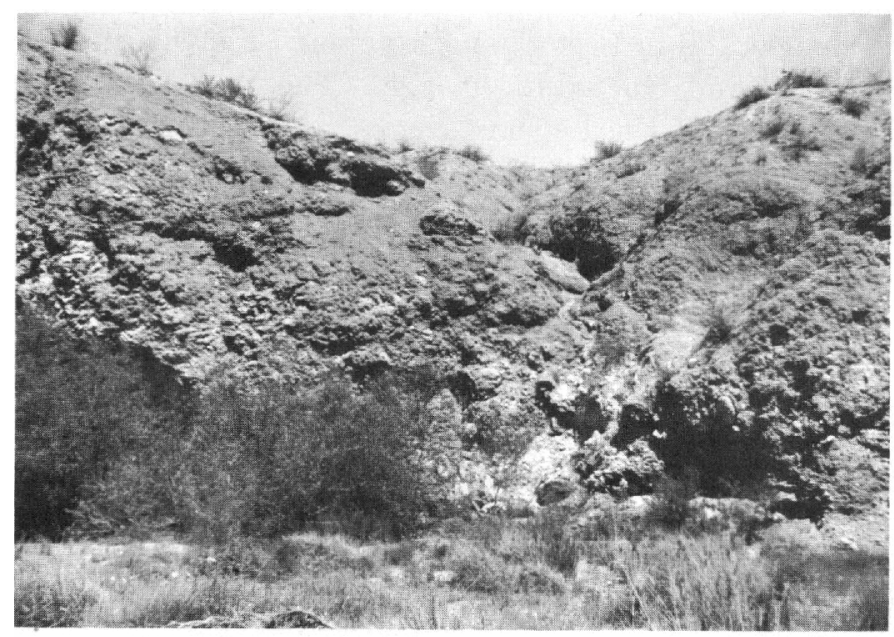

Figdre 7.-Probable residuum of the Salado Formation on the east bank of Black River in the NW $1 / 4$ sec. $35, \mathrm{~T} .24 \mathrm{~S}$., R. $26 \mathrm{E}$. The coarser debris consists of blocks of white and pink gypsum and yellowish-brown and pink siltstone. The matrix is gypsiferous silt. Bank is about 25 feet high. present in the Salado (Adams, 1944, p. 1609-1610). Locally, in gullies above this brecciated unit are relatively undisturbed beds a few feet thick of gypsum and yellowish-brown siltstone. These beds are overlain with apparent conformity by the basal dolomite member of the Rustler Formation. The gypsum and brown siltstone may be equivalent to the basal part of the Rustler Formation as described by Lang (1938, p. 84) and Adams (1944, p. 1614), but it is here considered residuum of the Salado and included with the Castile Formation.

All but approximately the top 125 feet of the Castile Formation was penetrated by the McBride Randel 1 well (sec. 7, T. 26 S., R. 26 E.) which was drilled on the Castile outcrop. In this well the basal part of the formation, about 200 feet thick, is interlaminated white anhydrite and gray to brown limestone. Limestone is dominant in the lower part. Above this is a saline sequence 515 feet thick consisting of 275 feet of halite at the base, overlain by 90 feet of laminated anhydrite and limestone and about 150 feet of halite. A 560-foot sequence of anhydrite containing limestone laminae overlies the saline sequence. At the top is 305 feet of white relatively pure anhydrite overlain by 120 feet of white gypsum, which undoubtedly is a surficial hydration product of anhydrite. Thus, the total original thickness of the formation here was at least 1,825 feet, which conforms closely to the thickness of the Castile in wells farther to the east where the entire formation is preserved.

The Castile Formation is quite uniform in lithology over a wide area in the northern part of the Delaware basin, although thicknesses of individual beds vary considerably. The formation changes markedly, however, near the basin margin as is shown in wells a few miles north of the mapped area. The two units of halite thin abruptly about 2 miles from the basin margin, and the limestone content of the laminated anhydrite units decreases greatly in the same area. Very near the basin margin in the Bauerdorf Schrup 1 well (sec. 4, T. 24 S., R. $26 \mathrm{E}$.) there is no halite and only a trace of limestone in the anhydrite.

The relations of the Castile Formation to rocks of the basin margin are still imperfectly understood. The contact of the Castile with the Capitan Limestone is assumed to be, for the most part, one of sedimentary onlap, but this is not demonstrable at the surface because the contact of the two units is everywhere covered by surficial deposits. Onlap is suggested by two facts: (a) the highest beds of the underlying Bell Canyon Formation apparently are equivalent to beds high in the Capitan Limestone as first suggested by Lloyd (1929, p. 649) and later verified by detailed work of P. B. King (1948, 
p. 60) and Newell and others (1953, p. 47); and (b) in subsurface to the east, the Salado Formation gradationally overlies the Castile in the Delaware basin and overlies the Capitan Limestone and equivalent shelf formations outside the basin. Therefore, the time of deposition of the Castile Formation has been presumed to be represented by a disconformity at the base of the Salado Formation outside the Delaware basin. However, a cross section by Jones (1954, p. 108) based on examination of numerous potash test cores from the Salado suggests that the Salado is transitional into the underlying rocks of the shelf area. Newell and others (1953, p. 47) suggested, with reason, that the basal calcareous beds of the Castile are equivalent to the top of the Tansill Formation of the shelf area. Perhaps, as Jones' cross section suggests, most of the Castile Formation is equivalent to the much thinner Fletcher Anhydrite Member at the base of the Salado Formation in the basin-margin area. Until either a transitional or disconformable contact at the base of the Salado Formation in the shelf area can be verified or until the contact of the Castile Formation with the Capitan Limestone can be seen, possibly by trenching, lateral relations of the Castile must be conjectured.

The Castile Formation apparently contains no fossils. It is assigned to the Ochoa Series of the Permian on the basis of its stratigraphic position.

\section{RUGTLER FORMATION}

The Rustler was named by Richardson (1904, p. 44) for the Rustler Hills, in Culberson County, Tex.

Only the basal part of the Rustler is preserved in outliers in the report area. It consists of less than 40 feet of thin-bedded grayish-pink fine-crystalline dolomite with abundant spherical vugs as much as $1 \mathrm{~cm}$. in diameter, many of which contain residual gypsum (fig. 8).

By the versenate method of analysis, a sample of the dolomite was determined to have a calcite-dolomite ratio of 4:96. These dolomite beds are correlated with the Culebra Dolomite Member which, on the east side of the Pecos River, about 15 miles east of the present report area, is the lowest dolomite in the Rustler (Adams, 1944, p. 1614). In the Rustler Hills of Culberson County, Tex., 28 miles south of the mapped area, several lower dolomite and limestone beds occur in the formation (Walter, 1953, p. 679, 682), but these apparently pinch out before reaching this area.

Along the Pecos River 15 miles to the east, Lang (1938, p. 84) determined a thickness of 500 feet for the Rustler Formation, of which 245 feet lies above the base of the Culebra Dolomite Member. At that locality, more than half of the formation is gypsum and about a

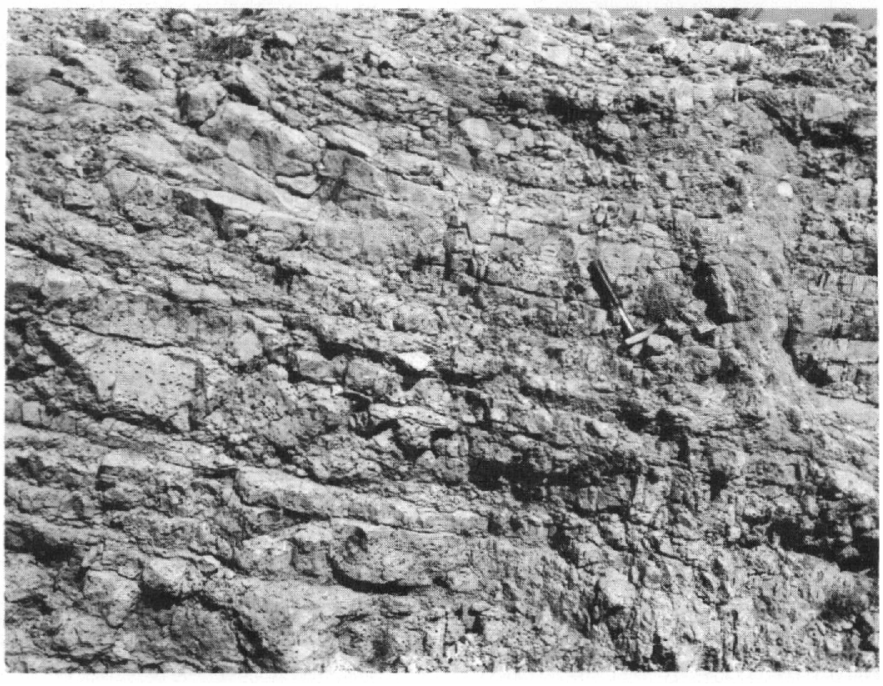

Figure 8.- Thin-bedded dolomite of the Rustler Formation exposed in roadcut in NW1/4 sec. $4, T$. 24 S., R. $26 \mathrm{E}$.

third is red, brown, and gray sandstone and siltstone; persistent and conspicuous beds of dolomite make up the remainder.

Fossils are rare in the Rustler Formation, and none were collected in the report area. Because of the poor fossil record, the age of the Rustler was uncertain for many years. Donegan and DeFord (1950) reviewed previous literature on the subject and reported new fossils from the Rustler Hills which indicated a Late Permian age for the formation. Walter (1953) has since substantiated that age assignment on the basis of his collections in the same general area.

\section{ROCKS OF THE BASIN MARGIN}

Permian rocks of the basin-margin facies crop out between Guadalupe Ridge and the base of the Reef Escarpment and in Last Chance Canyon. These rocks are Leonard and Guadalupe in age. The Wolfcamp and lower part of the Leonard Series in the basin-margin facies have been penetrated at a few places in the area by drilling and are exposed to the south in Texas. Rocks of the Ochoa Series have been removed by erosion from all but the Delaware basin in the report area.

\section{WOLFCAMP SHRIES}

The margin of the Delaware basin apparently was not as well defined during Wolfcamp time as it was during Leonard and Guadalupe times, and no distinctive marginal facies of Wolfcamp rocks has been identified definitely. Presumably, the dark shale and limestone sequence of Wolfcamp age in the Delaware basin grades laterally over a broad transition zone into all but the uppermost part of the lighter colored dolomite and greenish-gray shale sequence of the Hueco Limestone of the Northwest-shelf area. The 1,160 feet of 
rock ascribed to the Wolfcamp Series in the Union White 1 well (sec. 17, T. 24 S., R. 22 E.) apparently represents the shelfward part of this broad transition zone. In this well most of the series is represented by finecrystalline light- to dark-gray dolomite containing minor amounts of gray, brown, green, and black shale, whereas the basal 180 feet or so of the sequence is predominantly light- to dark-gray limestone. The transition between the Hueco Limestone of the shelf and the Wolfcamp rocks of the basin is apparently located farther to the northwest (shelfward) in the basal part of the series than it is in the upper part. There is some suggestion of this in the Union White 1 and a general southeastward migration of the basin margin is well displayed in later Permian rocks of the Guadalupe Mountains.

\section{LEONARD SERTES}

\section{VICTORIO PEAK IIMESTONE}

The Bone Spring Limestone of the Delaware basin grades laterally northwestward into the Victorio Peak Limestone which was originally named the Victorio Peak Massive Member of the Bone Spring Limestone by P. B. King and R. E. King (1929, p. 921) for exposures in the Sierra Diablo. Because it is a distinct mappable unit, the Victorio Peak is now classified as a separate formation (King, P. B., 1964). Relations between the Victorio Peak and Bone Spring of the Delaware basin cannot be observed in the report area, but exposures in the Texas part of the Guadalupe Mountains were described by P. B. King (1948, p. 2627), who wrote:

During the last half of Leonard [Bone Spring] time, the gray Victorio Peak *** was spread out on the shelf area, extending as far southeastward as the edge of the Delaware Basin, where it apparently intergraded with black limestone. During the first half of Leonard time, black limestones extended for several miles farther northwestward toward the shelf, underneath the gray Victorio Peak beds. In the Guadalupe Mountains, exposures of the black limestone do not extend deeply enough to indicate their relations to the shelf area.

Subsurface data indicate that the black limestone beds of the Bone Spring do not extend as far northwest as the Union White 1 well (sec. 17, T. 24 S., R. 22 E.). Instead, they apparently grade northwestward into the light-gray dolomite beds of the basal part of the Victorio Peak Limestone and, possibly, into the uppermost part of the Hueco Limestone, assuming the upper part of the Hueco of the Hueco Mountains is Leonard in age, as has been suggested (King, P. B., King, R. E., and Knight, J. B., 1945; Bachman and Hayes, 1958, fig. 5).

P. B. King $(1948$, p. 17-18, 164) recognized three informal divisions of the Victorio Peak in its exposures on the west side of Cutoff Mountain south of the New
Mexico-Texas State line. The incompletely exposed lower division consists of gray fine-grained somewhat dolomitic limestone in 1- to 6 -foot beds. It contains rare small chert concretions. The middle division, 117 feet thick, consists (p. 18) "of slope-making, thinbedded, light-gray or white limestone, with much buff, fine-grained, calcareous sandstone interbedded." The upper division consists of gray fine-grained limestone in beds as much as 7 feet thick in its basal 217 feet and of thin-bedded limestone in the top 25 feet.

The lower and middle divisions of the Victorio Peak Limestone presumably grade northwestward into the Yeso Formation, whereas the upper division of the Victorio Peak probably grades into the basal part of the San Andres Limestone (pl. 3). The southeasternmost occurrence of gypsum in the Yeso Formation is arbitrarily used as the dividing line between shelf and basin-margin terminology.

\section{CUTOFF SHALE}

Overlying the Victorio Peak Limestone, except where truncated by erosion over the Bone Spring monocline (pl. 3), is the Cutoff Shale. Named the Cutoff Shaly Member of the Bone Spring Limestone by P. B. King (1942, p. 569-570) for exposures on Cutoff Mountain a few miles southwest of the present report area, the unit is now given formational status (King, P. B., 1964). The Cutoff is composed of thin-bedded limestone interbedded with dark siliceous shale, sandy shale, and softweathering sandstone. It is tentatively correlated with the uppermost part of the Bone Spring Limestone or the lowest part of the Brushy Canyon Formation of the Delaware-basin facies and is assigned a Leonard or Guadalupe age or both (Hayes, 1959, fig. 7). The Cutoff grades laterally northwestward through a broad transition zone into part of the main body of the San Andres Limestone. This transition is not exposed in the present report area, but it was described by Boyd (1958, p. 14) 'as occurring in the Brokeoff Mountains a few miles to the west.

\section{GUADALUPE SERIES}

\section{SANDSTONE TONGUE OF THE CHERRY CANYON FORMATION}

The lowest rocks of Guadalupe age in the basinmargin area are included in the sandstone tongue of the Cherry Canyon Formation which disconformably overlies the Cutoff Shale. The Brushy Canyon Formation of the Delaware basin is represented by the disconformity (fig. 4 ; pl. 3). First described by Baker (1920, p. 114) and later by others (Darton and Reeside, 1926, p. 423 ; Crandall, 1929 , p. 935 ; Lang, 1937, p. 859), the sandstone tongue of the Cherry Canyon Formation was named by P. B. King (1942, fig. 7; 1948, p. 38). As 
defined by P. B. King $(1948$, p. 38,47$)$, the tongue is a northward (shelfward) extension of the lower fourth (or sub-Getaway part) of the Cherry Canyon Formation and persists as a layer 200 to 300 feet thick beneath the Goat Seep Dolomite which interfingers with the upper three-fourths of the Cherry Canyon. Boyd (1955, p. $50 ; 1958$, p. 14) later demonstrated the shelfward transition of the sandstone tongue of the Cherry Canyon Formation into the upper part of the San Andres Limestone (fig. 9). ${ }^{2}$

The only exposures of the sandstone tongue of the Cherry Canyon Formation in the report area are in the walls of Last Chance Canyon and in three tributaries in the southern part of T. 23 S., R. 22 E., and the northern part of T. 24 S., R. 22 E. These exposures were correlated with the Cherry Canyon by P. B. King (1942, fig. 7), and this correlation has been generally accepted (Stipp, 1951; Boyd, 1958, p. 26) on the basis of stratigraphic relations, lithology, and fossils.

The tongue is 264 feet thick in Last Chance Canyon near the mouth of Sitting Bull Canyon (stratigraphic section 9, pl. 3). Here it consists of moderately resistant indistinctly bedded grayish-orange very fine grained well-sorted quartz sandstone with scattered irregular chert nodules and silicified megafossils. Some of the chert nodules include abundant silicified fusulinids. The upper 25 to 30 feet of the unit is transitional into an overlying dolomite tongue of the San Andres Limestone. Darton and Reeside (1926, p. 426) listed 35 species of fossils, including 18 different kinds of brachiopods, that were collected from the sandstone tongue of the Cherry Canyon Formation from a locality near stratigraphic section 9 (pl. 3). P. B. King (1948, p. 47-48) and Boyd (1958, p. 61-62) discussed fossils from the unit elsewhere in the Guadalupe Mountain region. No specimens of unreported fossil species were collected from the sandstone tongue of the Cherry Canyon Formation during the present investigation.

\section{GOAT SEEP DOLOMITE}

Gradationally overlying the sandstone tongue of the Cherry Canyon Formation in the basin-margin area is the Goat Seep Dolomite. The Goat Seep is exposed only as an inlier in North McKittrick Canyon near the southwest corner of the mapped area, and neither the base of the formation nor its relations with equivalent rocks of the Delaware basin can be seen. P. B. King

\footnotetext{
2 Boyd believed that the uppermost part of the sandstone tongue of the Cherry Canyon Formation was transitional into the lower part of the Grayburg Formation; but, for reasons discussed on p. 29, I have used an upper boundary for the San Andres Limestone, which is considerably higher stratigraphically than that used by Boyd, thus making the sandstone tongue of the Cherry Canyon equivalent only to part of the San Andres.
}

(1942, p. 588) named the Goat Seep and stated that:

the Getaway and South Wells limestone members of the Cherry Canyon formation thicken northward, and the intervening sandstones disappear *** [the limestone members] coalesce into a solid mass, here termed the Goat Seep limestone ***. The Manzanita limestone member and associated sandstones, which lie above the Getaway and South Wells members, pinch out northward, leaving only a sandy zone between the Goat Seep and the overlying Capitan limestone.

The lower, or Getaway equivalent, part of the Goat Seep is thick bedded and the upper part massive. Although P. B. King (1948, p. 40) extended the name Goat Seep to include equivalent thin-bedded limestones and interbedded sandstones that lie shelfward, Newell and others $(1953$, p. $42-43)$ restricted the term Goat Seep to the massive "reef and forereef talus facies" of the basin margin. This lateral restriction of the Goat Seep was followed by Boyd $(1958, p .15)$ and is used in the present report. Because the Goat Seep consists dominantly of dolomite rather than limestone, it is referred to as the Goat Seep Dolomite here.

The upper 500 feet of the Goat Seep Dolomite is exposed in North McKittrick Canyon. It consists mostly of light-gray massive fine-crystalline to saccharoidal dolomite which at places is very porous and has a wormeaten appearance. Forty-two thin sections of Goat Seep from a stratigraphic section measured at this locality were examined, but the rock has been so thoroughly dolomitized that little primary structure was seen. In some thin sections microbrecciation is visible, and in others, shadowy remnants of unidentifiable fossils are present. A few sections contained as much as 25 percent scattered very fine quartz grains.

Calcite-dolomite ratios of 11 samples of the Goat Seep from the section measured in North McKittrick Canyon were determined by the versenate method. These ranged from $26: 74$ to $3: 97$ and averaged $9: 91$. Of the samples analyzed, 8 are classified as dolomite and 3 as calcareous dolomite. These ratios are similar to ratios of $3: 97$ and $1: 99$ calculated from a previously reported chemical analysis (King, P. B., 1948, p. 40) and spectrographic analysis (Newell and others, 1953, p. 110).

No fossils were collected from the Goat Seep during the present investigation. P. B. King (1948, p. 48-50) summarized earlier paleontologic studies of the formation. Newell and others (1953, p. 227-232) presented a fossil list showing 142 forms from the unit, and Boyd (1958, p. 83) listed a few additional forms. Brachiopods are predominant in the lists. Kenji Konishi (oral communication, 1960), of the Geological Survey, identified the algae Solenopora sp., Mizzia sp., and Gyroporella? sp. and noted unidentifiable forms of stromatolites in thin sections of rocks from North McKittrick Canyon. 


\section{CAPITAN IIMESTONE}

The upper part of the Guadalupe Series in the basinmargin area is represented by the Capitan Limestone which crops out in a continuous band along the Reef Escarpment across the southeastern part of the mapped area. The Capitan was named by Richardson (1904, p. 41) for exposures at the south end of the Guadalupe Mountains, 8 miles south of the present report area. The boundaries of the Capitan were not defined by Richardson, and some early workers apparently included the Goat Seep Dolomite and the bedded carbonate rocks of the Artesia Group of the Northwest shelf in the formation (Girty, 1908, p. 7; Lloyd, 1929, p. 649). Baker (1920, p. 114) recognized that the Goat Seep was a distinct unit and Darton and Reeside (1926, p. 419) separated rocks that are now included in the Artesia Group. The limits of the Capitan as used by Crandall (1929, p. 933, 938) and by Lang (1937, p. 863) have been used by most of the more recent workers (King, P. B., 1948, p. 59; Adams and Frenzel, 1950, p. 296;
Newell and others, 1953, p. 15), and are used in this report. The formation is thoroughly described in the papers cited above, and only some of the general features are given in the present paper.

The oldest part of the Capitan Limestone rests on the underlying Goat Seep Dolomite with an indistinct but apparently disconformable contact. The disconformity represents the uppermost beds of the Cherry Canyon Formation of the basin (King, P. B., 1948, p. 38; Newell and others, 1953, p. 28) and, possibly, the uppermost part of the Queen Formation of the shelf. Within the mapped area, the basal contact is exposed only in the upper part of North McKittrick Canyon. The youngest part of the Capitan has been removed by erosion in the report area, but it is overlapped by evaporite deposits of the Ochoa Series in the subsurface east of Carlsbad. In the report area, the CapitanLimestone grades laterally southeastward into the Bell Canyon Formation and, possibly, into the lowermost beds of the Castile Formation (fig. 9). This transition is incompletely

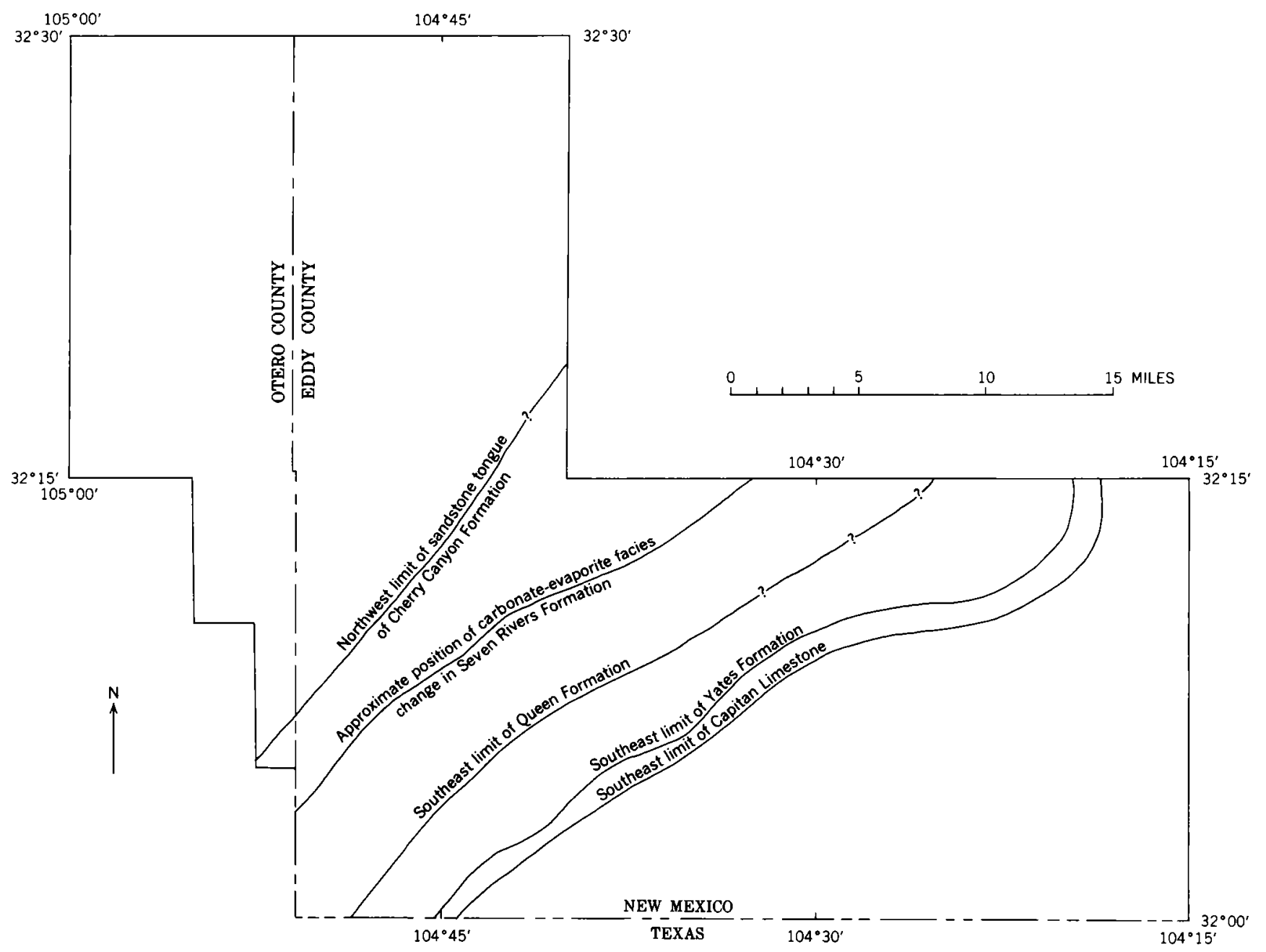

Fiadre 9.-Lateral facles boundaries of some stratigraphic units of Guadalupe age in the report area. 
displayed near the mouth of Big Canyon and can be seen more completely at the mouth of McKittrick Canyon 11/2 miles south of the mapped area. The Capitan grades laterally northeastward into the Seven Rivers, Yates, and Tansill Formations of the Artesia Group, as shown at numerous places within the mapped area.

The Capitan Limestone is divided into two units, a massive member and a breccia member. The two grade into one another both laterally and vertically (fig. 27). common at many localities and are of two ages. Nearly vertical quartz pebble-bearing sandstone dikes near the top of the Capitan in some canyons are clearly of postCapitan age and are discussed on page 37. Irregularly branching dikes as much as several inches thick and isolated pockets contain very fine grained sandstone that is similar in lithology to sandstone in the Yates and Bell Canyon Formations. Sandstone in these irregular dikes and pockets is almost certainly of

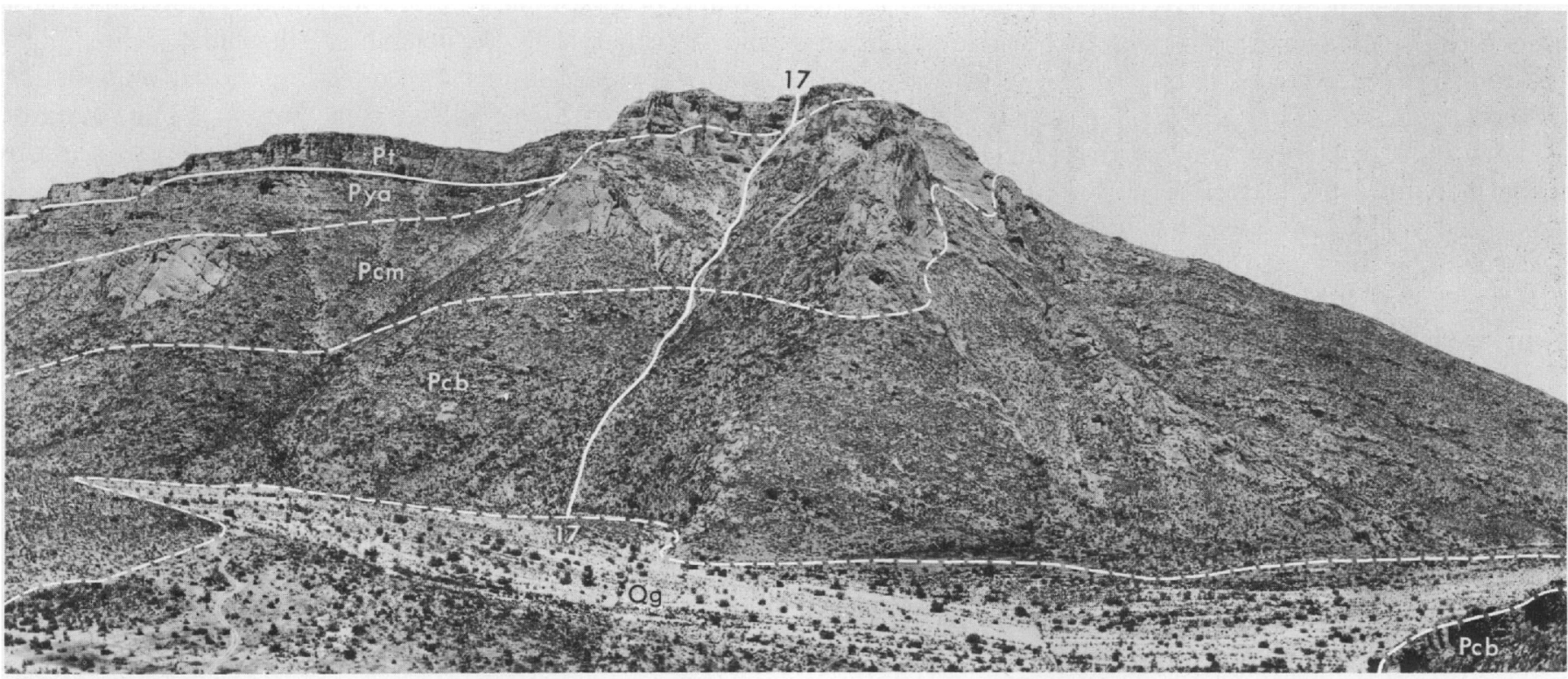

Figure 10.-Northeast side of Slaughter Canyon at location of stratigraphic section 17 . Lateral transition of parts of the Yates (Pya) and Tansill (Pt) Formations into the massive member of the Capitan Limestone (Pcm) and transition of the massive member to the breccia member of the Capitan (Pcb) take place here. Gravel (Qg) covers bottom of canyon.

The gradational contact between these two members rises in stratigraphic position from northwest to southeast and is depicted approximately on the geologic map (pl. 1). The members correspond to the "reef" and "reef talus" facies, respectively, of Newell and others (1953, fig. 24), but descriptive rather than genetic terms for the facies are used in this report.

The massive member of the Capitan Limestone is characterized by a virtual absence of bedding planes. It holds up nearly vertical cliffs in canyon walls from Big Canyon to Slaughter Canyon (fig. 10). It is composed almost entirely of very light gray to yellowishgray fine-textured limestone which weathers light olive gray (fig. 11). Isolated aggregates of white coarsely crystalline calcite are locally common. Calcitedolomite ratios computed from 11 spectrographic analyses reported by Newell and others (1953, p. 110), 2 chemical analyses reported by P. B. King (1948, p. 62), and 2 versenate analyses made during the present work range from $99: 1$ to $84: 16$ and average $96: 4$. Of these samples, $1+$ are limestone and 1 is dolomitic limestone. Sandstone dikes and isolated pockets of sandstone are

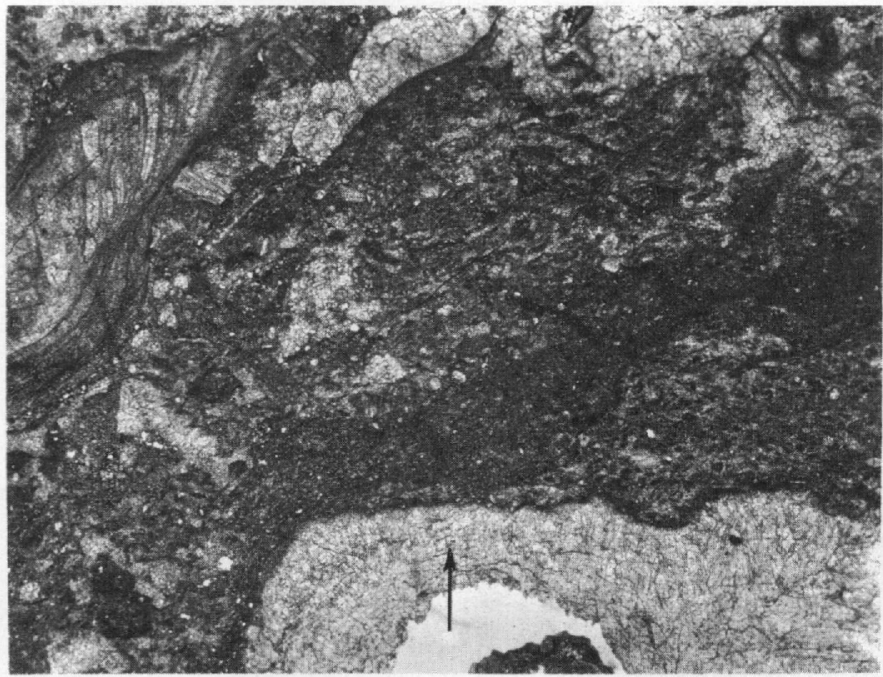

FIGURE 11.-Photomicrograph of limestone from the massive member of the Capitan Limestone. Solution cavity in lower right is partially filled by crystalline calcite which has apparently replaced some of the cavity wall. Most of the rock is flnely divided "lime-mud" which may contain a trace of carbonaceous material. Light areas are autoclusts of limestone within the fine matrix. Fossil at upper left may be part of the brachiopod Prorichthofenia or Leptodus. Arrow $1 \mathrm{~mm}$ long points up. 
Capitan age and apparently fills original voids in the limestone. The dikes rarely extend more than a few tens of feet in any direction, but they are common throughout the massive member. They are especially numerous about half a mile upstream from the mouths of Rattlesnake and Slaughter Canyons.

The massive member of the Capitan Limestone is interpreted to be a reef deposit made up of the remains of marine organisms; however, upon cursory examination it seems to be only sparsely fossiliferous at most places. Solution and recrystallization, surficial weathering, and the very small size of many of the fossils make the fossils difficult to recognize in the field. Small profusely fossiliferous patches of rock can be found, however. One of these is in the upper part of the member on the south side of Yucca Canyon in $\mathrm{SE} 1 / 4$ sec. 28, T. 25 S., R. 23 E. Other fossiliferous patches were seen in West Slaughter and Rattlesnake Canyons. Newell and others (1958, p. 227-232) compiled a list of at least 115 species of fossils from the Capitan. Included are 5 species of fusulinids, 14 species of sponges, 3 species of corals, crinoid remains, 12 species of bryozoans, 46 species of brachiopods, 33 species of mollusks, and 1 species of trilobite. In addition, Johnson (1942) identified six species of fossil algae which apparently were collected from the massive member of the Capitan Limestone, and Newell and others (1953, pls. 17, 18) illustrated three other species of algae not reported by Johnson. Kenji Konishi (oral communication, 1960), of the Geological Survey, examined collections from the Capitan made during the present investigation, and found, besides several species that had been described earlier, specimens of Mizzia sp. from the massive member and Permocalculus? sp. from the breccia member. In all, 3 species of the coralline algae Solenopora, 2 species of the calcareous colonial algae Collenella, and 6 species and 4 genera of green algae have been described from the Capitan. In total volume, stromatolites are probably the most important fossil in the unit, but Newell and others (1953, p. 112) also consider chambered calcareous sponges and other forms as being important "frame-building" organisms.

A transitional contact between the massive member of the Capitan Limestone and the bedded dolomite and sandstone of the upper part of the Artesia Group rises in stratigraphic position from northwest to southeast. Thus, the transition of the base of the Capitan into the basal part of the Seven Rivers Formation is between 2 to 3 miles northwest of its transition into the Tansill Formation. Details of the transition are described in the discussion of the Artesia Group.

The transition of the massive member or "reef rock" of the Capitan into the breccia member or "reef talus" also progresses stratigraphically upward toward the southeast (pls. 1, 3; fig. 9). In vertical sections the thickness of the massive member ranges from about 250 feet to as much as 750 feet and averages about 400 feet (pl. 3).

In the field the breccia member of the Capitan Limestone is distinguished from the massive member primarily by differences in bedding and resistance to erosion. Whereas the massive member is for the most part unbedded, the breccia member is made up of thick beds that dip southeastward $20^{\circ}$ to $30^{\circ}$ or more. The massive member generally holds up nearly vertical smooth-weathering cliffs; the breccia member generally forms ragged slopes (fig. 10). The contact between the two members of the Capitan is vague and is mapped where indistinct bedding planes of the breccia member flatten upward and fade out into the massive member. As much as $5^{\circ}$ to $10^{\circ}$ of the dip in the breccia member probably is due to post-Permian structural movements, but the remainder is depositional.

The breccia member at many places contains coarse angular cobbles and boulders of limestone and dolomite derived from the massive member and from bedded dolomites of the upper part of the Artesia Group. It contains in addition rare fragments of sandstone that may also have been derived from the Artesia Group. Most of the breccia member, however, is microbreccia derived from the same sources (fig. 12). Because it contains both fragments of limestone from the massive member and dolomite from the Artesia Group, calcitedolomite ratios of the breccia member are much more variable than in the massive member. Ratios for 14

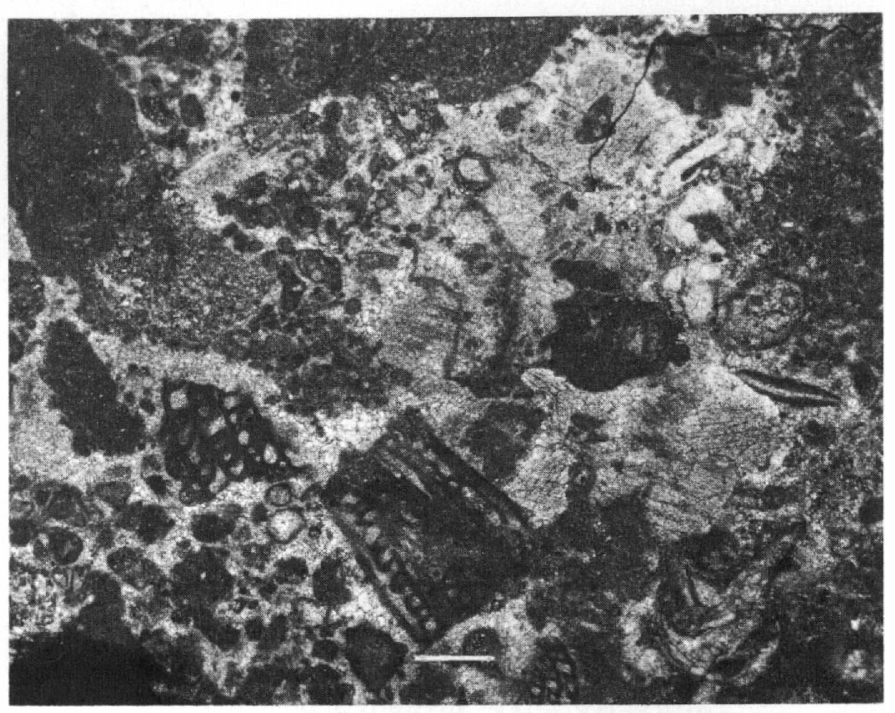

FIgURE 12.-Photomicrograph of limestone from the breccia member of the Capitan Limestone. Note broken fragments of large fusuliaids (probably Polydiexodina) and other organle debris in finely cryatalline calcite matrix. At top are subrounded limestone clasts derived from the massive member. Bar is $1 \mathrm{~mm}$ long. 
calcite-dolomite samples were computed from 2 chemical analyses reported by P. B. King $(1948$, p. 62$), 3$ spectrographic analyses reported by Newell and others (1953, p. 69), and 9 versenate analyses made during the present investigation. These ratios range from $99: 1$ to $2: 98$ and average $60: 40$. Among the samples tested, 3 are limestone, 5 are dolomitic limestone, 4 are calcareous dolomite, and 2 are dolomite.

Basinward transition of part of the breccia member of Capitan Limestone into the Bell Canyon Formation can be observed near the mouth of Big Canyon in the report area. This transition has been described in detail by P. B. King (1948, p. 59-61) and by Newell and others $(1953$, p. 67-69) on the basis of more complete exposures to the south in Texas. The contact between the Capitan and Bell Canyon on the geologic map (pl. 1) represents the disappearance northwestward of sandstone beds of the Bell Canyon into limestone breccia. In the words of P. B. King $(1948$, p. 61$)$ the sandstone disappears "partly by interfingering with numerous limestone tongues and partly by a change into sandy limestone and thence into pure limestone." At approximately the same lateral position a less abrupt change in the bedding, texture, composition, and color of the limestone takes place. Steeply inclined thick beds of light-gray limestone and dolomite of the breccia member become thinner where they flatten out and change to darker gray bioclastic limestone of the Bell Canyon Formation. As was mentioned above, the youngest beds of the Capitan may grade into the basal laminated limestone beds of the Castile Formation, but this cannot be proved by the present exposures. The Capitan to Bell Canyon transition takes place in progressively younger beds toward to southeast.

The maximum vertical thickness of the breccia member measured across its inclined beds without regard to the dip is probably about 1,750 feet, and its average thickness is about 1,250 feet. The breccia member of the Capitan comprises about two-thirds of the total bulk of the formation (pl.3). The maximum vertical thickness of the Capitan Limestone as a whole may reach 2,000 feet in McKittrick Canyon about 1 mile south of the present report area (King, P. B., 1948, p. 61).

A few miles north the Capitan Limestone is covered by younger rocks. Its presence along most of the margin of Delaware basin is established from well data and from outcrops in the Glass and Apache Mountains in Texas.

\section{ROCKS OF THE NORTHWEST SHELF}

Permian rocks of Wolfcamp, Leonard, and Guadalupe age of the Northwest shelf are found in the northwestern part of the report area; rocks of Ochoa age are not preserved. The basal Permian formation of the shelf, the Hueco Limestone, is not exposed at the surface, and the lower part of the overlying Yeso Formation is also buried. The following descriptions of those units are based primarily on subsurface data.

\section{HUECO LIMESTONE}

The oldest rocks of definite Permian age of the shelf facies are assigned to the Hueco Limestone. The term Hueco was originally used by Richardson (1904, p. 3238) for a thick sequence of rocks exposed in the Hueco Mountains, Tex. The sequence later proved to include rocks ranging in age from Devonian to Permian and the name Hueco was formally restricted by P. B. King (1934, p. 742 ) to apply only to Permian rocks. The Hueco is known only in the subsurface of the report area; the nearest surface exposures are 50 miles south in the Sierra Diablo and 55 miles west in the Hueco Mountains (fig. 2). Two distinct members of the formation are recognized in the report area.

Where both are present, the lower member of the Hueco Limestone is lithologically indistinguishable from the uppermost strata of Pennsylvanian age, but they usually can be separated on the basis of the fusulinids present. The lower member of the Hueco is similar in age and lithology to the type Bursum Formation of south-central New Mexico as originally defined by Wilpolt and others (1946) and to the Laborcita Formation of Otte (1959) in the northern Sacramento Mountains (fig. 2), but it is probably not coextensive with either of those units. The member consists of medium-gray fine-crystalline locally siliceous limestone interbedded with reddish-brown, greenish-gray, and gray shale and minor amounts of fine-grained sandstone.

The thickness of the lower member of the Hueco varies considerably over short distances. In the Continental-Standard of Texas Bass 1 well (sec. 5, T. 22 S., R. 21 E.) on Texas Hill, the lower member of the Hueco and the underlying Pennsylvanian sequence are absent. The lower member of the Hueco is apparently present in most wells in the shelf area, however, and reaches a maximum thickness of at least 500 feet in the Magnolia State "W" 1 (sec. 16, T. 21 S., R. 22 E.).

The upper member of the Hueco consists chiefly of medium-gray fine-crystalline dolomite, subordinate greenish-gray shale, and rare grayish-red shale. The proportion of red shale probably increases northwestward toward the Sacramento Mountains where the Hueco grades laterally into red beds of the Abo Sandstone (Pray, 1954, p. 101; Bachman and Hayes, 1958, p. 692).

The thickness of the upper member of the Hueco 
Limestone ranges from about 880 feet in the Continental-Standard of Texas Bass 1 well, where the lower member of the formation and Pennsylvanian rocks are absent, to about 1,330 feet in the Continental East Texas Hill 1 (sec. 1, T. 22 S., R. 21 E.). It is probably even thicker in the Humble Huapache 2 (sec. 23, T. 23 S., R. 22 E.).

Much of the Hueco Limestone is laterally equivalent to rocks of the Wolfcamp Series of the Delaware basin, but the uppermost part is probably equivalent to the basal part of the Bone Spring of Leonard age. This is apparently true in the Hueco Mountains (King, P. B., and others, 1945), and it may also be true in the southern part of the Sacramento Mountains (Bachman and Hayes, 1958, p. 695). Where the upper part of the Hueco Limestone of the shelf grade southeastward into rocks of the basin, the Hueco contains thick fine- to coarse-crystalline dolomite beds which are informally referred to as "Abo reefs" (Podpechan, 1959; LeMay, 1961). These rocks contain large reserves of petroleum in fields to the north and northeast of the report area.

\section{YESO FORMATTON}

The Yeso Formation was named by Lee (1909, p. 12) for exposures on Mesa del Yeso, 150 miles northwest of the present report area. Darton (1922, p. 181) reduced the Yeso to a member of the Chupadera Formation, but it was redescribed and again raised to formational status by Needham and Bates $(1943$, p. $1657-$ 1661).

Rocks assigned to the Yeso Formation in the report area are actually in a transition facies between the Victorio Peak Limestone and the much more gypsiferous Yeso Formation of areas to the north. These transition rocks could just as well be assigned to the Victorio Peak; but where even thin beds of gypsum or anhydrite are present, they are arbitrarily placed in the Yeso.

The upper 600 feet or so of the Yeso Formation crops out on the lower slopes of Algerita Escarpment and is the oldest rock exposed in the report area. The major constituent of the Yeso Formation in these exposures is dark- to light-gray generally slightly fetid dolomite and dolomitic limestone mostly in beds less than 1 foot thick. Two versenate analyses of carbonate samples from the Yeso showed calcite-dolomite ratios of 6:94 and 10:90. Interbedded with the dolomite in about equal amounts are massive white gypsum and thin beds of nonresistant grayish-yellow sandy quartzose siltstone. The percentage of gypsum and siltstone in the Yeso decreases notably from northwest to southeast along the outcrop. At the north end of the outcrop band the top of the Yeso is a bed 8 to 10 feet thick of sandy siltstone which is conformably overlain by rela- tively thick-bedded cherty dolomite at the base of the San Andres Limestone. Toward the south, the siltstone is missing and dolomite of the Yeso Formation is directly overlain by dolomite of the San Andres Limestone. A graphic section of the upper part of the Yeso Formation as it appears in the central part of its outcrop band is shown on plate 3 (stratigraphic section 1).

The sandy siltstone bed that occurs at the top of the Yeso Formation in the northern part of the outcrop was considered by Skinner (1946, p. 1864) to be a southern extension of the Glorieta Sandstone of central New Mexico. However, it appears that the Glorieta pinches out near Sierra Blanca, about 75 miles to the northwest (R. L. Harbour, oral communication, 1958), and because the siltstone bed closely resembles other siltstone beds in the Yeso, it is here included as a part of the Yeso Formation. It is a possible equivalent of siltstone at the top of the Yeso in the subsurface at Dunken Dome, less than 25 miles to the northwest, which Needham and Bates (1943, p. 1660) correlated with the Joyita Sandstone Member of the Yeso.

The thickness of the Yeso varies in wells drilled in the area. In general, the formation is thinnest where the underlying Hueco Limestone is relatively thin, and the Hueco is thinnest over areas where the Pennsylvanian sequence is thin or absent. In the Continental-Standard of Texas Bass 1 (sec. 5, T. 22 S., R. 21 E.) where Pennsylvanian rocks are absent and the Hueco Limestone is relatively thin, the Yeso is about 1,685 feet thick. In the Magnolia State "W" 1 (sec. 16, T. 21 S., R. 22 E.) where both the Pennsylvanian sequence and the Hueco Limestone are relatively thick, the Yeso is about 2,410 feet thick. It is apparently even thicker in the Humble Huapache 2 (sec. 23, T. 23 S., R. 22 E.) where the Pennsylvanian System reaches its maximum thickness in the area. It appears that the crustal movements that affected Pennsylvanian sedimentation were still active in Yeso time. Similar conclusions were drawn by Pray $(1959$, p. 126$)$ on the basis of work in the Sacramento Mountains.

In the subsurface the Yeso Formation consists dominantly of medium- to light-gray fine-crystalline dolomite. In most wells small amounts of white to very light gray anhydrite are present in the upper 200 to 250 feet of the formation. Very light gray coarse quartzose siltstone and very fine grained sandstone occur in many thin layers and in two relatively thick layers, but they make up less than 10 percent of the whole unit. The siltstone sequence at the top of the Yeso noted in outcrops is also a useful subsurface datum. It apparently ranges from as little as 10 feet to more than 60 feet thick. Another thick siltstone and sandstone sequence is 1,150 feet below the top of the Yeso in the 
Continental-Standard of Texas Bass 1 where the formation is 1,685 feet thick. In the Magnolia State "W" 1 , where the formation is 2,410 feet thick, this siltstone occurs 1,830 feet below the top of the formation (pl. 2 ). It is locally at least 100 feet in thickness and probably represents the subsurface Drinkard Sandy Member of R. E. King (1945, p. 13), which he believed was present in a well in sec. 16, T. 21 S., R. 23 E., only 6 miles east of the Magnolia State "W" 1. The Drinkard Sandy Member of King (1945) is stratigraphically too low in the Yeso to be exposed in the report area, and it has apparently never been identified in outcrops. In wells, the Yeso is distinguished from the underlying Hueco Limestone by a lack of greenish-gray and reddish-brown shale and the presence of sandstone and siltstone beds.

Lateral transition of the Yeso Formation into the Victorio Peak Limestone cannot be seen in outcrops; so the precise relation of the two units is unknown. However, because the uppermost part of the underlying Hueco Limestone may be equivalent to the basal part of the Bone Spring, and because, as is described below, the basal part of the overlying San Andres Limestone may be equivalent to the upper division of the Victorio Peak, the Yeso Formation is presumed to be equivalent to all but the youngest and oldest beds of the Victorio Peak.

The Yeso Formation is nearly devoid of recognizable fossils. Dolomitized fusulinids are present in some beds, and Boyd (1958, p. 19) noted crinoid columnals in the Yeso in the El Paso Gap quadrangle at the southern end of the outcrop band in Big Dog Canyon.

\section{GAN ANDRES LIMESTONE}

The San Andres Limestone is widely exposed in the Guadalupe Mountains upland, in and near the Brokeoff Mountains in the northwestern part of the area, and in several inliers, the most important of which is in Last Chance Canyon in the central part of the area. Originally named by Lee (1909, p. 12) for the San Andres Mountains, 100 miles to the west, the San Andres was reduced to a member of the Chupadera Formation by Darton (1922, p. 181), but it was redescribed and reelevated to formational status by Needham and Bates (1943, p. 1664-1666).

The San Andres Limestone is divided into two informal units: a lower cherty member and an upper member. Boyd (1958, p. 23) recognized a similar division in the Brokeoff Mountains (fig. 1), but he was uncertain whether the upper limit of abundant chert defined a single stratigraphic horizon. In Last Chance Canyon the two members are distinctive and are separated by a local unconformity. Farther north and west, however, the contact is apparently conformable and indefinite. Reconnaissance north of the mapped area (Hayes, 1959, p. 2199-2200) indicates that the stratigraphically highest occurrence of abundant chert does not form a consistent regional time datum; it is, nevertheless, a fairly consistent datum in the report area, and it seems to be a useful subsurface datum within 20 or 30 miles north and west of the basin margin. Where the formation is complete, the two members of the San Andres are approximately of equal thickness.

The lower cherty member of the San Andres northwest of the Last Chance Canyon-Rocky Arroyo drainage divide is characterized by variable amounts of rusty-weathering light- to medium-gray chert that generally occurs in irregularly shaped nodules but at some places is found as thin lenticular beds. Many of the chert nodules have indistinct margins and contain patches of dolomite, whereas other nodules seem to consist of pure chert which has sharply defined margins. Chert is most abundant near the top of the member where it locally comprises more than one-fourth of the rock.

The bulk of the lower cherty member in the northwestern part of the area is dolomite and dolomitic limestone. As determined from 8 versenate analyses made during the present investigation and a spectrographic analysis reported by Boyd (1958, p. 24), calcite-dolomite ratios of carbonate rock in the member range from $0: 100$ to $73: 27$ and average $16: 84$. Of the samples analyzed, 5 are classed as dolomite, 3 as calcareous dolomite, and 1 as dolomitic limestone. No systematic lateral variation was noted, but the upper part of the member tends to be slightly more calcitic than the lower part. Carbonate rock in the lower cherty member is generally medium gray and weathers to light olive gray. In general, it is rather thickly and obscurely bedded, but some beds are thin and parallel (stratigraphic section $1, \mathrm{pl} .3$ ). In texture the carbonate rock ranges from fine crystalline to medium crystalline. Most samples are rather homogeneous in texture, but some show medium-crystalline calcite in a much finer dolomite matrix. Vuggy porosity is common but not universal.

Contact of the San Andres with the underlying Yeso Formation is conformable. Along the northern part of Algerita Escarpment it is easily recognized at the top of the highest siltstone bed of the Yeso. To the south the siltstone bed is absent, and the contact between the two formations is arbitrarily placed between relatively thin bedded noncherty slope-forming gray dolomite of the Yeso and the thicker bedded cherty more resistant light olive-gray-weathering dolomite of the San Andres.

Contact between the lower cherty member and the upper member of the San Andres is apparently con- 
formable in the northwestern part of the area. In much of the area, chert is particularly abundant near the top of the lower member and virtually absent in the upper member, making the contact sharp; but in some places the amount of chert gradually decreases upward so that the contact is not so sharply defined.

For purposes of description the upper member of the San Andres Limestone in exposures north and west of the Last Chance Canyon drainage is divided into two approximately equal parts. The lower part consists of deeply pitted fine-crystalline light olive-gray to pale yellowish-brown dolomite and dolomitic limestone in beds 1 to 5 feet thick. It is typified by abundant recrystallized fusulinids and fusulinid molds. Calcitedolomite ratios computed from 1 spectrographic analysis reported by Boyd (1958, p. 24) and from 3 versenate analyses range from $75: 25$ to $9: 91$ and average $32: 68$. The upper part of the upper member is composed of laminated microcrystalline yellowish-gray to light olive-gray dolomite in beds 2 inches to 3 feet thick and of 1 to 3 thin units of fine-grained yellowish-brown sandstone. The slight compositional, textural, and color change between the two parts of the upper member is transitional and vaguely defined. Boyd (1955, p. $50 ; 1958$, p. 22 ) apparently used this change as the contact between the San Andres and the overlying Grayburg Formation, but for reasons mentioned below (p. 29), the upper dolomite is here included with the San Andres (Hayes, 1959, p. 2210-2211).

The thickness of the San Andres Limestone is difficult to determine. The only place where the base and top of the formation are exposed within a reasonable horizontal distance is on Algerita Escarpment in sec. 3, T. 24 S., R. 20 E., where several high-angle strike faults are present. Stratigraphic section 1 (pl. 3) is a composite of partial sections measured in the fault blocks. In this composite section the San Andres is a little more than 1,200 feet thick, and in the Magnolia State "W" 1 well (sec. 16, T. 21 S., R. 22 E.) it is apparently 1,300 feet thick (pl. 2).

The San Andres Limestone in Last Chance Canyon and vicinity and in its southernmost exposures in the Dog Canyon area differs in several respects from the formation to the north. Local unconformities separate the upper and lower members of the San Andres, and the San Andres from the overlying Grayburg Formation. The lower cherty member changes somewhat in lithology southeastward as it approaches the basinmargin area, and the upper member largely completes its transition into the marginal facies.

The lower cherty member in Last Chance Canyon and vicinity is similar in overall appearance to equivalent rocks farther northwest, but it is more irregularly bedded and locally contains several thin layers of thinly bedded grayish-orange-weathering siltstone and silty claystone. Between the mouths of Roberts and Sitting Bull Canyons the beds pinch and swell, and several local angular unconformities and other irregularities are present in the bedding, which suggest deposition in an unstable area (fig. 13). Carbonate rock in the lower cherty member of the Last Chance Canyon area tends to be somewhat more calcitic, finer textured, and siltier than it is to the northwest. As calculated from versenate analyses of 13 samples from sections measured in Last Chance Canyon, calcite-dolomite ratios range from $3: 97$ to $96: 4$ and average $38: 62 ; 6$ samples are classed as dolomite, 2 as calcareous dolomite, 3 as dolomitic limestone, and 2 as limestone. Insoluble residues, con-

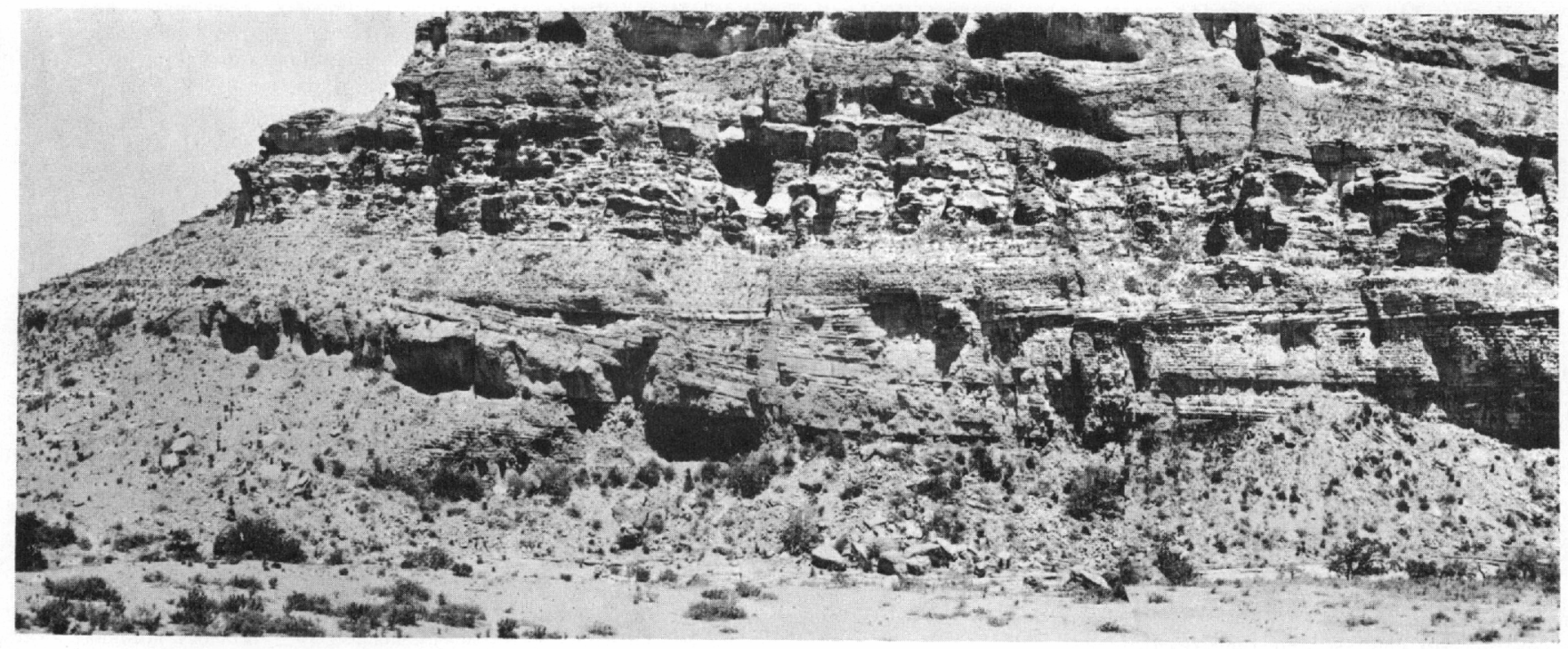

Fiavan 13.-Bedding features in the lower cherty member of the San Andres Limestone in Last Chance Canyon between the mouths of Wilson and White Oaks Canjons. 
sisting primarily of quartz silt, average from 10 to 15 percent in Last Chance Canyon and less than 5 percent to the northwest. The siltier carbonates tend to be yellowish gray rather than medium gray.

Thickness of the lower cherty member in Last Chance Canyon is unknown because the base is not exposed. A maximum of about 400 feet is exposed upstream from the mouth of Roberts Canyon. About 150 feet of beds at the top of the member in Roberts Canyon (stratigraphic section $7, \mathrm{pl} .3$ ) is apparently missing near the mouth of Sitting Bull Canyon owing to erosion beneath the unconformity at the top of the member (stratigraphic section 9, pl. 3; fig. 14). Because of the unconformity, the lower cherty member in Last Chance Canyon is probably thinner than it is to the northwest. The thickness of the lower cherty member is unknown in the nearby Humble Huapache 1 or the Union White 1 wells because of thick intervals in which samples were not recovered. In the first-named well, however, the member is apparently at least 470 feet thick.

In the Last Chance Canyon area the upper member of the San Andres Limestone is thin. Near the mouth of Roberts Canyon it is 78 feet thick and consists of wellbedded light-gray noncherty dolomite which contains abundant fusulinid molds in some beds (stratigraphic section $7, \mathrm{pl} .3$ ). The member is similar throughout the Last Chance Canyon area, and its thickness ranges from about 50 to 100 feet. Five samples of carbonate analyzed by the versenate method proved to be dolomite with calcite-dolomite ratios of $2: 98$ to $5: 95$.

Between the mouths of Roberts and Sitting Bull Canyons the upper member of the San Andres thickens, and most of it grades laterally into the sandstone tongue of the Cherry Canyon Formation. The thickening is due to the appearance of progressively younger rocks beneath the pre-Grayburg unconformity at the top of the formation (pl. 3; figs. 14, 15).

Most of the gradation between the upper member of the San Andres Limestone and the sandstone tongue of the Cherry Canyon Formation occurs between Wilson and Sitting Bull Canyons. A dolomite bed overlies, and interfingers with, the sandstone tongue of the
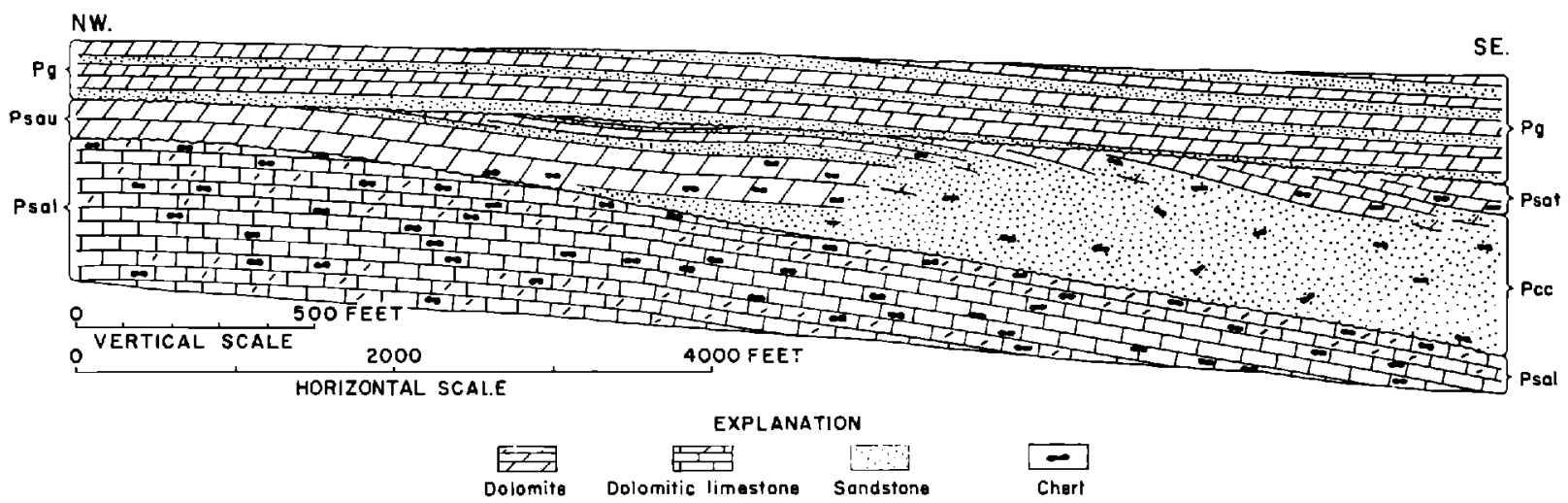

Figdae 14.--Diagram showing stratigraphic relations in Last Chance Canyon between the mouths of Roberts (northwest) and Sitting Bull (southeast) Canyons. Grayburg Formation, Pg; upper member of San Andres Limestone, Psau; tongue of San Andres, Psat; sandstone tongue of Cherry Canyon Formation, Pcc; lower cherty member of San Andres Limestone, Psal.

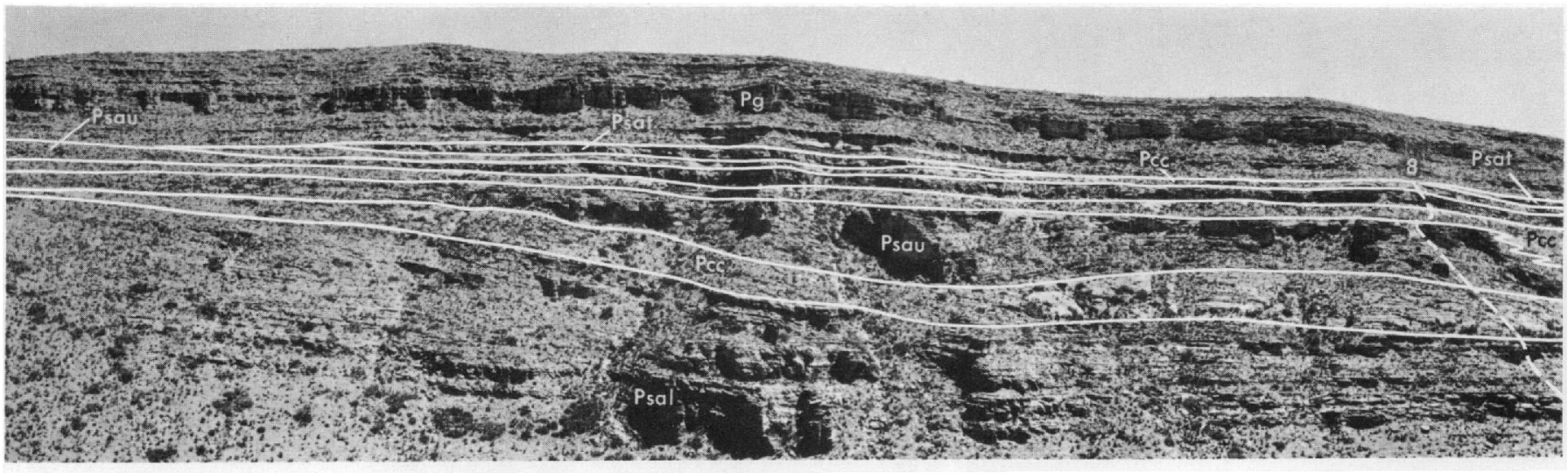

Figure 15.-North wall of Wilson Canyon near locality of stratigraphle section 8 . Thickening of the upper part of the lower eherty member of the San Andres Limestone (Psal) at left, thinning of the lowest tongue of the Cherry Canyon Formation (Pcc) at left, unusual swelling of a tongue of ulper member of the San Andres Limestone (Psau) in center, transition of the upper member of the San Andreg into the sandstone tongue of the Cherry Canyon Formation at right, and truncation of a tongue of the San Andres (Psat) and beds of the Cherry Canyon beneath evenly bedded Grayburg Formation ( $\mathrm{Pg}$ ). 
Cherry Canyon and extends eastward at least as far as the NW1/4 sec. 35 , T. 23 S., R. 22 E., where it plunges beneath the floor of Last Chance Canyon. The bed is probably a tongue of the San Andres, although it is truncated by the pre-Grayburg unconformity west of Sitting Bull Canyon and cannot be traced into the main body of the San Andres.

Near the mouth of Wilson Canyon, dolomite tongues of the San Andres Limestone extend eastward as far as half a mile into the Cherry Canyon Formation and then end abruptly by gradation into sandstone. These dolomite tongues are separated by sandstone tongues that pinch out westward into the San Andres. The eastward ends of the smaller tongues of dolomite and the basal few feet of the larger uppermost tongue of dolomite contain chert nodules similar to those in the sandstone tongue of the Cherry Canyon. The nodules diminish westward away from the sandstone tongue of the Cherry Canyon, and in Roberts Canyon no chert nodules occur in the upper member of the San Andres (stratigraphic sections 7 and 8, pl. 3; fig. 14).

The San Andres Limestone is overlain by the Grayburg Formation. Locally, the contact is an unconformity which is well displayed on the north walls of Last Chance and Wilson Canyons (figs. 14, 15) where more than 100 feet of uppermost beds of the San Andres are truncated in a distance of about a mile. The angular discordance here is about $1.5^{\circ}$. Unconformable relations between the two formations were not seen north or west of the Last Chance Canyon drainage in the Guadalupe Mountain area, but 20 miles to the southwest in the Brokeoff Mountains an unconformity is present above part of the transition zone between the upper member of the San Andres Limestone and the sandstone tongue of the Cherry Canyon Formation (Hayes, 1959, p. 2205-2206). This suggests that the unconformity is restricted to a narrow zone parallel to that facies boundary (fig. 9).

Where the contact between the San Andres and Grayburg is conformable, it is placed at the base of the lowest sandstone or siltstone bed in the Grayburg. Except near its transition into the sandstone tongue of the Cherry Canyon Formation, the San Andres is virtually free of clastic beds, whereas sandstone makes up onethird or more of the basal 75 feet of Grayburg.

The San Andres Limestone exposed in the area northwest of the Rocky Arroyo-Last Chance Canyon drainage divide is very sparsely fossiliferous, although fusulinid molds and dolomitized fusulinids are abundant in some layers, especially in the upper member. The transitional facies of the San Andres in Last Chance Canyon is, in general, more fossiliferous, and a few beds contain abundant silicified fossils. Newell and others (1953, p. 227-232) tabulated all fossil forms that had been previously described from the San Andres Limestone. Boyd ( 1958, p. 83-84) listed fossils from the northern exposures of the San Andres separately from those found in the transition facies and showed many forms which were previously undescribed from the San Andres. During the present investigation no additional forms were found in the upper member, but several previously unreported species of fusulinids were found in the lower cherty member in Last Chance Canyon. These fusulinids, which were identified by L. G. Henbest, of the Geological Survey (written communication, Apr. 11, 1958), have already been reported (Hayes, 1959, p. 2204) and include Parafusulina bosei var. attenuata (f-12396), Parafusulina sp. aff. P. sellardsi Dunbar and Skinner, 1937 (f-12398), and Parafusulina sp. cfr. "Schwagerina" setum Dunbar and Skinner, 1937 (f-12398).

Several geologists have collected fusulinids from the San Andres Limestone in Last Chance Canyon and Algerita Escarpment and have suggested age assignments for the rocks, but specific identifications have not been reported for most of the fusulinids. In summarizing age statements made by Skinner (1946, p. 1865), Wilde (1955, p. 59), Hollingsworth and Williams (in letter cited by Warren, 1955, p. 11), Clifton (1945, p. 1775), and Henbest (cited by Hayes, 1959, p. 2204), a latest Leonard and (or) earliest Guadalupe age was previously assigned to the lower cherty member in Last Chance Canyon (Hayes, 1959, p. 2202). Fusulinids collected by Clifton (1945, p. 1772-1773) and during the present investigation (Hayes, 1959, p. 2206) indicate a Guadalupe age for the upper member in Last Chance Canyon. This is to be expected in view of the laterally transitional relations of the upper member of the San Andres with the sandstone tongue of the Cherry Canyon Formation. Skinner (1946, p. 1865) collected several species of a fusulinid assemlage characterized by Parafusulina rothi from the lower cherty member on Algerita Escarpment (near stratigraphic section 1, pl. 3). This assemblage indicates equivalence to the Brushy Canyon or Cherry Canyon Formations. Skinner did not state from which part of the unit his fusulinids were collected, but they probably came from the upper 193 feet of the member which contains several fusulinid-bearing beds.

The distribution of exposures of the San Andres Limestone and equivalent rocks prevents direct field observation of the relations of the San Andres to rocks of the Delaware basin and the basin-margin area. Interpretation of those relations is summarized below following an enumerated review of the facts and assumptions which form the basis for the interpretations. 
1. As stated above, beds in the upper part of the San Andres Limestone grade laterally into the sandstone tongue of the Cherry Canyon Formation.

2. Boyd $(1955$, p. $49 ; 1958$, p. 14) demonstrated that beds in the lower part of the San Andres grade laterally into the Cutoff Shale.

3. The age and correlation of the Cutoff is somewhat controversial, but Newell and others (1953, fig. 7) consider it to be equivalent to the upper part of the Bone Spring Formation of the Delaware basin, and this correlation is tentatively accepted here.

4. P. B. King (1948, p. 20, 30) worked out relations in the Texas part of the Guadalupes that indicate that the contact between the Cutoff and the sandstone tongue of the Cherry Canyon Formation is an unconformity representing Brushy Canyon time.

5. As noted above, fusulinids collected by Skinner (1946, p. 1865) indicate a Guadalupe age for at least the upper 193 feet of the lower cherty member of the San Andres Limestone on Algerita Escarpment.

6. No unconformity is evident within or at the base of the lower cherty member in that area.

7. There is also no indication of an unconformity at the top of the San Andres in the northwestern part of the area, but in Last Chance Canyon the uppermost beds equivalent to the sandstone tongue of the Cherry Canyon Formation are missing beneath a local pre-Grayburg unconformity.

8. The basal beds of the Grayburg Formation are traceable from Last Chance Canyon to Algerita Escarpment and apparently are virtually synchronous across that interval.

9. The entire Grayburg Formation is apparently laterally transitional into the lower part of the Goat Seep Dolomite.

10. Total combined thickness of the Cutoff Shale and sandstone tongue of the Cherry Canyon Formation is less than 600 feet (King, P. B., 1948, pl. 6), whereas the San Andres Limestone is more than 1,200 feet thick.

Items 2,3 , and 5 listed above indicate that the lower 340 feet or less of the lower cherty member of the San Andres Limestone is laterally transitional southeastward into the Cutoff Shale of the basin-margin area. It is possible, however, that the lowermost beds of the San Andres are equivalent to the uppermost part of the Victorio Peak Limestone. Items 1, 7, 8, 9, and 10 above indicate that the upper part of the upper member of the San Andres of northwestern exposures is transitional into the sandstone tongue of the Cherry Canyon For- mation, except where removed by pre-Grayburg erosion. It is possible, but considered doubtful, that the uppermost beds of the San Andres were once transitional into the lowest beds of the Goat Seep Dolomite, as inferred by Newell and others (1953, fig. 6$)$.

The correlations stated above and item 6 indicate that rocks about $\mathbf{5 8 0}$ feet thick comprising the lower part of the upper member and the upper part of the lower cherty member of the San Andres Limestone in the northwestern part of the mapped area probably are equivalent to the Brushy Canyon Formation of the Delaware basin. This middle part of the San Andres, however, probably was never coextensive with the Brushy Canyon. P. B. King (1948, p. 30) has demonstrated that the Brushy Canyon Formation overlaps black limestone of the Bone Spring Limestone and the Cutoff Shale on the Bone Spring monocline. Thus, that flexure apparently forms the southeast flank of an arch, 15 to 20 miles wide, which was overlapped on the northwest by the middle part of the San Andres Limestone.

\section{ARTESIA GROUP}

'The Artesia Group was named by Tait and others (1962, p. 511) to include, in ascending order, the Grayburg, Queen, Seven Rivers, Yates, and Tansill Formations. As defined, the group includes a carbonate facies adjacent to the basin-margin facies and an evaporite facies farther shelfward. The Artesia Group thus replaces the abandoned Carlsbad Group which was defined to include the carbonate facies only of the Seven Rivers, Yates, and Tansill Formations (Hayes, 1957). Inasmuch as the constituent formations of the Artesia Group are distinguishable within the evaporite facies in the subsurface throughout southeastern New Mexico (Tait and others, 1962, p. 514-515), the Chalk Bluff Formation of Lang. (1937, p. 855-857) is also abandoned. The Chalk Bluff originally included all the rocks in the evaporite facies from the top of the San Andres Limestone to the base of the Salado Formation.

\section{GRATBURG FORNATION}

The rocks here included in the Grayburg Formation have been assigned in the past to many stratigraphic units. Exposures of the Grayburg in the northern part of the area were apparently included by Baker (1920, p. 117) in the base of the †Pecos Valley Red Beds of Beede (1910, p. 131). Darton and Reeside (1926, fig. $3-\mathrm{A})$, and later Crandall (1929, p. 933-935), included the Grayburg in the upper part of the fChupadera Formation. Lloyd (1929, p. 653) apparently included the Grayburg at the base of his Red sand group, whereas Blanchard and Davis (1929, pl. 10) mapped it as the upper part of the San Andres Limestone. Fiedler 
and Nye (1933, pl. 9-B) included the Grayburg in the base of their $\nmid$ Pecos Formation in the area just north of the present report area. The Dog Canyon Limestone of Lang (1937, p. 858-859) probably was approximately synonymous with the present-day Grayburg Formation and Goat Seep Dolomite. P. B. King (1948, p. 40), who abandoned the term Dog Canyon in favor of Goat Seep, used the latter term to include rocks located to the north that are now assigned to the Grayburg and Queen Formations. Skinner (1946, p. 18651867 ) included the Grayburg in the lower part of the Queen Formation.

The term Grayburg was proposed by Dickey (1940, p. 44 45) who designated the Cecil H. Lockhart Root. Permit 2 in sec. 7, T. 17 S., R. 30 E., Eddy County, N. Mex., as the subsurface type locality and suggested that at some future time the unit should be measured and defined on the outcrop in the Guadalupe Mountains. The earliest known use of the term for rocks cropping out in the Guadalupe Mountains is in a mimeographed guidebook (Stipp, 1951). Newell and others (1953, p. 43) used the term Grayburg Formation provisionally in the Guadalupe Mountains. Moran (1954) proposed locations for surface type sections of the Grayburg and Queen Formations in the Guadalupes, but he did not present either written or graphic sections. However, the use of the term Grayburg in this report and earlier reports (Hayes and Koogle, 1958; Hayes, 1959, p. 22072209) probably conforms closely to that intended by Moran. Boyd (1958, p. 28) mapped the unit with the Queen Formation referring to the combination as the "Grayburg-Queen sequence" in the El Paso Gap quadrangle because of the difficulty of distinction between the two formations in the many fault blocks of that quadrangle.

The Grayburg Formation crops out in a band several miles wide, extending from Martine Ridge northeastward across the mapped area. There are also inliers to the southeast and outliers to the northwest.

The Grayburg Formation overlies the San Andres Limestone and underlies the Queen Formation. It grades laterally southeastward into the lower part of the Goat Seep Dolomite.

Like most of the formations of the shelf facies, the Grayburg changes in character from southeast to northwest, but the following general description applies to most exposures in the report area. About four-fifths of the formation is very pale orange (weathering to grayish-orange) compact very finely textured dolomite and calcareous dolomite that generally occurs in beds 1 inch to 1 foot thick, although some beds are as thick as 10 feet. The rest of the formation consists of similarly colored very fine grained calcareous or dolomitic quartz sandstone mostly in beds 1 to 6 inches thick and in a few beds as thick as 5 feet. The proportion of sandstone to dolomite is somewhat greater in the lower part of the formation where some sandstone beds are locally very resistant (stratigraphic sections 9 and 10, pl. 3; fig. 15). Calcite-dolomite ratios of carbonate rock from the Grayburg computed from 8 spectrographic analyses (Boyd, 1958, p. 31) and from 5 versenate analyses made for this report range from $17: 83$ to $0: 100$ and average $4: 96$. Of the samples analyzed, 11 are classed as dolomite and 2 as calcareous dolomite.

The Grayburg in Gilson and Trimble Canyons is about 435 feet thick (stratigraphic sections 10 and 11, pl. 3), and it is 425 feet thick on the Shattuck Valley scarp (stratigraphic sections 18 and 19, pl. 3). A section of the Grayburg reported by Moran (1954) as 475 feet thick in Sitting Bull and Gilson Canyons may include 50 feet of dolomite at the base that is here mapped as a tongue of the San Andres Limestone (pl. 1). The Grayburg thickens southeastward and may be as thick as 600 feet near its transition into the Goat Seep Dolomite. Conversely, it probably thins to 400 feet or less near the north edge of the area. In the subsurface of northeastern Eddy and Lea Counties the Grayburg ranges in thickness from about 200 to 450 feet and averages about 325 feet (Bates, 1942b).

The contact between the Grayburg Formation and the underlying San Andres Limestone appears parallel and conformable throughout the area, except for the local low-angle unconformity in the Last Chance Canyon area described on page 27. Everywhere the contact is marked by a rather sharp change in lithology. Almost sandstone-free yellowish-gray to light olivegray-weathering dolomite in the upper part of the San Andres contrasts with the alternating beds of grayishorange-weathering sandstone and dolomite in the lower part of the Grayburg (pl. 3). In the El Paso Gap quadrangle the basal contact of the Grayburg Formation as designated by Boyd $(1958$, p. 22$)$ is about 300 feet lower than the contact used in this report. The contact used here is preferred because it is more easily mapped, and because it agrees more closely with Dickey's (1940, p. 44-47) original definition. Reasons for placing the contact as used in this report have previously been reported in detail (Hayes, 1959, p. 22102211).

The contact between the Grayburg Formation and overlying Queen Formation is arbitrarily placed at the base of a locally conspicuous sandstone sequence assigned to the Queen.

The lateral transition of the Grayburg Formation into the Goat Seep Dolomite is partly exposed in the report area in the upper end of North McKittrick Can- 
yon (pls. 1,3). The complete transition can be seen below Blue Ridge on the west side of the Guadalupe Mountains in Texas, 5 miles south of the present mapped area (Newell and others, 1953, p. 45). Graphic sections illustrating the transition at that locality are shown by P. B. King (1948, stratigraphic sections 5 and 6 , pl. 6). Near the transition into the Goat Seep Dolomite, dolomite of the Grayburg changes from very pale orange to light gray, and becomes coarser and thick bedded; the sandstones become increasingly dolomitic and grade into slightly sandy dolomite. Fusulinid molds and oolitic layers are common in the dolomite beds of the Grayburg in the transition zone (fig. 16). Most of the Grayburg Formation exposed in Dark and Trimble Canyons is in the transition zone.

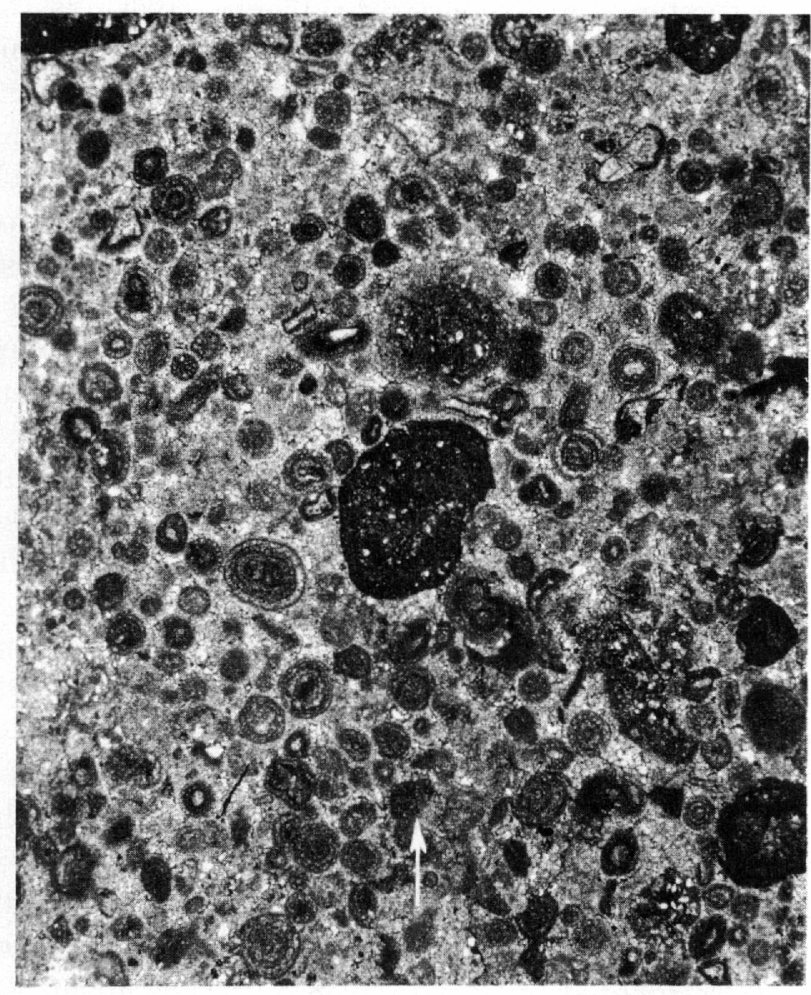

Figure 16.-Photomicrograph of dolomite from near the top of the Grayburg Formation at stratigraphic section 20. This oolitic dolomite is typleal of the Grayburg and Queen Formations near their transition into the Goat Seep Dolomite. Oolites are in a finely crystalline dolomite matrix. Isarge dark area in center is a rounded clast of sandy dolomite possibly derived from the Goat Seep. 1 mm-long arrow points up.

Near the north edge of the mapped area, dolomite of the Grayburg is very thin bedded, aphanitic gypsum beds are present, and sandstone beds are less resistant and pinker than in areas farther to the south. In the vicinity of Box Canyon the basal 50 feet of the formation is about 30 percent friable yellowish-gray sandstone, 30 percent friable pale-red sandstone and siltstone, 30 percent thin-bedded aphanitic dolomite, and
10 percent gypsum. Within a distance of 5 miles north of the mapped area, virtually all the sandstone is replaced by red beds and much of the dolomite by gypsum.

Although the term Grayburg was applied to rocks in the Guadalupe Mountains as early as 1951 (Stipp, 1951 ; 1952 , p. $8-10$; Newell and others, 1953 , p. 43 ; Moran, 1954; Boyd, 1958, p. 28), there was doubt as to the actual equivalence of the rocks so identified with the original subsurface Grayburg Formation. In an earlier paper (Hayes, 1959, p. 2208), evidence was presented to show that the surface and subsurface Grayburg are virtually the same. The Grayburg Formation can easily be correlated in a series of wells from its subsurface type in Lockhart Root Permit 2 well in eastern Eddy County to Magnolia State "W" 1; the latter well was located on outcrops of the Grayburg in the report area (fig. 17).

\section{QUEEN FORMATION}

The Queen Formation was originally named the Queen Sand by Crandall (1929, p. 940) for exposures in the vicinity of the old Queen Post Office, sec. 30, T. 24 S., R. 22 E., but a type section was not designated. Only the lower part of the formation is exposed near the ruins of Queen, but the upper part of the unit was identified by Crandall $(1929$, p. 940) in Rocky Arroyo, T. 21 S., R. 24 E. The Queen was subsequently recognized in many oil fields in the shelf areas of southeast New Mexico (Bates, 1942b). The upper and lower limits of the formation on the surface were formally defined by Newell and others (1953, p. 44 45). Moran (1954) established a type locality for the formation on the west wall of Dark Canyon in SW1/4 sec. 36, T. 24 S., R. 22 E.

In the mapped area the Queen Formation is exposed in an irregularly shaped northeastward-trending outcrop band extending from Shattuck Valley to the northwest side of the Hess Hills. It is also exposed in Fawn Valley, Johnson and Trail Canyons, and in many small outliers on the Grayburg Formation.

The Queen Formation is lithologically similar to the Grayburg Formation; the two units differ primarily in the proportion of contained rock types. An average of about one-fifth, and at no place more than onefourth, of the Grayburg consists of clastic rocks; an average of two-fifths, and at no place less than onethird, of the Queen is made up of clastic rocks.

Carbonate rock of the Queen and Grayburg are similar. In general, it is very pale orange compact very finely textured dolomite and calcareous dolomite that weathers pale yellowish brown. Individual beds are generally less than 1 foot thick, though some beds are as much as 5 feet thick. Calcite-dolomite ratios com- 


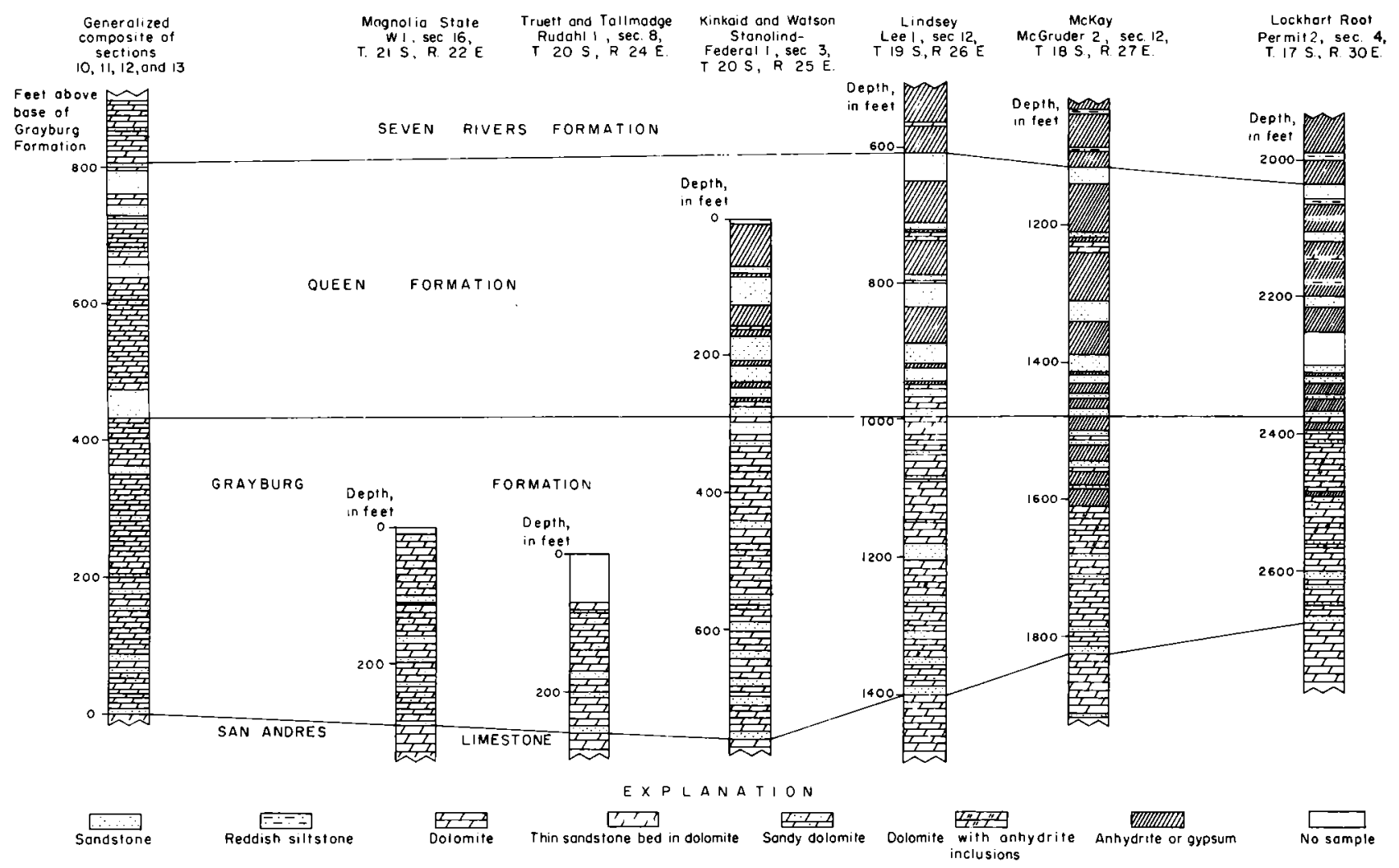

FIGURE 17. - Surface and well sections showing correlation of the Grayburg and Queen Formations from outcrop area in Guadalupe Mountains to original subsurface type section of the Grayburg Formation in Lockhart Root Permit 2 well (Dickey, 1940). Well sections were interpreted from sample descriptions. Numbers to left of well sections indicate depth in feet below surface; numbers to left of composite surface section indicate stratigraphic interval above base of the Grayburg Formation.

puted from spectrographic analyses of 4 samples (Boyd, 1958, p. 31) and from versenate analyses of 9 samples made during the present work range from $48: 52$ to $0: 100$, and average $10: 90$. Of the samples analyzed, 9 are classified as dolomite and 4 as calcareous dolomite.

Clastic rocks in the Queen are largely confined to the upper 100 feet and the lower 50 feet of the formation. The clastic rocks consist of very pale orange very fine grained sandstone and siltstone that weathers pale yellowish brown and is cemented with carbonate. Sandstone is predominant in the lower part of the formation, and siltstone is predominant in the upper part. In general, the sandstone occurs in beds more than a foot thick, whereas the siltstone is generally in thin platy beds. The largely silty sequence in the top 100 feet of the Queen Formation was named the Shattuck Member by Newell and others (1953, p. 45) for outcrops along the Shattuck Valley escarpment in the vicinity of Devils Den. The member was not mapped separately during the present investigation.

The thickness of the Queen Formation ranges from about 210 feet below Deer Hill on the Shattuck Valley escarpment (stratigraphic section 19, pl. 3) to a re- ported 421 feet at Moran's (1954) type section in Dark Canyon. It is 378 feet thick at the site of an abandoned CCC camp farther down Dark Canyon (stratigraphic section 12, pl. 3, and p. 59-60). Bates (1942b) reports subsurface thicknesses of the Queen ranging from 305 to 475 feet and averaging about 400 feet in oil fields in northeastern Eddy and Lea Counties.

The contact between the Queen Formation and underlying Grayburg Formation is conformable and is arbitrarily placed at the base of a locally conspicuous sandstone bed (stratigraphic sections 11, 12, 19, 20, pl. 3 ). This basal sandstone varies in thickness and is difficult to trace at some places. It is particularly difficult to identify in isolated outcrops and where exposures are poor. Boyd (1958, pl. 1) mapped the Queen and Grayburg as a single unit which he called the "Grayburg-Queen" sequence. Skinner (1946, p. 1865-67) included both the Queen and Grayburg of this report in his Queen Formation, but recognized the probable equivalence of the lower part to the Grayburg of the subsurface.

The contact between the Queen Formation and overlying Seven Rivers Formation is sharp, but it is parallel and apparently conformable. The siltstone of the Shat- 
tuck Member at the top of the Queen is easily distinguished from the dolomite or gypsum beds at the base of the Seven Rivers.

Most of the Queen Formation grades laterally southeastward into the upper part of the Goat Seep Dolomite, but the upper part of the Shattuck Member may pinch out between the Goat Seep and overlying Capitan Limestone (fig. 9). Rocks transitional from the Queen to Goat Seep are exposed in the walls of North McKittrick Canyon (stratigraphic sections 20 and 21, pl. 3). The transitional beds are very similar to the alreadydescribed underlying rocks that are transitional from the Grayburg to Goat Seep. As is true in most of the other facies changes in the report area, the Grayburg and Queen grade into the Goat Seep farther to the southeast in the younger beds, so that the Queen Formation locally overlies part of the Goat Seep (pls. 1,3).

The lithology of the Queen Formation changes toward the northwest, although this cannot be seen in the mapped area because so little of the Queen is preserved in outcrops. Within the Seven Rivers Embayment (fig. 1), however, the dolomite of the Queen is largely replaced by gypsum, and the clastic beds of the formation change from very pale orange to pale reddish brown. These changes occur in the subsurface and are illustrated in figure 17.

The Queen of subsurface usage, as identified by Dickey $(1940$, p. 45$)$ in the Lockhart Root permit 2 well in northeastern Eddy County (stratigraphic section 7, T. $17 \mathrm{~S}$., R. $30 \mathrm{E}$.) can be correlated in a series of wells from the Lockhart well to the Kinkaid and Watson Stanolind-Federal 1 (sec. 3, T. 20 S., R. 25 E.) (fig. 17) ; the latter was drilled on the outcrop of the Queen Formation (Dane and Bachman, 1958). The Shattuck Member at the top of the Queen is probably the "Artesia red sand" of subsurface usage (Bates, 1942b).

\section{SEVEN RIVERS FORMATION}

The term Seven Rivers was first applied by Meinzer, Renick, and Bryan (1926, p. 13-14) to the Seven Rivers Gypsiferous Member of the now-abandoned Chupadera Formation for exposures south of Seven Rivers, at the north end of the Seven Rivers Hills (fig. 1). Lang (1937, p. 860) included the Seven Rivers Gypsiferous Member in his Chalk Bluff Formation, but he recognized the contemporaneity of the Seven Rivers and the lower part of his Carlsbad Formation. As the result of a symposium (DeFord and Lloyd, 1940, p. 8-11), the Seven Rivers was raised to formational status and expanded laterally to include equivalent bedded carbonates.

The Seven Rivers Formation conformably overlies the Queen Formation, conformably underlies the Yates
Formation, and grades laterally souteastward into the lower part of the Capitan Limestone. It is exposed in continuous outcrop from North McKittrick Canyon to the East Hess Hills and in many inliers and outliers.

The bedded carbonate facies of the Seven Rivers between its southeastward transition into the Capitan Limestone and its northwestward transition into the evaporite facies is 5 to 7 miles wide. Lateral changes in lithology and bedding within the carbonate facies are considerable, but, in general, the unit consists dominantly of yellowish-gray dolomite which weathers light olive gray. Also present, but constituting less than 10 percent of the formation, are a few beds of very pale orange quartzose siltstone cemented with dolomite. Calcite-dolomite ratios of the carbonate rock were computed from versenate analyses of 8 samples collected during the present work, from chemical analyses of 2 samples reported by P. B. King (1948, p. 66), and from 1 spectrographic analysis reported by Newell and others $(1953$, p. 61$)$. These ratios range from $32: 68$ to $0: 100$ and average $6: 94$. Nine of the samples are classed as dolomite, and two, both collected from near the transition into the Capitan Limestone, are classed as calcareous dolomite.

Individual beds of dolomite in the Seven Rivers range in thickness from 5 to 10 feet or more near the Capitan Limestone and are generally less than 1 foot thick near the transition into the evaporite facies. The texture of the dolomite also changes markedly. Adjacent to the Capitan Limestone, fusulinid coquinas are common (fig. 18) and dolomitized mollusks occur. Farther

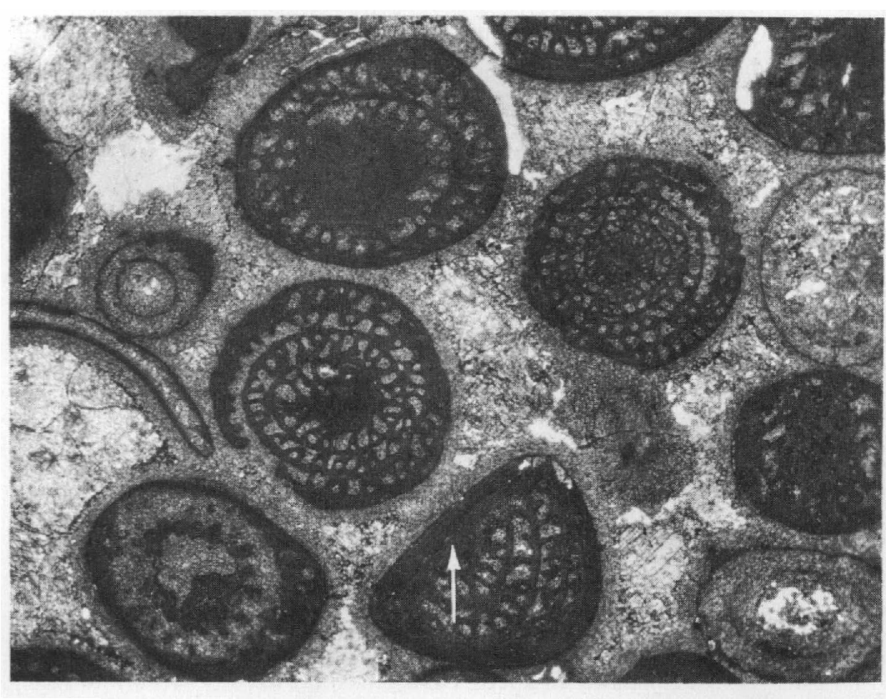

Frgdre 18.-Photomicrograph of fusulinid coquina from the Seven Rlvers Formation near its transition into the Capitan Limestone. Fusulinids (probably Polydiexodina) are all oriented in same direction with long axes subparallel to trend of facles change. Smaller circular bodies randomly mixed with the fusulinids are the algae Mizzia. Matrix is very finely crystalline dolomite partially replaced by sparry calcite. $1 \mathrm{~mm}$-long arrow points up. 
northwestward, from a few hundred feet to 2 miles from the Capitan, pisolites generally less than 1 inch in diameter are extremely abundant and locally make up much of the formation (stratigraphic section 14, pl. 3). The pisolites become smaller to the northwest, and the pisolitic facies is bounded on the northwest by a narrow oolitic facies (fig. 19). Still farther northwestward, the dolomite of the Seven Rivers is increasingly fine grained, and near its transition zone to the evaporite facies it is aphanitic.

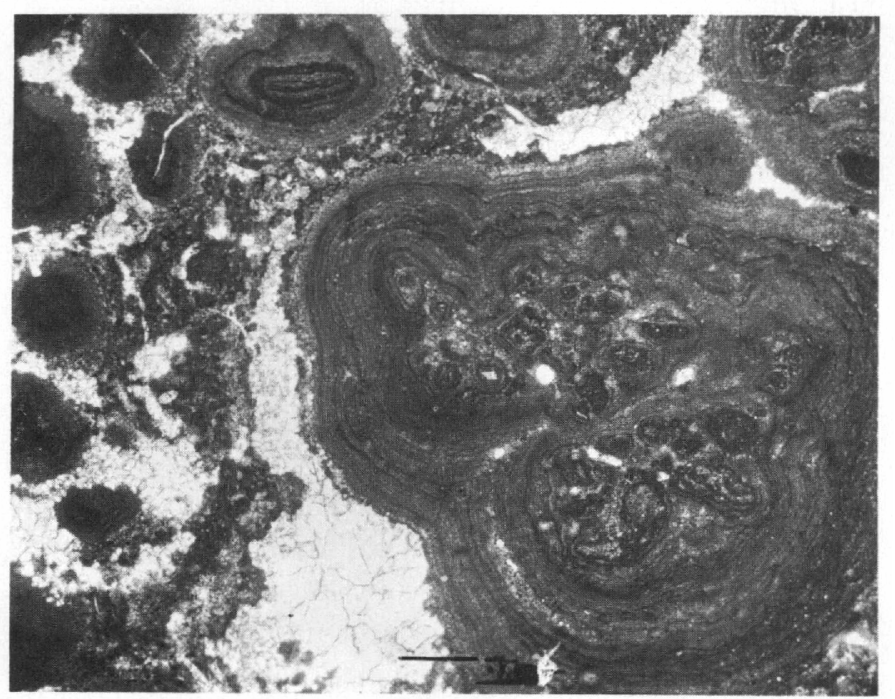

Figdaf 19.-Photomicrograph of pisolitic carbonate from the lower part of the Seven Rivers Formation at stratigraphic section 21. Large pisolite has a nucleus of three smaller pisolites which, in turn, have nuclene of several oolites and minute rock fragments. White areas are crystalline calcite which has apparently replaced the outer edges of the pisolites and some of the dolomite matrix. Bar is 1 min long.

Unusual sedimentary features, called tepee structures by Adams and Frenzel (1950, p. 305), are common in dolomite of the Seven Rivers within 2 miles of the Capitan Limestone. These structures, which are more conspicuous in the overlying Yates Formation, are described on pages $34-35$.

The transition of individual beds of the Seven Rivers into the Capitan takes place within a few hundred feet but, from the base to the top of the Seven Rivers, the transitional zone shifts southeastward more than 1 mile (pls. 1,3). In approaching the Capitan, carbonate beds of the Seven Rivers first thicken conspicuously and then the bedding planes disappear in the virtually unbedded Capitan Limestone. The dolomite of the Seven Rivers simultaneously changes rather abruptly into the almost pure limestone of the Capitan. The changes in bedding and mineralogy are accompanied by changes in texture from bioclastic and pisolitic in the Seven Rivers to biogenic in the Capitan. Accompanying the change in the carbonate rocks, the thin siltstone beds of the Seven
Rivers become increasingly dolomitic and then either abruptly grade into limestone or pinch out.

The lateral gradation within the Seven Rivers formation from the carbonate to the evaporite facies takes place near the northwest limit of exposures of the Seven Rivers Formation in the mapped area. The geologic map (pl. 1; see also fig. 9) shows the approximate position of the facies change on the southeast side of the Hess Hills. The change also occurs near El Paso Gap where an outlier of Seven Rivers in Shattuck Valley is evaporite rock, whereas a short distance to the south on El Paso Ridge, the Seven Rivers consists mostly of carbonate rocks. Boyd (1958, p. 16-17 and pl. 1) mapped these rocks near El Paso Gap as a part of the Grayburg Formation.

The change from the carbonate facies to the evaporite facies takes place within a few hundred feet laterally. Rocks in the transition zone are not well exposed in the mapped area, but they can be seen on the north side of Last Chance Canyon above the mouth of Johnson Canyon, about 2 miles north of the mapped area. The transitional rocks are well exposed also in Rocky Arroyo at the south edge of the Seven Rivers Hills (fig. 1). Bates (1942a) described the facies change at that locality, where it is accomplished by interfingering of thin beds of dolomite and gypsum as well as by abrupt southeastward lithologic change from gypsum to carbonate rock. Some thin beds of sublithographic dolomite extend far into the evaporite facies. A tongue of dolomite that extends northwestward over the gypsiferous lower part of the formation was named the Azotea Tongue by Lang $(1937$, p. 868$)$ for exposures on the west edge of Azoter Mesa (fig. 1). The siltstone beds of the Seven Rivers change from very pale orange in the main body of the carbonate facies to pale reddish brown near the zone transitional with the evaporite facies. Although it is not evident within the mapped area, the gradation takes place progressively farther northwestward from bottom to top of the Seven Rivers. In the subsurface, beneath the zone of surface hydration, sulfate rock of the evaporite facies is anhydrite rather than gypsum.

The Seven Rivers Formation is about 460 feet thick at Bear Canyon (stratigraphic section 13, pl. 3 ; p. 60 61 ), about $1 \frac{1}{2}$ miles northwest of the Capitan Limestone, and is probably about the same thickness elsewhere at the same distance from the Capitan. The formation thickens near the Capitan to a possible 600 feet.

\section{YATES FORMATION}

The Yates Sandstone was named by Gester and Hawley $(1929$, p. $487-488)$ as a subsurface unit in the Yates oil field, Pecos County, Tex. It was subsequently recognized as "the most persistent lithologically of all 
formation of Whitehorse age in the West Texas-New Mexico Permian basin" (Fritz and FitzGerald, 1940, p. 25) and "is one of the best known and most reliable widespread stratigraphic key horizons in the Permian basin" (Woods, 1940, p. 34). Woods (1940, fig. 1) and Dickey (1940, fig. 1) correlated the top of the Yates from Pecos County, Tex., into Lea and Eddy Counties, N. Mex. DeFord, Riggs, and Wills (1938) traced the Yates from the subsurface to outcrops near Carlsbad, and DeFord and Riggs (1941, fig. 3) published a line of stratigraphic sections showing correlation of the Yates and overlying Tansill Formation between the subsurface in Lea County and a surface section measured less than 2 miles from the present mapped area in and near the SW1/4 sec. 27, T. 23 S., R. 25 E. The Yates Formation of the surface, as established by DeFord and Riggs, is used in this report. The Three Twins Member of the Chalk Bluff Formation (Lang, 1937 , p. $862-863$ ) is virtually the same as the evaporite facies of the Yates and Tansill Formations combined. The name Three Twins is therefore abandoned.

In the mapped area, the Yates Formation crops out in many outliers and inliers on and near northeastwardtrending Guadalupe Ridge. It is most extensively preserved in the northern part of the area.

The Yates is underlain by the Seven Rivers Formation and overlain by the Tansill Formation with conformable but sharp contacts (figs. 20, 26). As stated above, the Yates grades southeastward into the Capitan Limestone. The Yates is characterized by very persistent siltstone and sandstone beds which make up $1 / 3$ to $2 / 3$ of the formation; the adjacent Seven Rivers and Tansill Formations are predominantly dolomite.

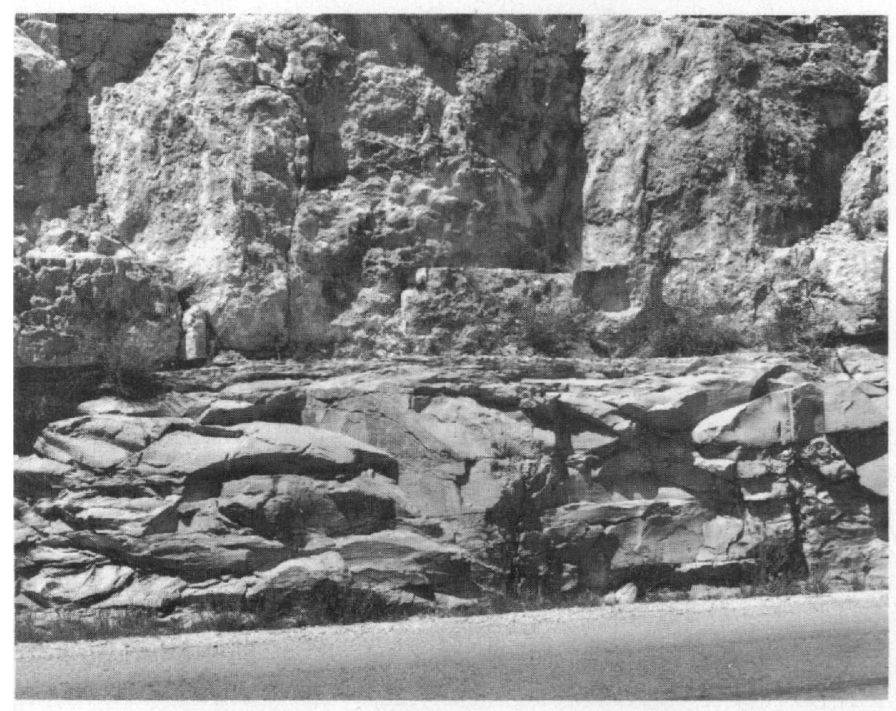

Figdre 20.-Contact between siltstone at the top of the Yates Formation and dolomite at the base of the Tansill Formation along Carlabad Caverns National Park road in $\mathrm{S} 1 / 2$ sec. 30, T. $24 \mathrm{~S}$., R. $25 \mathrm{E}$.
As in the Seven Rivers Formation, lithology of the Yates is variable laterally in a southeast-northwest direction. Dolomite of the Yates is similar to that of the Seven Rivers. Near the transition into the Capitan the dolomite is very thick bedded and bioclastic and contains abundant fusulinids. Farther to the northwest the rock is thick bedded and pisolitic. Beyond the pisolitic facies is a narrow band in which the rock is oolitic. Still farther northwest the dolomite is more thinly bedded, and it becomes aphanitic as one approaches the zone in which dolomite is transitional into evaporites. Versenate analyses for calcium and magnesium were made of three samples of carbonate rock from the Yates. Computed calcite-dolomite ratios range from $12: 88$ to $0: 100$ and average $6: 94$. One sample is classified as calcareous dolomite and two as dolomite.

Many small primary structures resembling anticlines, called tepee structures by Adams and Frenzel (1950, p. 308), are present in the dolomite beds of the Yates within about 11/2 miles of the Capitan Limestone. Similar structures also occur in the Seven Rivers and Tansill Formations, but they are much more common in the Yates. Those in the Yates are particularly conspicuous in Walnut Canyon. They are confined to layers 3 to 30 feet thick which are overlain and underlain by undisturbed beds. The structures are seldom exposed except in cross section, but they are apparently linear and are always anticlinal. As noted by Newell and others (1953, p. 127-128), no systematic trend of the structures is apparent. The individual beds involved in the structures are commonly broken and crumpled along the axial planes, which commonly contain recrystallized dolomite. Most of the folds are confined to dolomite, but, in some, very thin beds of siltstone are involved. Most of the structures flatten abruptly upward, owing to thinning of dolomite beds over the crests; in a few, the crests of the folds are truncated. All are obviously primary structures.

Adams and Frenzel (1950, p. 307-308) attributed the folds to compression contemporaneous with deposition, but they said that the cause of the compression was not apparent. Newell and others (1953, p. 126-127), however, noted that the folds do not display such compressional features as overturned axial planes and shear surfaces. They postulated that gypsum may have "squeezed upward along joints, penetrating between the layers close to the joint and working its way upward until all the gypsum from what must have been a thin layer was exhausted," or that the structures "may have formed during the Permian period by expansion of crystallizing salts, perhaps the inversion of anhydrite to gypsum, along joints and bedding planes." A com- 
bination of the two processes postulated by Newell and others (1953, p. 126-127) would also seem reasonable, that is, that anhydrite was squeezed upward along joints and later inverted to gypsum, except that there is little evidence that sufficient anhydrite or gypsum was deposited so close to the Capitan Limestone during Yates time. Boyd (1958, p. 50-51) observed similar tepee structures in the "Grayburg-Queen sequence" and suggested that "Intrastratal flowage of material in unconsolidated beds due to differential loading merits equal consideration as a cause." It is here suggested that intrastratal flowage of unconsolidated sediment might have taken place down the slight depositional slope away from the Capitan Limestone. This would, of course, have induced minor compression and probably could have produced the tepee structures.

The quartzose siltstone and sandstone units in the Yates Formation are less resistant to erosion than is dolomite, and they generally weather to slopes between cliffs and ledges of dolomite. They are generally laminated and oceur in beds which range in thickness from less than 1 inch to several feet. The color of the weathered rock is mostly very pale orange and grayish orange near the Capitan Limestone and is reddish orange and reddish brown farther northwest.

Detrital grains in the siltstone and sandstone are mostly quartz, but scattered feldspar grains are generally present (fig. 21). The average grain size is very close to the division between silt and very fine sand. Sandy siltstone probably is more abundant than silty sandstone, however. Size sorting is generally very good. Cementing material in the siltstone and sandstone is generally dolomite, but in some beds it is calcite cement.

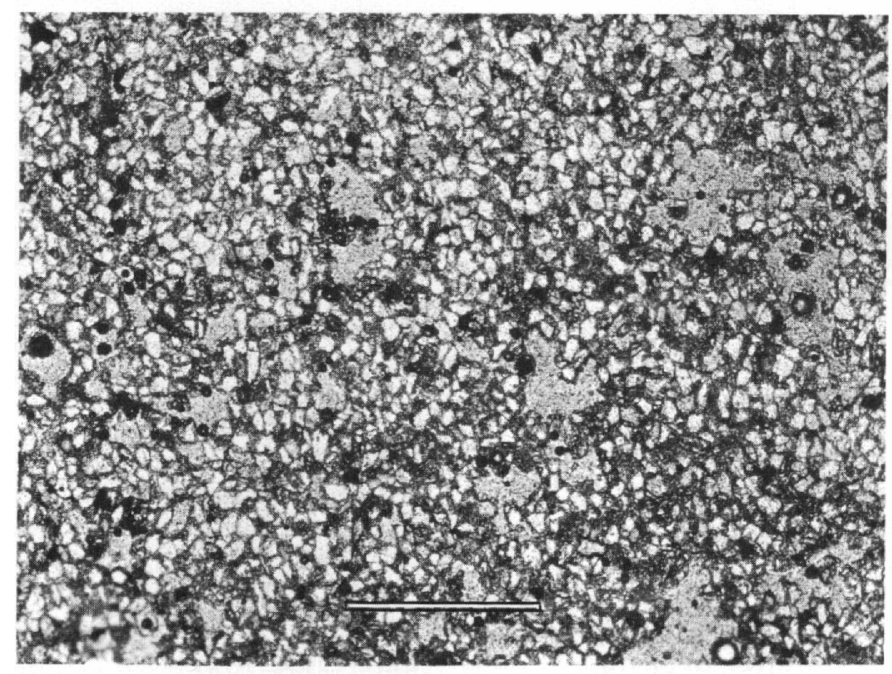

Figure 21.-Photomicrograph of well-sorted coarse slltstone from the Yates Formation. Cementing material is dolomite which has apnarently replaced outer margins of quartz grnins. Larger irregular light-gray areas are dolomite. Small opaque spherules may be I1monite or pyrite. Bar is $1 \mathrm{~mm}$ long.
Argillaceous material makes up a very small fraction of all the clastic rocks and seems to increase toward the northwest. Within 2 miles of the Capitan, the siltstone and sandstone beds locally contain numerous nodules, as much as several inches in diameter, of limonite or goethite pseudomorphous after pyrite.

Lateral transition of the Yates Formation into the Capitan Limestone takes place farther to the southeast than transition of the Seven Rivers into the Capitan, and the upper part of the Yates makes the transition farther to the southeast than does the lower part (pls. 1, 3 ; fig. 9). Rocks in the transitional zone are particularly well displayed on the north wall of Slaughter Canyon (fig. 10). Near the Capitan, dolomite beds of the Yates thicken conspicuously and become calcitic. At the vaguely defined boundary between the Yates and the Capitan, bedding planes disappear and the carbonate becomes limestone. At approximately the same place, sandstone and siltstone of the Yates grade rather abruptly into limestone (stratigraphic sections 2 to 6 , pl. 3). Several hundred feet southeast of the YatesCapitan boundary the stratigraphic horizon of the highest siltstone of the Yates is represented by a notch in the Capitan Limestone cliffs (stratigraphic sections 6 and 17, pl. 3). Newell and others (1953, p. 131-140) discussed in detail facies changes within dolomite of the Yates.

Transition of the dolomite facies of the Yates into the evaporite facies is not complete in the report area; however, the transition can be seen in poor exposures to the northeast near Carlsbad, and it is well known in the subsurface east of Carlsbad. In exposures of the Yates northwest of Crooked Creek the dolomite is very thin bedded and aphanitic, the siltstone is pale red, and the formation contains some gypsum. This lithology indicates that even though it is now removed by erosion, the evaporite facies was once present a short distance northwest of the present exposures.

The Yates Formation is 328 feet thick ${ }^{3}$ where measured in North Rattlesnake Canyon (stratigraphic section 2 , pl. 3 ; p. 59). Toward its transition into the Capitan Limestone in North Slaughter Canyon the formation thickens to at least 375 feet, owing to a thickening of the dolomite beds (stratigraphic section 16, pl. 3). In two sections measured in Dark Canyon in T. $23 \mathrm{~S}$., R. $25 \mathrm{E}$, a few miles outside the report area, the Yates is 262 and 287 feet thick.

\section{TANBILL FORMATION}

The Tansill Formation is the youngest formation in the Artesia Group. Exposures about 4 miles northwest

\footnotetext{
${ }^{3}$ A previously reported thickness of 270 feet for the Yates in North Slaughter Canyon (Hayes and Koogle, 1958) is erroneous.
} 
of Carlsbad, near the reservoir behind Tansill power dam, were first formally described as the Tansill by DeFord and Riggs (1941).

The Tansill Formation is extensively exposed northeast of Walnut Canyon; to the southwest it forms outliers capping the Reef Escarpment. The Tansill conformably overlies the Yates Formation and Yates equivalents in the massive member of the Capitan Limestone. The Tansill grades southeastward into the uppermost part of the Capitan Limestone. No younger beds of Permian age overlie the Tansill Formation within the mapped area, but the Tansill is overlain by the Salado Formation in the subsurface east of the Pecos River (fig. 2). The upper contact has been discussed on page 16.

Within the report area, the Tansill Formation is composed mainly of dolomite which is nearly identical to the dolomite in the Seven Rivers and Yates Formations. It also contains thin beds of siltstone similar to siltstone in the two underlying formations. A siltstone unit 8 feet thick, called the Ocotillo Silt Member by DeFord and Riggs (1941, p. 1717), occurs about 100 feet above the base of the Tansill. This siltstone was not mapped, but it is traceable over much of the northern part of the Tansill outcrop area.

The transition of the Tansill into the Capitan Limestone takes place southeast of the Yates and Capitan transition, and the upper part of the Tansill grades into the Capitan southerst of the transition of the lower part of the Tansill into the Capitan. The facies change is virtually identical to the Seven Rivers and Capitan transition. In the subsurface northeast of Carlsbad, the Tansill grades laterally shelfward from carbonates to evaporites within a few miles of the Capitan, but in the report area rocks showing the carbonate-evaporite facies change were removed by erosion. Presumably, it is much like the carbonate-evaporite transition of the Seven Rivers described on page 33.

It is impossible to measure a complete thickness of the Tansill in the report area because its top is not preserved. DeFord and Riggs (1941, p. 1723) believed that about 5 feet of rock was missing from the top of the Tansill at the type locality, where they measured a thickness of 123.5 feet for the formation. They reported (p. 1722) that the Tansill thickens to more than 300 feet southeastward near the Capitan Limestone. An incomplete section about 325 feet thick is preserved in Rattlesnake Canyon (stratigraphic section 5, pl. 3) very near the Capitan. In the subsurface in Eddy and Lea Counties, the Tansill ranges between about 90 to 200 feet in thickness (Bates, 1942b).
FOSSILS OF THE ARTE8IA GROUP

In the northern part of the area, the Grayburg and Queen Formations seem to be almost completely devoid of fossils, but toward the south dolomitized and silicified fossils and fusulinid molds occur sporadically. Boyd (1958, p. 67-71) reported on several collections from the "Grayburg-Queen sequence," but some were apparently from beds here included in the upper part of the San Andres Limestone. Concerning one definite Grayburg fossil locality in $\mathrm{SW}_{1 / 4} \mathrm{SW}_{1 / 4}$ sec. $9, \mathrm{~T}$. 25 S., R. 21 E., Boyd (p. 70) states

"Composita and Hustedia were found associated with numerous gastropods, including one bellerophontid species, 2 subulitid species, and one naticopsid species, which were represented by more individuals than were all the other species combined."

His largest collection, from near Hamm Draw in sec. 2 , T. 25 S., R. 21 E., is believed to have been from the uppermost part of the Grayburg Formation, although it was reported to be from the Queen. The collection contained representatives of at least 26 species of mollusks, 1 coral, 1 ostracode, and bryozoan fragments (Boyd, 1958, p. 85-86). The gastropod Bellerophon majusculus was most abundant. Newell and others (1953, p. 143) collected specimens from the Grayburg at six localities and reported Parafusulina, crinoids, brachiopods, pelecypods, gastropods, nautiloids, and algae; but their faunal list (p. 227-232) does not identify species. Locality 7628 reported by Girty (in P. B. King, 1948, p. 48-49) is almost certainly in the Grayburg, but in the report the fossils collected there were not separated from those collected in the Goat Seep Dolomite and Queen Formation. Needham (1937, p. 56-58) described the fusulinid Parafusulina dunbari which was found near the middle of the Dog Canyon Limestone (of former usage, Grayburg Formation of this report) along Last Chance Canyon. According to Lloyd G. Henbest (written communication, Apr. 14, 1958), "this species $* * *$ seems to be synonymous with Parafusulina rothi Dunbar and Skinner, 1936" (Dunbar and others, 1935). No fossils were collected from the Grayburg during the present investigation.

Newell and others (1953, p. 41-42) identified the fusulinids Parafusulina maleyi and Rauserella erratica found in the upper part of the Queen Formation in sec. 32, T. 24 S., R. 23 E., near the abandoned CCC camp in Dark Canyon (stratigraphic section 12, pl. 3). Although not identified as to species on their faumal chart (p. 227-232), they also reported (p. 143) crinoids, echinoids, bryozoans, pelecypods, gastropods, scaphopods, and algae in the Queen. Kenji Konishi (oral communication, 1960), of the Geological Survey, iden- 
tified the algae? Gymnocodium sp. and Mizzia sp. in thin sections of samples of the Queen from North McKittrick Canyon (stratigraphic sections 20 and 21, pl. 3).

Fossils are rare or absent in the Seven Rivers, Yates, and Tansill Formations near their transition into the evaporite facies, but they become increasingly abundant toward the Capitan Limestone. Even where relatively abundant, however, the fossils are dolomitized and commonly fragmental. None were collected during the present investigation. P. B. King (1948, p. 79-82) has presented a summary of the paleontology of the Carlsbad Limestone of former usage which was comprised of the same rocks.

Fusulinids of the genus Polydiexodina are abundant in the Seven Rivers, Yates, and Tansill Formations near the Capitan Limestone and locally form fusulinid coquinas. Other fusulinid genera are present but are rare. Other than fusulinids, pelecypods, gastropods, and scaphopods are the most abundant fossils found in the upper three formations of the Artesia Group. Brachiopods are present, but are much scarcer than in the Capitan Limestone or equivalent rocks of the Delaware basin. Sponges, cephalopods, and trilobites have been found also, but they are not abundant.

P. B. King (1948, p. 79) listed a dozen species of algae that had been identified from the carbonate facies of Seven Rivers, Yates and Tansill (Carlsbad Limestone of former usage). In addition to these, Kenji Konishi, of the Geological Survey (oral communication, 1960), found Permocalculus sp. in a thin section of a sample from the base of the Seven Rivers Formation in North McKittrick Canyon (stratigraphic section 21, pl. 3). Some workers (Ruedemann, 1929, p. 1079-1080; Johnson, 1942, p. 213; Newell and others, 1953, p. 120) believe that the pisolites of the carbonate facies of the Artesia Group may be of algal origin.

\section{POST-PERMIAN DEPOSITS CRETACEOUS ROCKS}

No rocks of definite Cretaceous age crop out in the mapped area, but pebbles of limestone and sandstone containing marine fossils of early Washita (Early Cretaceous) age (Lang, 1947, p. 1472) are scattered on the Castile Formation along a side road 400 feet southeast of U. S. Highway 62 in N1/2 sec. 31, T. 25 S., R. 26 E. Lang (p. 1474) suggested that these Cretaceous rock fragments were "trapped *** in a deep sink or cavernous channel which later collapsed, and they have been preserved there while the enclosing rocks were eroded away." Inasmuch as solution features are common in the Castile Formation, the suggestion seems reasonable. Possibly other small areas of Cretaceous rock fragments are preserved in the Castile outcrop area, but no others have been found.

At several places along the top of the Reef Escarpment, joints in the Tansill Formation of Permian age are filled with quartzitic pebble-bearing sandstone dikes, and low areas on the ridge top resembling shallow sinks contain scattered quartz pebbles. The largest of the sandstone dikes were seen at the east rim of Slaughter Canyon in SW $1 / 4$ sec. 13 , T. 25 S., R. 23 E., near the Reef Escarpment and at the head of a small canyon in S1/2 sec. 7, T. 25 S., R. 24 E. Dikes at both of these localities contain rounded granules and pebbles of quartzite, and a 10-foot-thick dike at the latter locality contains pebbles of limestone and siltstone as well. Other sandstone dikes of this type occur in Jurnigan Draw in NW1/4 sec. 17, T. 24 S., R. 24 E. (fig. 22). Similar conglomeratic sandstone was also found at the head of Yucca Canyon in SW1/4 sec. 28, T. 25 S., R. 23 E., and on the ridge top in $\mathrm{NW}_{1 / 4}$ sec. $24, \mathrm{~T} .25 \mathrm{~S} ., \mathrm{R}$. $23 \mathrm{E}$. Scattered quartz pebbles were found at many localities along the top of the Reef Escarpment between the mouths of Rattlesnake and Double Canyons.

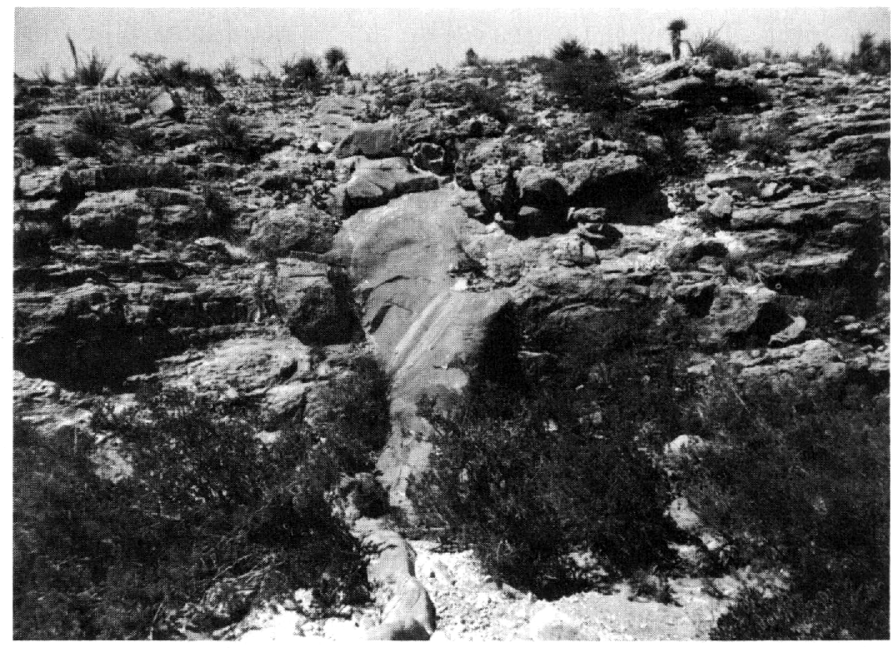

FigUR日 22.- Nearly vertical sandstone dike of probable Cretaceous age in the Capitan Limestone near its transition into the Tansill Formation in Jurnigan Draw.

Horberg (1949, p. 466) examined some of these deposits and pebble localities and believed they were Ogallala (Pliocene) in age. P. B. King (1948, p. $140)$, on the basis of geomorphic and stratigraphic evidence, suggested that Cretaceous rocks may once have covered the Guadalupe Mountains, although he saw no remnants of them in the southern part of the range. An outlier of Cretaceous rocks is present on the crest of the Sacramento Mountains (Pray and Allen, 1956, p. 2735 ) about 95 miles to the northwest. This outcrop contains marine fossils of Cenomanian (early Late 
Cretaceous) or latest Albian (late Early Cretaceous) age in a shale overlying pebble-bearing quartz sandstone 150 feet thick which is similar to the pebble-bearing sandstone in the present mapped area. This occurrence of Cretaceous rocks on top of the Sacramento Mountains to the northwest, the occurrence of fossils of early Washita age on the Castile Formation to the southeast of the Guadalupe Mountains, and the presence of rocks of Washita age overlying Permian rocks in the vicinity of the Cornudas Mountains (King, P. B., 1949) about 55 miles west-southwest, together suggest that the pebble-bearing sandstone and scattered gravel along the Reef Escarpment are remnants or slightly reworked deposits of a once-extensive blanket of Cretaceous rocks of probable Washita age.

\section{QUATERNARY DEPOSITS}

\section{GRA VEL OF PLEISTOCENE AGE}

Gravel, sand, and silt of probable Pleistocene age cover much of the Castile Formation, especially north and west of Black River. Most of the Mescal Wash area, south of Rattlesnake Canyon and west of Black River, is overlain by gravel that is as thick as 300 feet.

The northeastern part of T. 24 S., R. 26 E., is also covered by gravel that is at least 300 feet thick where penetrated by wells a few miles to the north. In both areas the gravel probably was deposited on an uneven erosion surface cut on the Castile Formation. Numerous gravel remnants occur at several levels between these two areas. The more conspicuous of these smaller comparatively thin deposits are shown separately on the geologic map (pl. 1), and some areas mapped as Castile Formation may be covered by low-level gravel of considerable thickness.

All the gravel deposits mapped consist of poorly sorted detritus ranging in size from silt to cobbles derived mostly from the Capitan Limestone and the carbonate facies of the Artesia Group. Quartzite pebbles probably derived from the Cretaceous rocks that presumably once covered the Guadalupe Mountains are also present in most of the gravel deposits. Most of the gravels are uncemented, but locally the upper surface has been consolidated by recent caliche. Scattered patches of gravel along Black River and below Blue Spring (sec. 33, T. 24 S., R. 26 E.) have been cemented by calcareous tufa of Recent age.

Relatively thin gravel deposits similar in composition to those on the Castile Formation cap most of the drainage divides in the Seven Rivers Embayment (fig. 1 ), but they were not mapped. Detritus in these deposits apparently was derived largely from the San Andres Limestone and from the Grayburg and Queen Formations in the Guadalupe Mountains.
Except for gravel of Recent age in modern arroyos in the Mescal Wash area, all the gravel deposits described above are older than those of the present erosion cycle and are tentatively assigned to the Pleistocene. Several cycles of erosion are suggested by the varying degrees of dissection and the different levels of the deposits. Horberg (1949, fig. 3) correlated the extensive gravel surface of the northeastern part of T. 24 S., R. $26 \mathrm{E}$., with the Orchard Park terrace as described by Fiedler and Nye (1933, p. 11-12) in the Roswell artesian basin about 20 miles north of the present area. The higher surfaces of the Mescal Wash were also tentatively correlated with the Orchard Park terrace by Horberg (1949, fig. 3). He correlated the dissected surface associated with the higher gravel remnants adjacent to the Reef Escarpment on both sides of White City to the older Blackdom terrace (Fiedler and Nye, 1933, p. 12), whereas he tentatively correlated most of the lower surfaces with the younger Lakewood terrace (Fiedler and Nye, 1933, p. 10-11). The dissected gravel surface of the Seven Rivers Embayment may represent the Blackdom terrace.

\section{ALLUVIUM}

Recent alluvial deposits border the larger drainage courses throughout the area, but the only ones mapped are those along Black River in the southeastern part of the area, and in Shattuck Valley, Dog and Upper Dog Canyons, and the Salt Flat in the western part. Elsewhere, the alluvial deposits have limited extent and are not shown on the geologic map (pl. 1).

The composition of all the alluvial deposits reflects the local bedrock. Finely divided gypsum comprises most of the alluvium in drainage courses on the Castile Formation, such as Cottonwood Draw, Ben Slaughter Draw, and Hay Hollow. Gypsum and limestone detritus make up most of the alluvium along Black River. Alluvium in the western tributaries of Black River consists of poorly sorted silt- to pebble-sized limestone detritus and minor quartz silt and sand derived from the Capitan Limestone and Artesia Group. The lower reaches of most of the larger canyons in the Reef Escarpment, from Big Canyon on the southwest to Elbow Canyon on the northeast, are floored with coarse detritus, as large as boulder size, derived from the same source. The large northeastward-trending canyons of the Guadalupe Mountains from Dark Canyon on the southeast to Siegrest Draw on the northwest contain poorly sorted coarse rubble derived from the bedrock along the upper reaches of the canyons. The lower reaches of these canyons in the Seven Rivers Embayment contain alluvium from the same sources, but the constituent fragments are smaller. Shattuck Valley, Dog and Upper Dog Canyons, and the Salt Flat all con- 
tain rather broad, but apparently relatively thin, alluvial deposits consisting predominantly of clay- to sand-sized detritus derived chiefly from the Yeso Formation, the San Andres Limestone, and the Grayburg and Queen Formations.

\section{calcareous tufa}

Calcareous tufa deposits are common where springs issue from carbonate beds or carbonate gravel deposits. The largest accumulations of tufa are in the Last Chance Canyon drainage and along Black River valley.

The largest single accumulation of tufa in the area is below Sitting Bull Spring (NE1/4 sec. 9, T. 24 S., R. $22 \mathrm{E}$.). This deposit covers the bottom of Sitting Bull Canyon for a distance of three-fourths of a mile and ends abruptly in a 1,000-foot-wide and nearly 200 -foothigh cliff over which the water from Sitting Bull Spring drops in a narrow waterfall (fig. 23). A similar but smaller tufa deposit is present in White Oaks Canyon below White Oaks Spring (SW1/4 sec. 5, T. 24 S., R. 22 E.).

Of numerous tufa accumulations along Black River valley, the largest are in the river, below Rattlesnake and Blue Springs, and at Black River Village. The tufa of Black River and environs cements the gravel deposits of the river.
The calcareous tufa deposits represent calcium carbonate precipitated from very limy spring water that lost carbon dioxide as it was warmed by the atmosphere, thus decreasing the solubility of calcium carbonate. Although algae, which use the carbon dioxide in the water, are often abundant in the spring-fed pools on the tufa, it is not known how important a part they play in the precipitation of the calcium carbonate. They probably contribute in a small way.

\section{TERTIARY IGNEOUS ROCKS}

Three igneous dikes occur in the Castile Formation in secs. 11,14 , and 15, T. 26 S., R. 24 E., just west of U.S. Highway 62 . The dikes strike about N. $60^{\circ}$ E., dip about $80^{\circ} \mathrm{N}$., and are 1,000 to 4,000 feet long on the outcrop. The dikes are more easily detected on vertical aerial photographs than on the ground where they generally appear as linear zones of brown-weathering soil. At one place near the west end of the northern dike, relatively fresh rock is exposed in a gully. Here, the dike is 6 to 7 feet thick. The rocks of the Castile Formation adjacent to the dike show no apparent alteration. The dike is made up of a fine-grained vesicular rock identified as alkali trachyte by $\mathrm{P}$. H. Masson (Pratt, 1954, p. 143). Fragments of similar rock, iden-

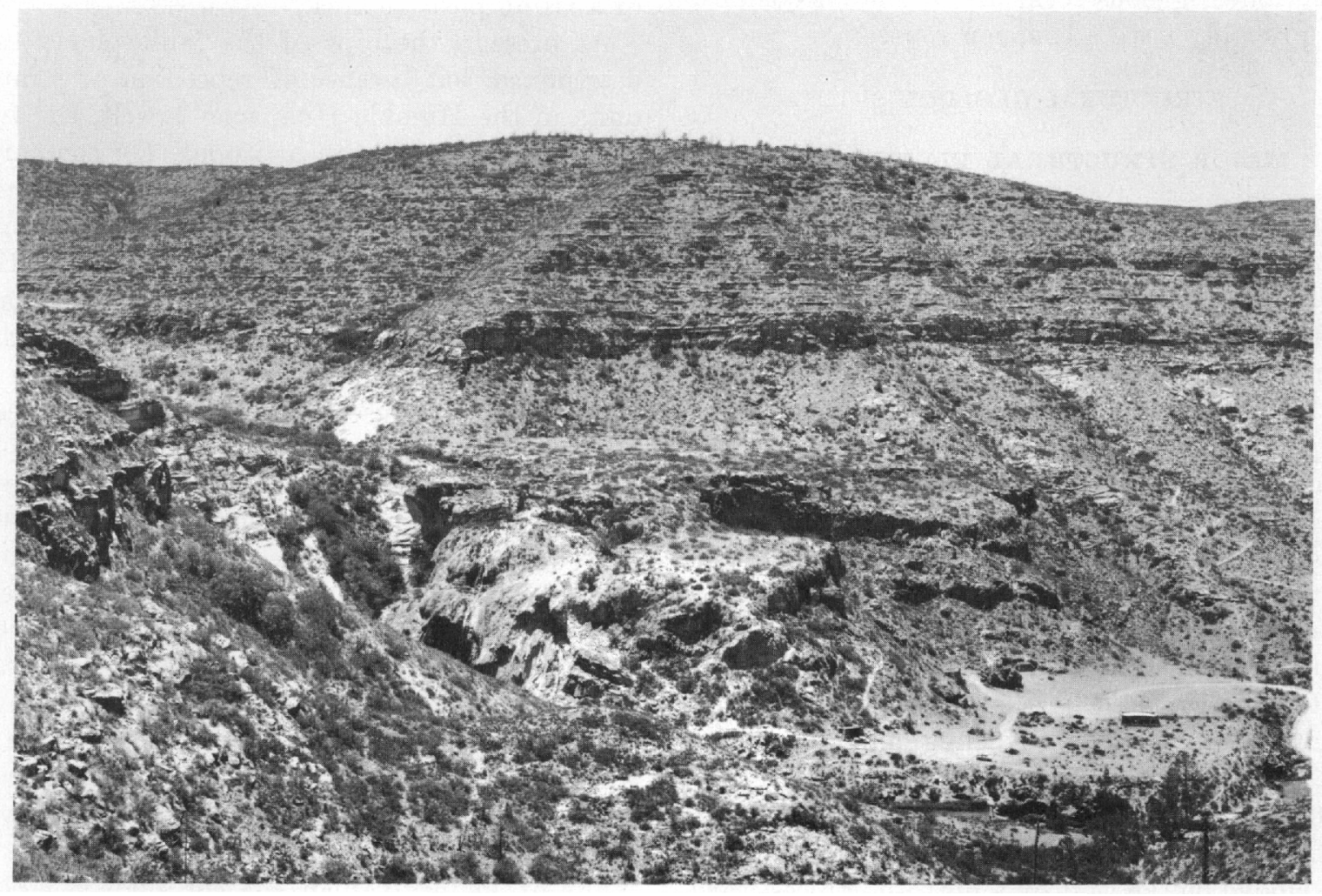

Figure 23.-Calcareous tufa at Sitting Bull Falls. Rock picnic shelters and automoblles at lower right provide scale. Falls are visible as a small trickle near left edge of tufa dam. Sitting Bull Spring, out of vlew up the canjon, issues from tongue of the San Andres Limestone. 
tified by Masson (Pratt, 1954, p. 146) as trachyandesite, are scattered on the surface about 1,000 feet southeast of U.S. Highway 62 in NE1/4 sec. 31, T. 25 S., R. 25 E. These fragments were probably eroded from a dike or sill and perhaps were trapped in a sinkhole or solution channel in the Castile Formation in much the same way as the Cretaceous rock fragments discussed on page 37. Igneous rock is not known to occur elsewhere in the mapped area. The igneous rocks are post-Castile in age, and by analogy with igneous rocks of similar composition and known age found in many parts of southern New Mexico and western Texas they are probably Tertiary in age.

Other bodies of igneous rock are present in nearby areas. A small plug in the Bell Canyon Formation crops out about 15 miles to the southwest (fig. 24). The rock in this plug was tentatively identified by P. B. King (1948, p. 103) as trachyte. According to Pratt (1954, p. 146), this plug is on one of several low northnorthwest-trending ridges of altered sandstone. Another nearby occurrence of igneous rock is a sill 410 feet thick in Carboniferous rocks at a depth of 8,730 feet in the Magnolia Homer Cowden 1 well about 14 miles south-southwest of the 3 dikes in the present mapped area. This sill rock was identified by Flawn (Pratt, 1954, p. 147) as leucosyenodiorite. All the above-mentioned igneous rocks are of similar composition and probably have a common source.

\section{STRUCTURAL GEOLOGY}

MAJOR STRUCTURAL ELEMENTS

The principal structural feature of the report area is the Guadalupe Mountains uplift (fig. 24). This uplift may be generally described as a gently northeastward tilted block bounded on the west by a zone of nearly en echelon normal faults of late Cenozoic age and on the east by a monoclinal fold of Cenozoic age, the Huapache monocline. The monocline apparently is superimposed on a zone of late Paleozoic thrust faults. The southeast margin of the Guadalupe Mountains uplift coincides with the Reef Escarpment which may have resulted partly from Cenozoic rejuvenation of a late Paleozoic fold, the Bone Spring monocline. Adjacent to this monocline on the northwest is a zone 5 miles wide characterized by the broad northeastwardplunging Walnut Canyon syncline and Guadalupe Ridge anticline.

West of the Guadalupe Mountains is a graben area occupied by Big Dog and Upper Dog Canyons. This area is bounded on the west by a north-northwestwardtrending zone of normal faults of late Cenozoic age in and adjacent to the Brokeoff Mountains. Only the ex- treme north end of this fault zone lies in the report area.

Strata to the northeast and southeast of the Guadalupe Mountains are relatively undisturbed and, in general, dip gently east to northeast.

\section{OLDER STRUCTURAL FEATURES}

\section{HUAPACHE THRUST ZONE}

The only pre-Permian structural element known in the report area is a buried fault zone along the east side of the main Guadalupe Mountains block. The displacement, attitude, trend, and age of the fault zone are suggested by $\operatorname{logs}$ of deep oil tests drilled in the Guadalupe Mountains and the Seven Rivers Embayment. One well, the Humble Huapache 1 (sec. 35, T. 23 S., R. 22 E.) on the east flank of the Guadalupe Mountains, penetrated at least two and possibly as many as five faults. The nature and thickness of Mississippian, Pennsylvanian and Lower Permian rocks penetrated in several other wells indicate that the fault zone is very nearly coincident with the present east boundary of the northern Guadalupe Mountains, that it was apparently intermittently active through all or most of Pennsylvanian time and possibly Early Permian time, and that the fault zone defined the east boundary of a rising positive area.

At present, the dips of the fault planes cannot be determined, but because of repetition of stratigraphic units in the Humble Huapache 1 well, the faults are known to be reverse in attitude. By comparing logs of two wells drilled to the west and to the east of the fault zone (Union White 1 and Humble Huapache 2), it is apparent that rocks on the west sides of the faults are upthrown. Comparison of the Continental-Standard of Texas Bass 1 and the Continental East Texas Hill 1 establishes the strike of the fault zone as about N. $35^{\circ} \mathrm{W}$. Because no faults were detected in the Humble Huapache 2 it is unlikely that the fault planes dip at a low angle. They apparently dip westward $45^{\circ}$ to $85^{\circ}$. Abnormal thicknesses of stratigraphic units above and below the major faults found in the Humble Huapache 1 indicate that the rocks are dipping eastward as much as $60^{\circ}$, and possibly much more, throughout a vertical interval of nearly 4,000 feet. Because this seems excessive for drag folding along a fault, the dipping rocks are interpreted to be part of a thrusted fold. The fault zone could be a normal fault zone which was later folded and overturned early in Permian time, but this seems unduly complicated. Thrust faults of Pennsylvanian age cut surface rocks in the Marathon uplift (King, P. B., 1937, p. 134-136), 160 miles to the southeast (fig. 3), and reverse faults may 


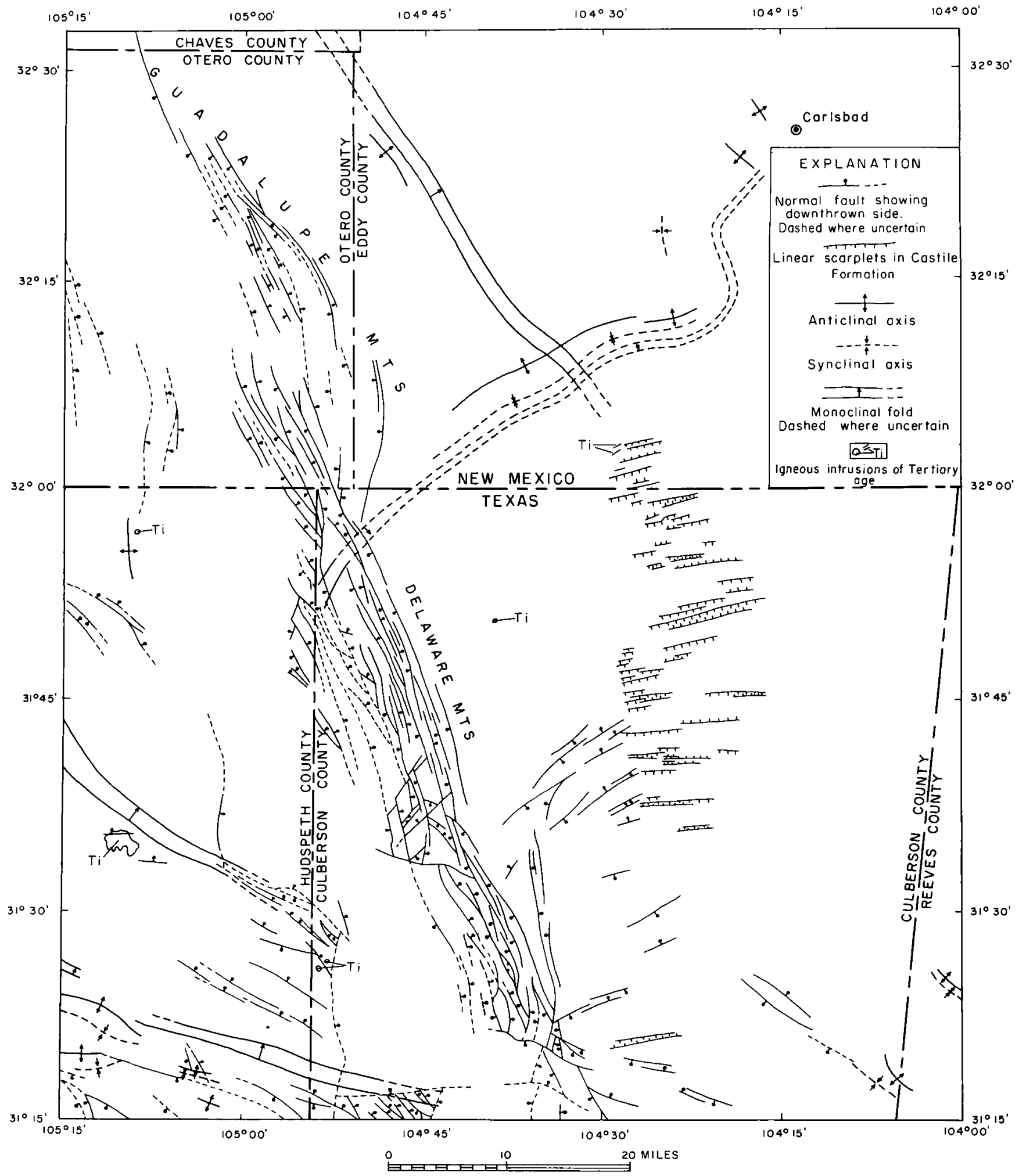

Figure 24.-Tectonic map of Guadalupe Mountains regton, New Mexico and Texas. Texas part of map adapted from P. B. K1ng (1949). 
be present as close as 70 miles northwest in the Sacramento Mountains (G. O. Bachman, oral communication, 1959). These faults indicate that the entire region was subjected to compressional forces during Pennsylvanian time.

Mississippian rocks underlying the area show no important lithologic change from one side of the fault zone to the other, but they are vertically displaced by as much as 4,000 to 6,000 feet and are found twice in the Humble Huapache 1 well; therefore, the faulting must be post-Mississippian in age. On the other hand, the Permian San Andres Limestone, which lies at the surface over the fault zone, is not ruptured; so the faulting must be pre-Guadalupe in age.

Pennsylvanian rocks in a sequence about 1,800 feet thick were found in the Union White 1 well on the west or upthrown side of the fault zone and a Pennsylvanian section, nearly 4,500 feet thick, was found in the Humble Huapache 2, drilled on the downthrown side of the fault zone. The rocks in both wells are reported to contain fusulinids ranging in age from Early to Late Pennsylvanian. Slow but continuous movement or slight intermittent movements along the faults could have kept the area to the west near effective wave base so that it received less than half as much sediment as the area to the east. If all or nearly all the movement on the faults took place within a relatively short interval of time, the upthrown fault block would probably have been raised above sea level and eroded, and the rocks would not contain a complete sequence of fusulinids.

The Hueco Limestone and Yeso Formation of Wolfcamp and Leonard age are both thinner on the west side of the fault zone than on the east side, indicating that some movement on the faults probably persisted into Early Permian time. In the Continental East Texas Hill 1 well, drilled about 2 miles east of the fault zone, a 2,200-foot sequence of rock is reported to contain anomalously mixed Late Pennsylvanian and Early Permian fusulinids. This suggests that movement took place in the fault zone near the close of Pennsylvanian time and (or) early in Permian time, and that Late Pennsylvanian fusulinids which had been deposited on the uplifted west side of the fault zone were locally eroded and transported eastward early in Permian time.

The fault zone is reflected today on the surface by the low eastward-dipping Huapache monocline. Inasmuch as the Huapache monocline affects rocks of late Guadalupe age, it appears that minor post-Guadalupe, probably Tertiary, movement has taken place along the old zone of weakness.

Vertical movement along the Huapache thrust zone was apparently greater in the vicinity of Texas Hill than it was to the south near Last Chance Canyon. Near Last Chance Canyon 1,500 to 2,000 feet of Pennsylvanian rocks are present on the upthrown side of the fault zone in the Union White 1 and the Humble Huapache 1 and 3 wells. On the other hand, in the Continental-Standard of Texas Bass 1 drilled on Texas Hill, no Pennsylvanian rocks were found. The presence of Late Pennsylvanian fusulinids mixed with Early Permian fusulinids in the Continental East Texas Hill 1 may indicate that some Pennsylvanian sediments were deposited in the area now occupied by Texas Hill, but later movement along the fault zone raised the area above the base level and all Pennsylvanian rocks and several hundred feet of Mississippian rocks were removed by erosion (section $A-A^{\prime}$, pl. 1). Even greater uplift is indicated northwest of Texas Hill. In the Standard of Texas Scarp Unit 1 (sec. 18, T. 21 S., R. 18 E.), 8 miles west of the northwest corner of the mapped area, all Mississippian and Pennsylvanian rocks are missing, and a very thin section of Hueco Limestone rests directly on Devonian rocks.

How far southeast of the Last Chance Canyon area the thrust zone extends is not known. The fact that the reported thickness of the sequence from the base of the Mississippian System to the top of the Leonard Series in the Superior Federal 1-134 well (sec. 12, T. 26 S., R. 24 E.) is nearly 3,000 feet less than the same sequence in the Gulf Estill 1-AD (sec. 29, T. 24 S., R. 26 E.) suggests that the former well was drilled over a buried highland. The Huapache thrust zone may well extend into the Delaware basin between the two wells.

The Pennsylvanian positive area to the west of the Huapache thrust zone may be a southeastward extension of the Pedernal land mass of Torrance County, described by Thompson (1942, p. 12), or it may be one of a chain of smaller positive elements (fig. 3 ). As shown by Foster (1959), in most wells drilled in the eastern foothills of the Sacramento Mountains northwest of the present report area, Pennsylvanian rocks are either thin or missing. In the Sierra Diablo, about 60 miles to the south, a positive area is present in which Permian rocks rest on rocks ranging in age from Precambrian to Pennsylvanian (King, P. B., and Knight, J. B., 1944). The position and nature of the west edge of the positive element or chain of elements in the latitude of the report area cannot be determined aceurately at present.

\section{BONE SPRING MONOCLINE AND BONE SPRING ARCH}

Late in Leonard time and early in Guadalupe time, a broad southeastward-dipping fold, the Bone Spring monocline, formed along the basinward edge of the 
Victorio Peak Limestone. The folded rocks are not exposed in the report area, but they are exposed near the south end of the Guadalupe Mountains in Texas. The fold has been described by P. B. King (1948, p. 18-19). The monocline is presumed to continue northeastward beneath the surface of the mapped area where it is believed to form the southeast flank of an arch 15 to 20 miles wide. Blanchard and Davis $(1929$, p. 964) apparently had such a feature in mind when they originally named the "Bone Springs" arch, but their interpretations of the stratigraphy adjacent to the northwest side of the arch differ from those presented here.

In his description of the effects of the Bone Spring monocline on Permian sedimentation, P. B. King (1948, p. 19) stated that the "upraised limestones were being eroded in early Delaware Mountain time, and the Brushy Canyon formation of that group overlaps their sloping surface. The overlap is so great that 1,000 feet of beds, the entire Brushy Canyon formation, is cut out." In areas to the northwest of the monocline, the contact between the Cutoff Shale and the sandstone tongue of the Cherry Canyon Formation is apparently an unconformity representing all Brushy Canyon time. The unconformity present at the base of the sandstone tongue of the Cherry Canyon Formation in Last Chance Canyon (stratigraphic section 9, pl. 3) is probably a continuation of that unconformity, and rocks of Brushy Canyon age are apparently absent there. However, as shown on page 28 , about 580 feet of rock in the middle part of the San Andres Limestone on Algerita Escarpment is apparently of Brushy Canyon age. A northwest flank of the Bone Spring arch is thus implied although direct evidence for its existence has not been observed. If present, the northwest flank should be exposed on the Big Dog Canyon scarp somewhere in T. 24 S., R. 20 E., but Tertiary faulting and slumping have obscured the relations.

The Bone Spring arch was almost completely buried by the close of Brushy Canyon time, and it had little effect on sedimentation during most of early Cherry Canyon and late San Andres time. Near the end of San Andres time, however, a narrow subsidiary arch formed near the northwest flank of the main Bone Spring arch. This subsidiary arch is indicated by the slight angular unconformity between the San Andres Limestone and overlying Grayburg Formation in Last Chance Canyon (stratigraphic sections 1, 7, 8, 9, pl. 3). An unconformity at the same stratigraphic position occurs near Berlin Tank in the southern part of the Brokeoff Mountains (Hayes, 1959, p. 2211) and is probably due to erosion on an extension of the same small arch. Blanchard and Davis (1929, pl. 11) show what may be the same subsidiary arch as the Tank Canyon arch near the north- west edge of their "Bone Springs" arch. The subsidiary arching ceased by the beginning of Grayburg time, and the Grayburg Formation was deposited across the fold with no apparent thinning.

The Bone Spring flexure was probably slightly rejuvenated at about the same time as the subsidiary arch formed. The resultant southeast-facing dipslope on the sandstone tongue of the Cherry Canyon Formation thus formed an accentuated northwest margin for the Delaware basin. This accentuated basin margin had a profound control on later Permian sedimentation.

\section{CENOZOIC STRUCTURAL FEATURES}

\section{FoLDs}

Two systems of folds involving the San Andres Limestone and Artesia Group at the surface interrupt the northeastward regional dip of about $1^{\circ}$ to $2^{\circ}$. These are the north-northwestward-trending Huapache monocline and its related structures and the northeastwardtrending folds that parallel the Reef Escarpment on its northwest side. In addition to these are folds related to faults in the Brokeoff Mountain-Big Dog Canyon area and other minor irregularities, some of which are probably solution and collapse features.

The east-northeastward-dipping Huapache monocline is a prominent fold that extends from the Reef Escarpment between Rattlesnake and Slaughter Canyons to a point beyond the north edge of the mapped area (pl. 1; fig. 24). It may also extend southeastward across the older Bone Spring monocline into the Delaware basin. It resulted from post-Permian flexing along the trend of the late Paleozoic Huapache thrust zone. Maximum dips along the monocline in the San Andres Limestone and younger rocks that form the surface generally range from $5^{\circ}$ to $8^{\circ}$. The width of the fold is generally less than 2 miles, and the difference in elevation of equivalent beds on opposite sides is about 1,000 feet.

Closely associated with the Huapache monocline is the asymmetrical Texas Hill dome. Its axis is parallel to the trend of the Huapache monocline, and the relatively steep east flank of the dome merges with the monocline. The west flank of the dome is formed by a slight reversal of the gentle regional dip. The total structural closure on the dome at the surface is apparently less than 100 feet. The crest of the structure is at about the summit of Texas Hill.

The folds that parallel the Reef Escarpment on its northwest side may also be indirectly related to an older structural feature, the Bone Spring monocline of Early Permian age. As stated above, the Bone Spring monocline may have controlled the position of the Capitan 
Limestone. An original sedimentary dip of $20^{\circ}$ to $30^{\circ}$ in the reef breccia beds of the Capitan Limestone has apparently been increased as much as $10^{\circ}$ by Cenozoic tectonism. The tectonic component of dip on the Reef Escarpment forms the southeast flank of a long sinuous anticline whose gently dipping northwest limb is the southeast limb of the northeast-plunging Walnut Canyon syncline (pl. 1; fig. 24). The Walnut Canyon syncline, whose axial trace is about 1 mile northwest of the crest of the Reef Escarpment, extends from Big Canyon to near the mouth of Walnut Canyon, a distance of nearly 25 miles. The maximum dips on the northwest flank of the syncline average $6^{\circ}$ and locally are as great as $9^{\circ}$; the southeast flank rarely dips more than $1^{\circ}$ or $2^{\circ}$. For much of its length, the axial trace of the Walnut Canyon syncline nearly coincides with West Slaughter, South Rattlesnake, and Walnut Canyons. The steeper northwest limb of the Walnut Canyon syncline is the southeast limb of the asymmetrical northeastplunging Guadalupe Ridge anticline whose axial trace is near the crest of Guadalupe Ridge. Dips on the north west limb of this anticline are also very gentle and barely exceed $1^{\circ}$. The structural contours indicate one more indistinct shallow, northeast-plunging syncline adjacent to the Guadalupe Ridge anticline on the northwest. These folds that parallel the Reef Escarpment are presumed to be Laramide in age. They are obviously post-Permian inasmuch as they affect Permian rocks, and apparently they antedate the development in early and middle Tertiary time of Carlsbad Cavern, for the open joints that controlled the solution of the limestone are probably tension joints that formed during the folding.

Other small undulations in the carbonate surface rocks in the northern part of the Guadalupe Mountains, as shown on the geologic map (pl. 1), are probably tectonic in origin. Undulations in the outcrop areas of the evaporite member of the Seven Rivers Formation and the Castile Formation are probably at least partly due to solution and collapse of evaporite beds.

\section{FAUTTS}

Many closely spaced faults trend north to northwest along the west edge of the geologic map area (pl. 1). Several faults of small displacement also parallel the Reef Escarpment, but only one near White City was considered of sufficient magnitude to show on the map. Linear features in the Castile Formation may be faults of small displacement and are described on page 46 .

The faults on the west side of the area are assigned to three groups: (a) those along the Guadalupe Mountains scarp north of Stone Canyon, (b) those parallel to the
Shattuck Valley scarp south of Stone Canyon, and (c) those in and north of the Brokeoff Mountains.

The Guadalupe Mountains scarp from Stone Canyon northward is characterized by numerous closely spaced high-angle faults which are parallel or subparallel to that scarp. Dip slip is probably predominant. Nearly all these faults are downthrown on the west, but a few short faults have the opposite displacement. Only one of the latter kind, in the northeastern part of T. $25 \mathrm{~S}$., R. 20 E., is shown on the geologic map (pl. 1). It was possible to measure accurately the dips of only 2 faults, which were $86^{\circ}$ and $87^{\circ} \mathrm{W}$. The traces of these faults suggest that all but those near the north end of the scarp dip at high angles. Toward the north the principal faults in the searp may dip as low as $60^{\circ}$ to the west. Stratigraphic displacements of faults high on the scarp rarely exceed 100 feet, but 2 faults that are mostly buried beneath alluvium in Big Dog Canyon have maximum stratigraphic displacements of about 800 feet where they are exposed low on the scarp. A group of en echelon faults between Sixshooter and Stone Canyons dies out southward into a relatively steep westdipping flexure that forms the east side of a syncline occupied by the lower end of Upper Dog Canyon. Near the north end of the mapped part of the scarp, the largest fault apparently splits into a series of "horsetail" faults of smaller displacement. These faults, like those farther south on the scarp, are mostly high-angle dipslip faults downthrown on the southwest from a few feet to at least 300 feet. Beds in fault slices near Sixshooter Canyon and at the north edge of the mapped area in the Guadalupe Mountains scarp dip away from the mountains so that, in effect, the scarp is a faulted monoclinal fold, whereas between these two areas the beds in the fault slices dip mountainward, suggesting that some of the displaced blocks may be large landslides.

The faults paralleling the Shattuck Valley scarp are separated from the faults at the south end of the main Guadalupe Mountains scarp by an unfaulted monoclinal fold about $11 / 2$ miles wide. Most of the displacement on the Shattuck Valley scarp is along one long fault high in the scarp, although some displacement is taken up by a smaller fault. The larger fault can be traced for about 13 miles from north of El Paso Gap southward into a fault which P. B. King (1948, pl. 20) called the Dog Canyon fault. It has an arcuate trace convex to the east, and the average strike is a little east of north. The fault plane was nowhere seen, but it probably dips to the west at a high angle. Stratigraphic displacement along the fault is as much as 800 feet locally. Adjacent to the fault, beds on the down- 
dropped side dip sharply to the west with dips as great as $70^{\circ}$ and are cut by strike faults of small displacement (Boyd, 1958, p. 56). None of these small faults are shown on the geologic map (pl. 1). The steep westward-dipping beds on the west side of the fault flatten out under the alluvium of Shattuck Valley and, on El Paso Ridge on the west side of the valley, the dip is as much as $14^{\circ}$ to the east, thus forming a syncline. On the west side of Upper Dog Canyon near the southwest edge of the mapped area is another arcuate fault, downthrown on the east, which parallels the fault on the Shattuck Valley scarp. Upper Dog Canyon, therefore, is a combination graben and syncline.

The faults in and north of the Brokeoff Mountains are a closely spaced complex of northwestward-striking faults, most of which are downthrown on the east side. A few faults, particularly toward the north, are downthrown on the west so that the area contains several narrow grabens and horsts. Stratigraphic displacement on the faults range from a few feet to as much as 600 feet. Two of the fault planes dip $60^{\circ}$ and $80^{\circ}$; dips of the others could not be measured. Most of the faults appear to be normal faults that dip at high angles. The Brokeoff Mountains fault zone and the main fault zone of the Guadalupe Mountains are separated by a graben occupied by Big Dog Canyon (pl. 1 ; fig. 25). Just beyond the west edge of the mapped area the two fault zones merge and form a profusion of subparallel faults along the Guadalupe Mountains scarp.

Relatively steeply dipping strata in the northern part of the Brokeoff Mountains and the central part of the Guadalupe Mountains scarp owe their dip to their inclusion in tilted fault slices. Dipping strata on the west side of the Dog Canyon fault and at the north and south ends of the Guadalupe Mountains scarp may be attributed to drag folding, at least in part. Folded and inclined strata on the east side of Martine Ridge, on El Paso Ridge, on the west side of Upper Dog Canyon, and elsewhere, however, cannot be so easily related to faulting. It is possible that either mild compressive forces from the northeast or southwest, or differential uplift perhaps due to faulting in the subsurface, produced a broad anticline in the position of the Brokeoff Mountains, a syncline or series of en echelon synclines in the position of Big Dog and Upper Dog Canyons, and slight warping of the Huapache monocline. The system of normal faults on the west side of the Guadalupes may have formed perhaps as a result of release of compression or a result of uplift. In the Texas part of the Guadalupe Mountains, P. B. King (1948, p. 125) reported no evidence of compression at the surface and suggested that-

the Guadalupe and Delaware Mountains may have arisen as a result of deep-seated compression, manifested at the surface by essentially vertical uplift, which put the surface rocks under tension, thereby producing along the crest of the uplifted region an extensive system of tension joints and normal faults.

On the basis of his detailed studies and regional considerations, P. B. King (1948, p. 125) dated the normal faults of the Guadalupes as late Pliocene and early Pleistocene.

The short normal faults of very small displacement parallel to the Reef Escarpment, such as the one mapped in Walnut Canyon near White City, probably originated as tension joints on the crest of the narrow anticline adjacent to the Reef Escarpment.

\section{JOINTS}

No systematic study of joints was made, but some of the jointing observed is of special interest.

The Capitan Limestone and adjacent parts of the Artesia Group contain a conspicuous system of nearly vertical joints that parallel the Reef Escarpment. Associated with these are less conspicuous joints that trend at right angles to the Reef Escarpment. These intersecting joints formed the avenues for solution of such caves as Carlsbad Cavern and New, Goat, and Lechuguilla Caves. (See table 1.) Many of the joints parallel to the Reef Escarpment contain sandstone dikes of probable Cretaceous age, described on page 37. Numerous small drainage courses are controlled by this set of joints. Among these are Calamity Cove and Lefthook, Yucca, Nuevo, and Fence Canyons.

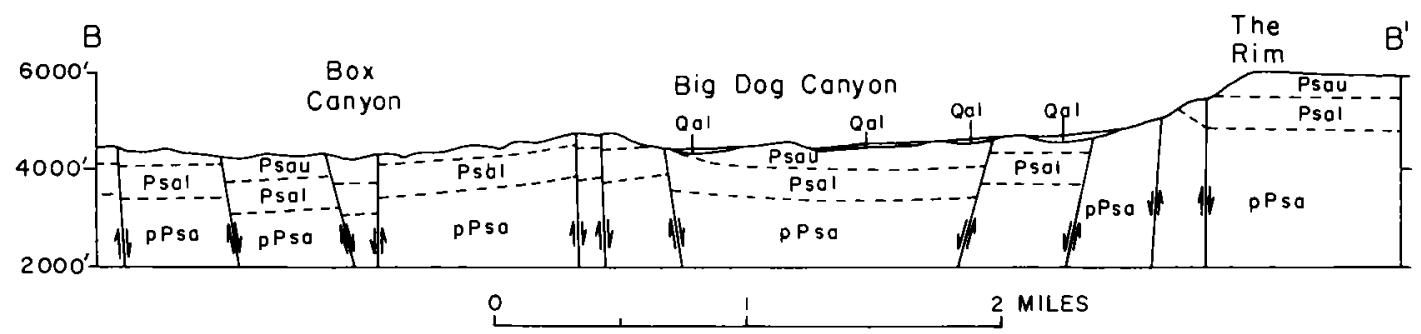

Figdre 25.-Section $B-B^{\prime}$ across Big Dog Canyon. (See pl. 1 for line of section.) Qal, alluvium; Psau, upper member of San Andres Limestone; Psal, lower cherty member of San Andres Limestone; pPsa, pre-San Andres rocks. 
The fact that these joints are everywhere parallel or at right angles to the Reef Escarpment, no matter what its trend, suggests a relation between the Capitan Limestone and the joints. Sandstone dikes of probable Cretaceous age in some of the joints indicate that they were opened before late Early Cretaceous time. Possibly they were formed soon after deposition of the Permian rocks by differential compaction of rocks in the Northwest-shelf area and the Delaware basin, or they may have been formed during post-Permian regional uplift by tensional stresses resulting from differential movement between the shelf and the basin. Some of the joints may have been enlarged and others may have formed concurrent with the folding of the Walnut Canyon syncline and related structures in Tertiary time.

Another type of jointing that is peculiar to the Capitan Limestone is sheeting parallel to the present erosion surface. Sheeting occurs locally along the Reef Escarpment and on the walls of some of the canyons which cut through the escarpment. The sheeting can be easily confused with the crudely developed bedding in the breccia member, which is subparallel to the surface of the Reef Escarpment. The type of sheeting or exfoliation noted in the Capitan Limestone is often well developed in granitic rocks, but it is rarely observed in sedimentary rocks. Similar jointing in massive sandstones of the Colorado Plateau was described by Bradley (1958, p. 1724).

Other joints in the area are more obviously directly related to structural features of Tertiary age. Along the west edge of the area are numerous closely spaced joints parallel to the faults there. These are particularly prominent along The Rim on the west edge of the Guadalupe Mountains. Less closely spaced joints of north-northwesterly trend are present in limestone and dolomite throughout the Guadalupe Mountains.

\section{LINEAR FEATURES IN CASTILE FORMATION}

Low scarps in the Castile Formation trend about $\mathrm{N}$. $75^{\circ}$ E. across the Yeso Hills in the southwestern part of the Castile outcrop area. Some of the scarps are several miles in length and are as high as 50 feet. They face south or north and bound relatively flat valleys or ridges that resemble horsts or grabens ranging from a few hundred feet to more than a mile in width. Such linear features are present in the Castile Formation for nearly 30 miles south into T'exas; they were mapped by $\mathrm{P}$. B. King (1949) and described in detail by Olive (1957).

The scarps are apparently the traces of shallow faults of small displacement. Olive (1957) has described the grabens between the scarps as "solution-subsidence troughs." He believes that gypsum is dissolved along underground drainage channels following fractures that closely parallel the regional dip direction and that when the roofs over the channels can no longer be supported, collapse ensues. In Olive's words (p. 357)-

The collapse debris forms a barrier across the channels and causes the underground drainage to seek passage * * along near-by fractures, which also approximate the trend of the regional dip. Subsidence that gives rise to troughs probably is not the result of a single cavern but of several.

The presence of small caverns and sinks, the irregular topography in the troughs, and the existence of gypsiferous springs (Ben Slaughter, Cottonwood, and Jumping Springs) to the east of the troughs in a downdip direction all support Olive's theory on the origin of the troughs.

\section{GEOMORPHOLOGY}

Most of the mapped area lies in the Sacramento section of the Basin and Range physiographic province as defined by Fenneman (1931, p. 393-395), but the relatively low area southeast of the Reef Escarpment is a part of the Pecos section of the Great Plains province (Fenneman, 1931, p. 47-50). Throughout the area the youthful to mature topography is directly related to the structure and character of the underlying rocks, but in places the topography may be partly controlled by an old superimposed drainage system. An extensive limestone cavern system that was developed during an earlier erosion cycle has been partly exhumed by the modern drainage system.

\section{MAJOR LANDFORMS}

The Guadalupe Mountains are a moderately dissected plateau which is gently inclined to the northeast. The inclination results from the regional dip of the rocks. The west margin of the mountains is formed by the Big Dog Canyon and Shattuck Valley fault scarps, whereas the northeast margin is formed by the dip slope on the Huapache flexure. The southeast edge of the mountains is marked by the Reef Escarpment, held up by the resistant Capitan Limestone.

The topography of the Dog Canyon-Brokeoff Mountains area is controlled primarily by faults and folds. Big Dog Canyon is a graben. Upper Dog Canyon and Shattuck Valley are, in effect, synclinal grabens, whereas the Brokeoff Mountains are basically an anticlinal horst.

Seven Rivers Embayment (fig. 1) is a topographic depression controlled by structure and differential erosion. On the west is the Huapache monocline defining the margin of the Guadalupe Mountains. On the southeast and east are the Hess Hills, Azotea Mesa, and Seven Rivers Hills (fig. 1), all capped by dolomite tongues in the evaporite facies of the Seven Rivers For- 
mation. North and west of those hills, where dolomite tongues were thin and scarce, the Seven Rivers Formation and much of the relatively nonresistant Queen Formation have been removed by erosion, leaving a topographic embayment.

The relatively low terrain of the Pecos section southeast of the mountains is carved from the easily eroded evaporites of the Ochoa Series. The Reef Escarpment rises above the plains primarily because of its greater resistance to erosion.

\section{DRAINAGE}

The drainage pattern in the mapped area is inherited in part from an ancestral drainage system, and like the topography, is closely controlled by the structure and the resistance to erosion of the surface bedrock. The ancestral drainage system was probably established early in Tertiary time after regional uplift, slight tilting to the northeast, and Laramide folding of the rocks adjacent to the Capitan Limestone.

Most of the major northeastward-flowing streams such as Black River, and those in Last Chance and Dark Canyons, and Rocky Arroyo, probably originated early in Tertiary time. Another consequent Tertiary stream, here called Walnut Creek, probably flowed northeastward along the axis of Walnut Canyon syncline between Dark Canyon and Black River.

Following uplift of the Guadalupe-Delaware Mountains block probably in late Pliocene or early Pleistocene time, soft and soluble rocks southeast of the Capitan Limestone were quickly eroded and the Reef Escarpment was exhumed. Headward erosion of consequent streams flowing off the Reef Escarpment then cut into the old Walnut Creek, which trended northeastward parallel to the reef, and diverted the stream flow southeastward at many points. West Slaughter and South Rattlesnake Canyons and the upper ends of Walnut and Wood Canyons were established by old Walnut Creek. Meanders that had developed in the mature older streams were incised during the uplift of the mountains to produce such features as the Serpentine Bends of Dark Canyon (fig. 26). Thus, the dendritic drainage pattern and meanders in the mountains from Dark Canyon northwestward probably are inherited also from the early Tertiary drainage system. To the southeast the Tertiary drainage has been largely destroyed by headward erosion of drainage off the Reef Escarpment. The sharp westward bends

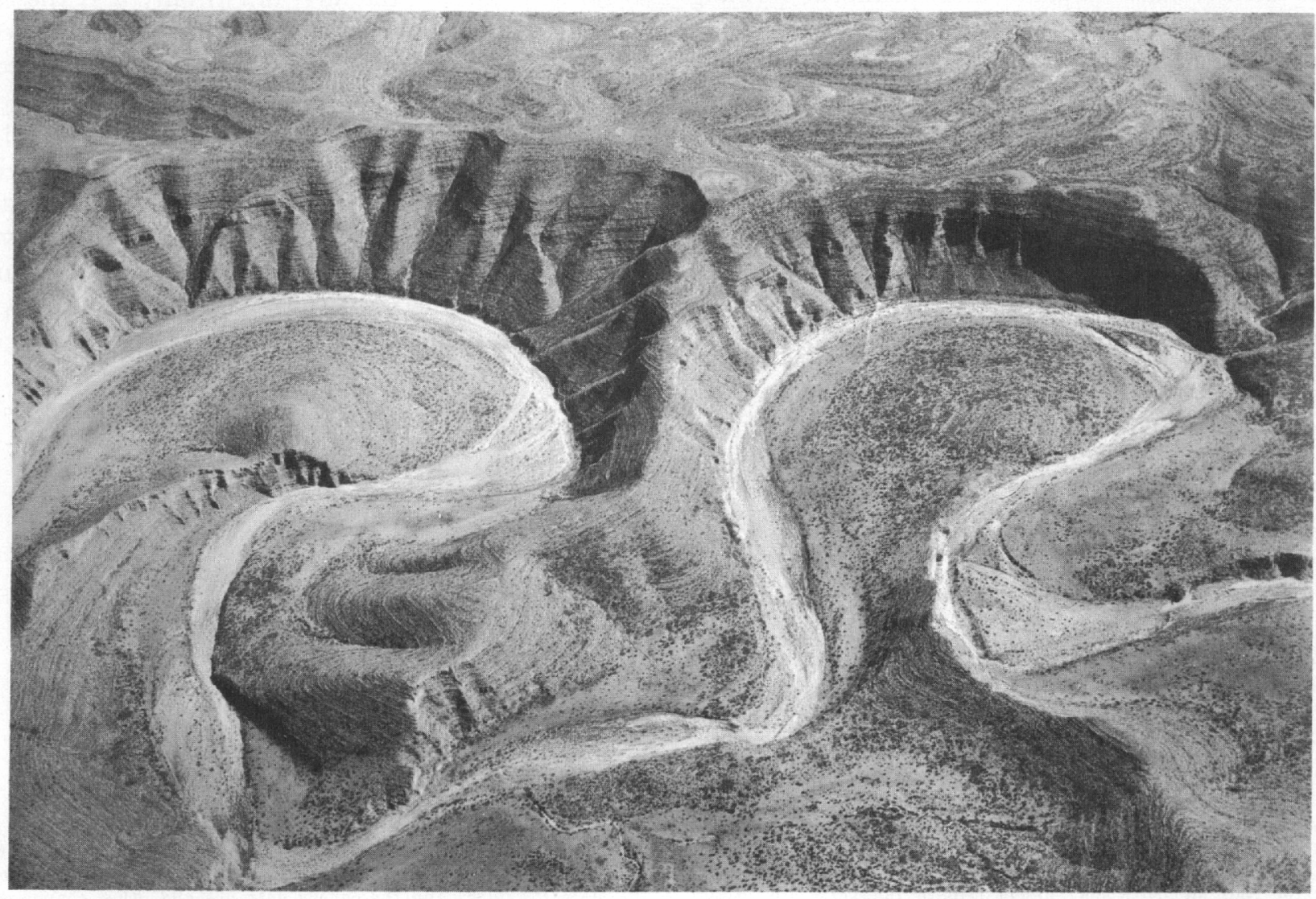

Figdre 26.-Incised meanders of Dark Canyon at Serpentine Bends. Undercut bank at top left ts 600 feet high. The lower twothirds of the cliff is held up by dolomite of the Seven Rivers Formation; the Yates Formation is in elope at top. 
near the heads of many of the smaller drainage courses flowing off the Reef Escarpment, such as at Calamity Cove and Lefthook and Nuevo Canyons, are apparently controlled by the joint system parallel to the escarpment.

Except for Black River, which may follow the approximate course of an early Tertiary stream, most of the other drainage courses in the area are directly or indirectly controlled by the late Pliocene and early Pleistocene structure of the region. This is particularly evident in the Dog Canyon-Brokeoff Mountain area where most major drainage courses follow synclinal axes, grabens, faults, and joints, and the tributaries are resequent drainage courses normal to fault scarps. A major exception is an obsequent tributary of Upper Dog Canyon which has cut through El Paso Ridge at El Paso Gap to capture the Shattuck Valley drainage.

In the Castile Formation in the southeastern part of the area, east-northeastward-draining stream courses, such as Hay Hollow and Cottonwood Draw, are apparently consequent streams following the regional dip.

The drainage courses between the Guadalupe Mountains and Black River, those draining into the Salt Flat, and some of those in the Seven Rivers Embayment are typical arid-climate bajada- and pediment-forming washes.

Nearly all the stream courses are dry except after heavy rains, and the only perennial streams are in stretches of certain drainage courses below large springs.

Except for about an 8-mile stretch beginning about 2 miles below the discharge of Rattlesnake Spring, Black River flows perennially from near Bottomless Lakes to its confluence with the Pecos River outside the mapped area. A 3-mile stretch of nearly constant spring-fed streamflow is present in Dark Canyon above X-Bar
Ranch headquarters. Very short stretches of perennial flow are found below springs in Juniper, Last Chance, and Sitting Bull Canyons.

\section{CAVES}

Cave openings, some of which are now blocked by talus, are numerous in the report area. Most of the caves are in the Capitan Limestone and carbonate rock of the Artesia Group between Dark Canyon and the Reef Escarpment, but a few small caves are in the San Andres Limestone in Last Chance Canyon and in the Rocky Arroyo drainage. At least one is in the large calcareous tufa deposit at Sitting Bull Falls. Seventeen cave openings are shown on the geologic map. These are probably most of the larger caves, but several other small caves are known (table 1).

By far the largest known cave in the area is the Carlsbad Cavern which underlies an area nearly 1 mile long by more than one-half mile wide (figs. 27,28 ; table 1 ). Except for New Cave and Cottonwood Cave, which has a corridor one-fourth of a mile long (Bretz, 1949, p. 456 ), most of the other caves in the area are no more than a few hundred feet in maximum dimension, and some are apparently no more than chimneys. However, so far as is known, the interiors of only 9 of the caves have been described, and only 4 have been mapped.

Carlsbad Cavern was first mapped and described by I (1925) and has since been discussed in many papers, such as those by Davis (1930, p. 572-578), Bretz (1942, 1949), T. M. Black (1954), Gale (in Hayes, 1957), Good (1957), and Moore (1960). New Cave, formerly Slaughter Canyon Cave, was also mentioned in several of those papers, but was described more fully by Burnet (1938). It was mapped (fig. 28) during fieldwork for the present project. Bretz (1949) has briefly des-

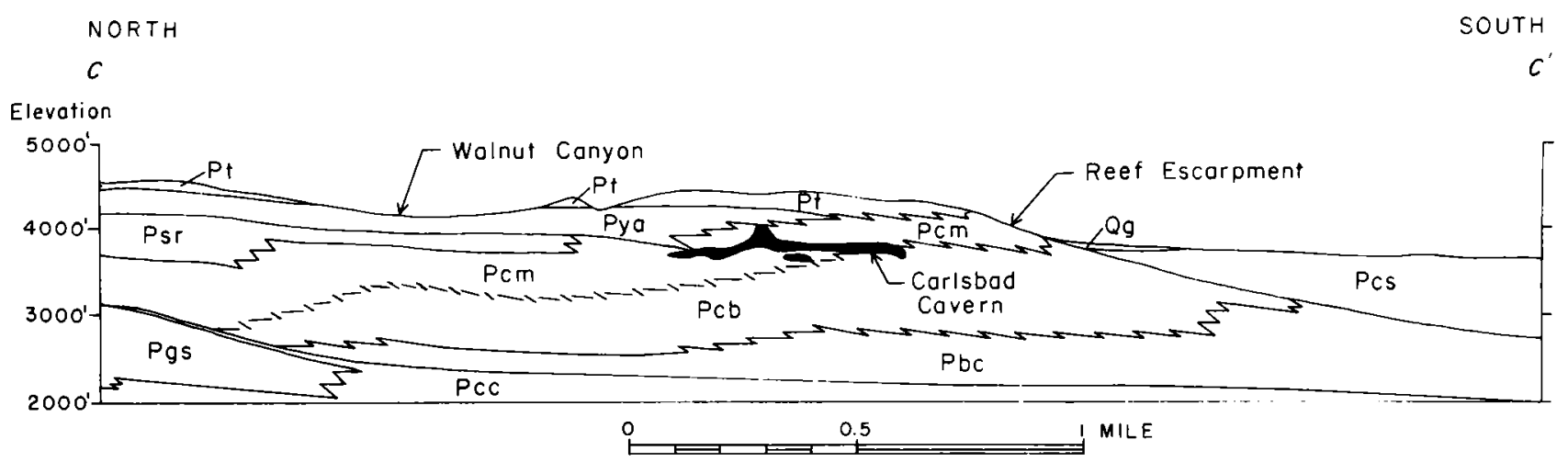

Figure 27.-Section $C-C^{\prime}$ through the Capitan Limestone and associated rocks showing position of Carlsbad Cavern (solid black area). (See pl. 1 for line of section.) Most of the cave is in the massive member of the Capitan Limestone (Pcm), but the south end of the Big Room is in the breccia 'member of the Capitan (Pcb); a basal sandstone tongue of the Yates Formation (Pya) is present in the New Mexico Room; higher beds of the Yates are present in the Main Corridor: and the cavern entrance and other chambers (not shown) are in the Tansill Formation (Pt). Other units in the cross section are the Seven Rivers Formation (Psr), Goat Seep Dolomite (Pgs), Cherry Canyon Formation (PCC), Bell Canyon Formation (Pbc), Castile Formation (Pcs), and gravel (Qg) of Quaternary age. 
cribed significant features of Black, Hidden, Cottonwood, and Mudgetts caves (table 1). George Moore mapped and described a small cave in Lechuguilla Canyon (fig. 28) known as Lechuguilla Cave, and Howard (1935, p. 63-65) described Burnet Cave (not shown on pl. 1) in Last Chance Canyon. Most of the other caves have been briefly described by Crisman (1960), and Goat Cave was briefly examined during the present in- vestigation. Table 1 shows comparative data on 11 of the caves in the area.

Because the origin and development of the caves have been discussed comprehensively in other papers, only a summary of the conclusions reached in those papers is presented here. For more complete descriptions of the caves and for more detailed analyses of their development, the reader is referred to the several reports cited herein.
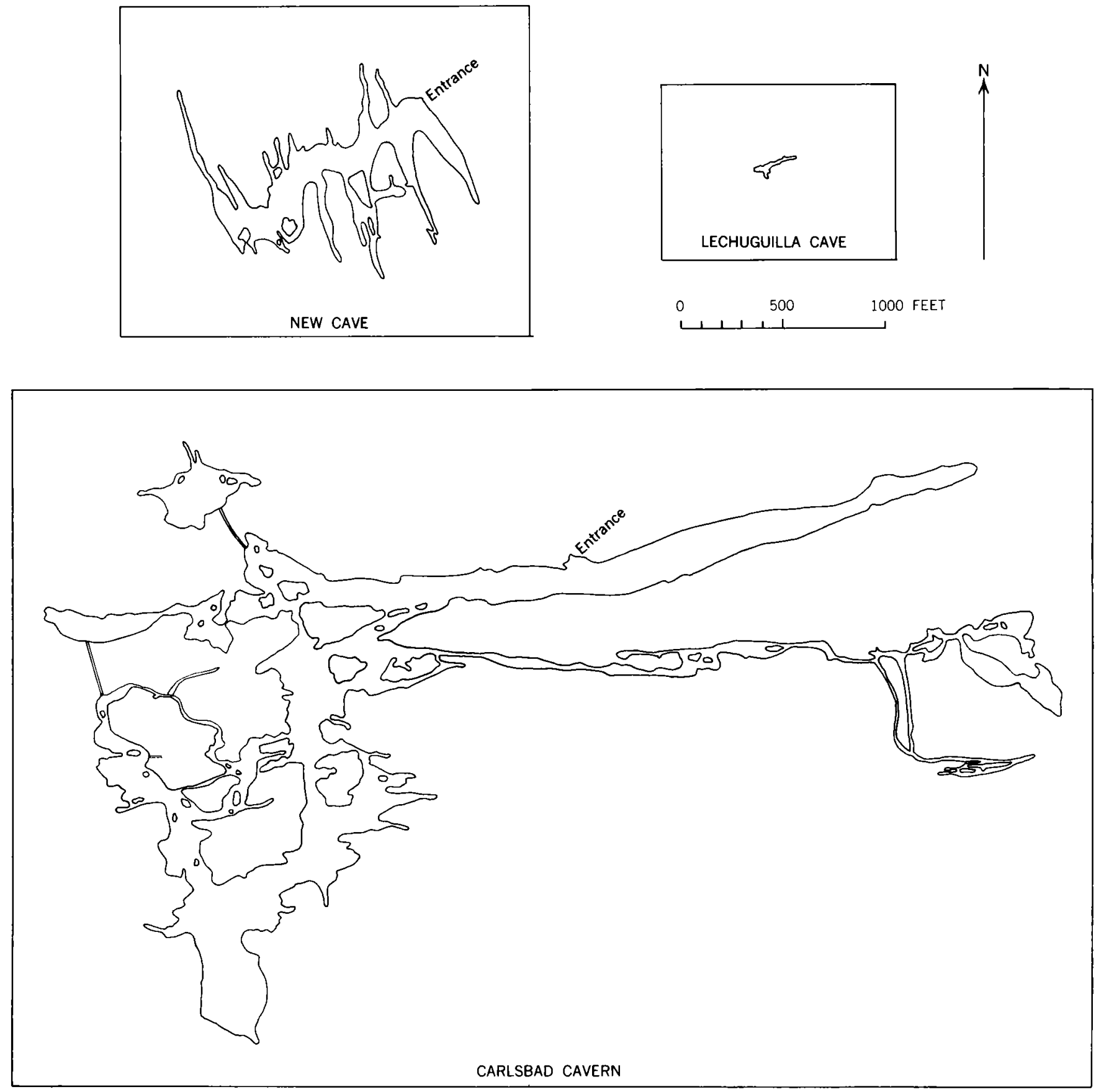

Figore 28.-Outline maps of three caves of the Guadalupe Mountains showing relative sizes and shapes of the joint-controlled passages. The map of Lechuguilla Cave is by George W. Moore, of the U.S. Geological Survey; the map of Carlsbad Cavern is based on the original map of Willis T. Lee with modifications and additions made by or for the U.S. National Park Service. 
Davis (1930, p. 578) suggested that Carlsbad Cavern formed in two cycles, including an early period of solution in the zone of ground-water saturation (phreatic zone) which caused the excavation of the cave, followed by a period during which the cave was partly filled with dripstone and flowstone in the vadose zone. This history of development was accepted in principle by Bretz (1949). Swinnerton (1932, p. 667) and Gardner (1935), however, maintained that most solution took place at the water table, and that as the water table was lowered as a result of regional uplift, lower levels were excavated while the higher levels began to be filled by dripstone and flowstone due to precipitation of calcium carbonate from vadose waters. T. H. Black $(1954$, p. 137), Gale (in Hayes, 1957), and Good (1957, p. 20) adopted the two-cycle theory of phreatic solution followed by vadose precipitation, but agreed with Swinnerton that the most active solution took place at, or just below, the water table. They thus attributed the several well-defined levels of Carlsbad Cavern to long periods of stability in the level of the water table.

Both Bretz (1949) and Gale (in Hayes, 1957) presented evidence to show that most of the solution of Carlsbad Cavern and probably of all the solution caves in the area took place before the development of the present erosion surface and that the solution began along joints. Most of the solution probably took place from early in the Tertiary Period until near the end of the Tertiary or later. Motts (1959) believes that some solution is still taking place in the lower levels of Carlsbad Cavern. The late Pliocene or early Pleistocene uplift of the Guadalupe Mountains caused a lowering of the water table, and the vadose cycle of carbonate precipitation began. Carlsbad Cavern and New Cave apparently were partly refilled by water several times after the initial formation of dripstone. This is indicated by solution of some of the dripstone formations in New Cave (Bretz, 1949, p. 456; Grale, in Hayes, 1957), by the same phenomenon in Carlsbad Cavern, and by the presence of " - a clinker-like deposit of calcium carbonate deposited [on preexisting dripstone formations to a uniform level] during an episode of re-flooding" (Black, T. H., 1954, p. 140). A thick depoisit of gypsum on the floor of the Big Room of Carlsbad Cavern indicates that waters heavily charged with calcium sulfate partly filled the cave after the end of the first phreatic cycle (Black, T. H., 1954, p. 140; Good, 1957, p. 19). This gypsum could have been derived from the Castile Formation before it was eroded to its present level or from somewhat more distant sulfate beds in the evaporite facies of the Artesia Group.

Although all the caves in the area are now relatively dry, in Carlsbad Cavern there is evidence that two or three vadose streams have occupied the cave (Bretz, 1949, p. 451-453; Black; T. H., 1954, p. 140-141; Gale, in Hayes, 1957). The bones of a Pleistocene ground sloth, Nothrotherium, have been found in streamdeposited silt in the lower levels of Carlsbad Cavern, thus dating the stream as no later than Pleistocene (Gale, in Hayes, 1957). These stream deposits are now covered by flowstone and large dripstone deposits.

Probably most dripstone and flowstone in the caves were deposited during wet-climate periods concurrent with the advance of the Pleistocene ice sheets farther north. That the climate in the region was much colder and probably much wetter during the latest glacial advance is shown by the occurrence of fossils of late Pleistocene arctic-alpine birds and mammals in Burnet Cave (Schultz and Howard, 1935).

Description of the varied and, in places, bizarre dripstone, flowstone, and rimstone formations of the caves, and of the unusual mineral occurrences in the caves is beyond the scope of this paper. The literature on cave deposits in general is extensive. T. H. Black (1954) and Gale (in Hayes, 1957) have described the secondary deposits of Carlsbad Cavern, and D. M. Black (1956) has described an unusual type of rimstone in New Cave which he called a "furled retaining wall." Good (1957) has described and discussed the relatively minor, but very interesting, noncarbonate deposits of Carlsbad Cavern, and Davies and Moore (1957) have described the occurrence there of the minerals endellite and hydromagnesite.

\section{GEOLOGIC HISTORY}

Very little is known about the Precambrian history of the Guadalupe Mountain region. Granitic and metamorphic rocks in the Precambrian in several deep wells suggest that the region was part of an ancient orogenic belt. By analogy with dated Precambrian rocks of similar lithology elsewhere in New Mexico and in western Texas (Jaffe and others, 1959) these rocks can probably be classified as less than one billion years old. There is no record of the latest Precambrian or most of Cambrian time in the area; however, the area was reduced to a nearly level plain on which Paleozoic rocks were later deposited.

During most of the Paleozoic Era, until near the end of the Mississippian Period, the present report area was part of a broad low-lying stable region that was intermittently covered by shallow seas. The marine invasions resulted in the deposition of about 2,500 feet of predominantly carbonate rock from the base of the Bliss Sandstone to the top of the Helms shale.

Early in Pennsylvanian time, after a half billion years of stability, submarine tectonism began in the 
TABLE 1.-Descriptive data on some caves in the Guadalupe Mountains

\begin{tabular}{|c|c|c|c|c|c|c|c|c|}
\hline \multirow{2}{*}{ Name of cave } & \multicolumn{3}{|c|}{ Location of entrance } & \multirow{2}{*}{$\begin{array}{l}\text { Formation in which } \\
\text { formed }\end{array}$} & \multirow{2}{*}{$\begin{array}{l}\text { Principal jolnt } \\
\text { directions }\end{array}$} & \multirow{2}{*}{ Brief description } & \multirow{2}{*}{$\begin{array}{l}\text { Maximum } \\
\text { length (feet) }\end{array}$} & \multirow{2}{*}{ 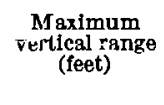 } \\
\hline & Sec. & T.(S.) & R.(E.) & & & & & \\
\hline Black & 29 & 25 & 22 & Seven Rivers & N. $10^{\circ}$ W. ${ }^{1}$ & $\begin{array}{l}\text { Three closely spaced } \\
\text { parallel passages with } \\
\text { a short connecting } \\
\text { cross chamber. }\end{array}$ & Unknown & Unknown \\
\hline Burnet ${ }^{2}$ & 35 & 22 & 21 & $\begin{array}{l}\text { San Andres } \\
\text { Limestone. }\end{array}$ & N. $30^{\circ} \mathrm{W} \cdot{ }^{3} \ldots$ & $\begin{array}{l}\text { One joint-controlled } \\
\text { passage. }{ }^{3}\end{array}$ & $55 \pm{ }^{3}-$. & $25 \pm^{3}$ \\
\hline Carlsbad _. & 31 & 24 & 25 & $\begin{array}{l}\text { Entrance in } \\
\text { Tansill; most of } \\
\text { cave in Capitan } \\
\text { Limestone } \\
\text { (fig. 27). }\end{array}$ & $\begin{array}{l}\text { Approx N. } 75^{\circ} \\
\text { E. and N. } \\
15^{\circ} \mathrm{W} .\end{array}$ & $\begin{array}{l}\text { Very large joint- } \\
\text { controlled chambers, } \\
\text { corridors, and narrow } \\
\text { passages on several } \\
\text { levels. }\end{array}$ & 4,600 & 1,025 \\
\hline Chimney & 2 & 25 & 24 & $\begin{array}{l}\text { Capitan Lime- } \\
\text { stone. }\end{array}$ & Unknown.- & Vertical slot. & Negligible_. & $150(?)^{1}$ \\
\hline Cottonwood. & 6 & 26 & 22 & Seven Rivers & N. $15^{\circ} \mathrm{W}^{1}$ & Simple linear cha ${ }_{1.2 b e r}{ }^{1}$ - - & $1,300 \pm \ldots$ & $225^{1}$ \\
\hline Goat .... & 11 & 25 & 23 & $\begin{array}{l}\text { Capitan Lime- } \\
\text { stone. }\end{array}$ & $\begin{array}{l}\text { Approx N. } 35^{\circ} \\
\text { W. }\end{array}$ & Broad elongate chamber-- & $500+-$ & $100+$ \\
\hline Hidden & 29 & 25 & 22 & Seven Rivers & $\begin{array}{l}\text { N. } 10^{\circ} \mathrm{W} ., \mathrm{N} . \\
30^{\circ} \mathrm{W} ., \mathrm{N} . \\
80^{\circ} \mathrm{E.i}\end{array}$ & $\begin{array}{l}\text { Six or seven straight } \\
\text { narrow joint-controlled } \\
\text { passages. }{ }^{1}\end{array}$ & Unknown & Unknown \\
\hline Lechuguilla_ & 28 & 24 & 24 & Yates & $\begin{array}{l}\text { N. } 60^{\circ} \mathrm{E} ., \mathrm{N} . \\
30^{\circ} \mathrm{W} .\end{array}$ & $\begin{array}{l}\text { Chimney opening into a } \\
\text { linear chamber with } \\
\text { short narrow side }\end{array}$ & 215 & 100 \\
\hline Mudgetts & 21 & 24 & 24 & Seven Rivers_. & N. $75^{\circ}$ E. ${ }^{-}$ & One straight horizontal & $750+1 \ldots$ & Slight \\
\hline New & 23 & 25 & 23 & $\begin{array}{l}\text { Capitan Lime- } \\
\text { stone. }\end{array}$ & $\begin{array}{l}\text { N. } 20^{\circ} \mathrm{W} ., \mathrm{N} . \\
60^{\circ} \mathrm{E} .\end{array}$ & $\begin{array}{l}\text { chamber. }^{1} \\
\text { Large sinuous chamber } \\
\text { with several long sub- } \\
\text { parallel side passages, } \\
\text { some of which are } \\
\text { interconnected. }\end{array}$ & $1,150 \ldots$ & 250 \\
\hline Sitting Bull_ & 3 & 24 & 22 & $\begin{array}{l}\text { Tufa of Quater- } \\
\text { nary age. }\end{array}$ & None & $\begin{array}{l}\text { Formed by the irregular } \\
\text { growth of calcareous } \\
\text { tufa. }\end{array}$ & $100 \pm$ & Slight \\
\hline
\end{tabular}

1 Bretz (1949).

2 Not shown on plate 1.

3 Howard (1935).

report area. Intermittently throughout Pennsylvanian time the southwestern part of the area was elevated relative to the northeastern part along the northwestwardtrending Huapache thrust zone. The uplifted area is probably a southeastern branch or extension of the Pedernal uplift of central New Mexico (fig. 3). Within the report area, uplift was apparently greatest in the north. Most of the uplift probably took place beneath seas that had advanced over the area early in Pennsylvanian time and that had fluctuated in depth. Periodically, submarine or subaerial erosion took place on the higher areas, and reworked sediments were dumped in the lower areas adjacent to the fault zone. Concurrent with movement along the Huapache fault zone, local bulging of the sea bottom in the deeper part of the sea to the northeast produced variable thicknesses of Pennsylvanian sediments. Toward the close of Pennsylvanian time or very early in Permian time, tectonic activity virtually ceased, and mixed continental and marine sediments were deposited in the lower areas nearly obliterating the irregular sea-bottom topography caused by the tectonism. Either the area southwest of the Huapache thrust zone remained slightly higher than
1 Moran's (1955, p. 258) belief that sandstone beds foind in Carlsbad Cavern may be shelfward tongues of the Delaware Mountain Group is not substantiated basal part of the Yates Formation as originally suggested by T. H. Black (1954 p. 136).

the area to the northeast, or there was minor renewed movement along the thrust zone early in Permian time, resulting in a somewhat greater accumulation of sediments of Wolfcamp and early Leonard age northeast of the old uplifted area than on the uplifted area.

Concurrent with beginning of Early Pennsylvanian tectonism, the Delaware basin may have begun to subside, but it was during Wolfcamp time that the basin first began to assume a deffnite shape. The northwest margin of the basin still was not sharply defined, however, and it is reflected today by the broad facies change from dolomite of the Hueco Limestone of the Northwest-shelf area to limestone and shale in the basin.

The Delaware basin subsided fartehr in Leonard time, and the northwest margin of the basin became more definite in form, possibly because of incipient movement early in the epoch along the line of the Bone Spring monocline. Along this hinge line, great submarine-bank deposits of the Victorio Peak Limestone were laid down. These deposits apparently formed a barrier to free circulation; black shale and fetid limestone of the Bone Spring Limestone were deposited in the basin simultaneously with deposition of the dolo- 
mite, ${ }^{4}$ siltstone, and evaporites of the Yeso Formation in the shelf area.

At about the end of Leonard time pronounced differential movement occurred along the basin margin, and the Bone Spring arch was elevated, forming a barrier, 15 to 20 miles wide, between the Delaware basin and the Northwest-shelf area. A marked change in sedimentation ensued. Black shale and limestone deposition in the basin was followed by deposition of sandstone and siltstone of the Brushy Canyon Formation which lapped onto the eroded edge of the Bone Spring monocline. Meanwhile, virtually clastic-free carbonate of the lower part of the San Andres Limestone was deposited in the shelf area northwest of the Bone Spring arch. By the end of Brushy Canyon time, relief on both sides of the Bone Spring arch was masked by onlapping sediments. Sand and silt of the lower part of the Cherry Canyon Formation were then deposited in the basin and over the southeastern part of the arch, and these sediments merged northwestward with the simultaneously deposited carbonates in the upper part of the San Andres Limestone. The source of the sand and silt of the Brushy Canyon Formation and lower part of the Cherry Canyon Formation is unknown. Contemporaneous deposition of carbonate rock to the northwest seems to preclude the possibility of a source in that direction as suggested by King (1942, p. 31). Newell and others (1953, p. 94) and Hull (1957, p. 297) have presented evidence that turbidity currents played a role in the deposition of sediments of the Delaware Mountain Group. Perhaps sediments of the Brushy Canyon and the lower part of the Cherry Canyon were carried into the basin by turbidity currents from an unknown source to the south.

Near the end of San Andres time or early in Cherry Canyon time, local uplift along the northwest edge of the Bone Spring arch resulted in the erosion of the upper part of the San Andres and Cherry Canyon transition zone before Grayburg deposition. At the same time the Bone Spring monocline may have been slightly rejuvenated, thus emphasizing the hinge line of the basin margin. Conditions were established that led to the accumulation of the lime-bank deposits of the lower part of the Goat Seep Dolomite directly on the Bone Spring monocline. In turn, these deposits formed a foundation for the growth of a barrier reef, represented by the upper part of the Goat Seep Dolomite. Near the beginning of Goat Seep deposition, quartzose clastic sediments began to be carried into the area from the northwest for the first time since deposition of the

\footnotetext{
According to Adams and Rhodes (1960), these shelf dolomites of Permian age were originally deposited as calclum carbonate and then altered to dolomite by highly magnesian lagoonal waters refluxing to the basin.
}

Yeso Formation, and they are preserved as sandstone and siltstone beds in the Grayburg and Queen Formations. The source of these clastics may have been the distant Uncompahgre highland (fig. 3). Highlands nearer to the report area, such as the Pedernal uplift, apparently had been buried by earlier Permian sediments. Some of the clastics apparently washed over and through gaps in the barrier reef at the basin margin, but, in general, the bank and reef of Goat Seep age probably formed a fairly effective barrier to passage of clastics into the basin. The silt and sand of the upper part of the Cherry Canyon Formation that were deposited at the same time in the basin were probably still being derived, in large part, from source areas to the south. The great lime bank and reef barrier at the basin margin also restricted the flow of water from the basin to the shelf. This restriction of circulation, coupled with evaporation, led to the precipitation of calcium sulfate on the shallow lagoon floor about 15 to 25 miles shelfward; at the same time limy mud and sand were deposited closer to the reef zone. Just before the end of Cherry Canyon time, a slight lowering of sea level or a slight raising of the basin margin apparently caused a brief cessation of reef growth, and the highest beds of the Cherry Canyon and Queen Formations lapped onto both sides of the dead reef.

Shortly thereafter, at the beginning of Bell Canyon time, conditions again favored reef growth, and the reef limestone that makes up the massive member of the Capitan Limestone began to grow upward and basinward from the top of the Goat Seep Dolomite. Details of the formation of the Capitan Limestone and its shelf and basin equivalents have been described by many workers (Lloyd, 1929; Adams and Frenzel, 1950; Newell and others, 1953), ${ }^{5}$ and are summarized here with a few additional ideas.

During part of Seven Rivers time and during Tansill time, the reef grew upward more than basinward, but in most of Seven Rivers time and in Yates time, it grew basinward at a much faster rate than upward. This obliquely upward growth of the reef indicated to Newell and others (1953, p. 106-107) that subsidence of the basin margin was slow relative to the rate of reef growth resulting in the reef (massive member) growing out over its own talus (breccia member). The relatively rapid outward growth, which would tend to leave the most seaward part of the reef unsupported, may also explain the greater abundance of reef talus than of reef rock. It is also possible that the frame-building algae, sponges, and bryozoans of the Capitan did not form as rigid a framework as is found in many modern

\footnotetext{
- Other origins for the Capitan Limestone have been postulated by Cave (1954) and Moore (1959).
} 
reefs; this comparative lack of rigidity might cause the reef to break up into talus more readily.

The probable northwestern source area of quartzose clastic sediments diminished greatly in importance at the end of Queen time, and during Seven Rivers time contributed very little sediment to the shelf area. At the same time, the probable southern source of basin sediments may have decreased its output as reflected by a relatively small amount of clastic rock between the base of the Bell Canyon Formation and the Rader Limestone Member. Carbonate deposition, however, continued in the shelf area near the reef zone and almost kept pace with reef growth. In the shallow lagoonal waters adjacent to the reef, bioclastic carbonate debris, pisolites, and oolites accumulated. Farther from the reef, carbonate mud was the chief sediment. Several miles back, evaporation exceeded replenishment of water from the basin, and the evaporite deposits of the Artesia Group were deposited by precipitation.

An influx of quartzose sediment from the northwest occurred in Yates time. Much of this sediment was trapped behind the reef and remains as the sandstone and siltstone beds of the Yates Formation, but much also apparently washed over and through gaps in the reef. In the process of washing over the reef, natural cavities in the reef rock were filled by clastic sediments, and much of the sediment also apparently got through the reef to the basin to mix with clastic sediments possibly still being contributed from the south. This is suggested by the large proportion of clastic rock in the part of the Bell Canyon Formation equivalent to the Yates between the Rader and Lamar Limestone Members. In addition to pockets and stringers of sandstone in the reef, evidence that much of this quartzose sediment washed over and past the reef is indicated by the close similarity of sandstone of the Yates and Bell Canyon Formations, and by the pinchout of sandstone beds of the Bell Canyon between foreset beds of limestone in the breccia member of the Capitan Limestone. During intervals of Yates time when quartz sand and silt were not being brought into the lagoon in volume, limestone and evaporite deposition took place much as it had during Seven Rivers time. Conditions during Tansill time repeated those of Seven Rivers time, and very little quartzose sediment was deposited.

As the reef of Capitan age grew, deposition in the basin proceeded at a slower rate than on the shelf and did not keep up with sinking of the basin. Consequently, the sea became progressively deeper in the basin throughout most of Bell Canyon time. Newell and others (1953, p. 69-77) have demonstrated that large submarine slides occurred in partially consolidated Bell Canyon sediments on the basinward slope away from the reef. By the end of Capitan time the sea bottom in the Delaware basin is estimated to have been about 1,500 feet lower than the lagoon floor adjacent to the reef on the north west.

Near the close of Capitan time, access of water to and from the open ocean became restricted, the seas of the shelf dried up, and the water of the Delaware basin became more saline, causing the end of reef growth. The few feet of nonfossiliferous limestone at the base of the Castile Formation probably resulted from the initial evaporation of the restricted water. Udden (1924) interpreted each pair of anhydrite and limestone laminae in the lower part of the Castile as annual layers resulting from seasonal variations in salinity. The warming of surface water in summer would result in the loss of carbon dioxide and the consequent decrease in solubility of calcium carbonate. Thus, the limestone laminae, which are high in organic content, are thought to represent warm-season deposition; whereas the intervening calcium sulfate laminae were deposited in the colder seasons. R. H. King (1947, p. 470) suggested that "the water within the basin consisted of a body of brine lying below average wave base and a less dense surface layer lying above average wave base" and that the barrier which closed off free circulation between the Delaware basin and the open sea to the south either had a top which "lay partly below wave base or the barrier was permeable." The relatively fresh surface waters of the basin were continually replenished from the open sea while the denser brines below drained out to sen over or through the barrier. Scruton (1953, p. 2502, 2510) accepted R. H. King's mechanism in principle, but suggested that the barrier to brine escape may have been in part dynamic; that is, outward flow of heavy brines may have been retarded by "pressures due to hydrostatic head and density distribution, friction between currents flowing in opposite directions, and friction between the deep current and the channel bottom." R. H. King (1947) believed that the few beds of halite in the Castile were deposited at times when the outflow of heavy brines was retarded or stopped. Scruton (1953) thought that variations in precipitation, temperature, sea level, and wind stress could also have contributed to vertical changes in sequence of evaporite beds.

By the close of Castile time, the Delaware basin was nearly filled with evaporite sediments, saline waters spread over the shelf areas for a unknown distance, and extensive salt deposition began resulting in the predominantly halite Salado Formation. That the replenishing waters of the open sea still apparently came from the south is suggested by greater amounts of the least soluble salts, such a calcium carbonate and cal- 
cium sulfate, far to the south in Texas; whereas the extremely soluble salts, such as sylvite and carnallite, are much more abundant in the northern part of the Salado Formation in New Mexico. Periodically during Salado time, clastic material swept far into the saline sea from the north and northeast leaving widespread but very thin beds of clay, silt, and sand. Toward the close of Salado time the influx of clastic material increased. Rustler time is marked by a great increase in clastic deposition and a concurrent freshening of the waters as reflected in a marked decrease in the relative abundance of halite and an increase in the proportion of carbonate rock. Broad epeirogenic uplift at the end of Permian time caused the seas to retreat, leaving the entire region above sea level.

Triassic or Jurassic rocks are not present in the report area, but the distribution of these and younger rocks elsewhere in New Mexico, Texas, and Mexico indicates that the area was above sea level throughout the Triassic and Jurassic Periods and into the Cretaceous Period. The area may have received flood-plain deposits in Late Triassic time (McKee and others, 1959, pl. 9), but, if so, they were stripped off and shed northward or southward during the Jurassic.

Late in Early Cretaceous time, shallow seas once again advanced over the area from the south but early in Late Cretaceous time probably retreated for the last time. Fossiliferous limestone and coarse sandstone and conglomerate were left behind to record this incursion of the sea. There is no record of most of Late Cretaceous time in the area. Probably the area was slightly above sea level.

Probably late in the Cretaceous Period or very early in the Tertiary Period the entire region was elevated by broad epeirogenic uplift and was tilted slightly to the northeast, and the report area apparently was subjected to mild tectonism. The three small igneous dikes in the area may have been intruded during or following these events. The tectonism produced the Walnut Canyon syncline, Guadalupe Ridge anticline, and related features. The stage was set for the establishment of the ancestral northeast-flowing drainage system. Black River, Walnut Creek (p. 47), Dark and Last Chance Canyons, and Rocky Arroyo probably originated at this time, and the caves in the limestones of Permian age began to form from phreatic solution.

During the Pliocene Epoch, the continental Ogallala Formation was deposited east of the present Pecos River, but it is not known whether or not any part of the present report area was once overlain by sedimentary rocks of the Ogallala. Thin remnants of siliceous conglomerate on top of the Guadalupe Mountains are interpreted in this report to be of Cretaceous age, and if the Ogallala was ever present, it has been removed by erosion.

Most of the faulting and main uplift of the Guadalupe Mountains probably occurred late in the Pliocene and early in the Pleistocene. The present drainage system and landforms, the Quaternary piedmont and alluvial deposits, the calcareous tufa accumulations, and most of the cave decorations have formed since the mountain uplift and are still being modified. Rates of erosion, deposition, and carbonate precipitation, both on the surface and in the caves, have fluctuated considerably with the climatic cycles, which, in turn, probably were controlled by the advances and retreats of continental glaciation to the north.

\section{ECONOMIC GEOLOGY}

\section{OIL AND GAS}

\section{PREVIOUS EXPLORATION}

Up to June $30,1961,81$ holes had been drilled in search of oil and gas within the report area; all but 17 of these holes are in the Delaware basin (table 2). Eight of the Delaware basin wells yielded oil, and four yielded gas of commercial value. Four of the oil wells were still producing early in 1960 .

All the oil wells are in the Black River field and produce $42^{\circ}$ gravity API oil (Stipp and others, 1956, p. 73 ) from fine-grained sandstone and siltstone just beneath the Lamar Limestone Member of the Bell Canyon Formation. This field is apparently on a small anticlinal nose or structural terrace. Production has never exceeded a few barrels per day per well.

The first gas well was the Union Oil Co. of Califormia Crawford 1-26 (sec. 26, T. 24 S., R. 26 E.), about 2 miles south of the Black River field. This well had an initial production capacity of 62,000 Mcf (thousand cubic feet) of natural gas per day from a depth of 11,060 to 11,074 feet in Lower Pennsylvanian rocks. The other gas wells are the Gulf Oil Corp. Estill 1-AD (sec. 29, T. 24 S., R 26 E.), the Union Oil Co. of California Crawford 2-27 (sec 27, T. 24 S., R. 26 E.), and the Superior Oil Co. Federal 1-134 (sec. 12, T. 26 S., R. 24 E.). These wells, which also produce from Pennsylvanian rocks, had initial production capacities of $46,000,7,200$, and 347 Mef per day, respectively.

Of the remaining 52 test wells which have been drilled in the Dela ware-basin part of the report area, 47 were drilled no deeper than a few feet below the Lamar Limestone Member of the Bell Canyon Formation, and 3 were apparently drilled into the underlying Cherry Canyon Formation. Thus, only 6 wells in this 255square-mile area have penetrated pre-Permian rocks, 
and only 9 have been drilled deeper than the shallowest potential producing zone.

In the shelf area outside the Delaware basin, 17 test wells have been drilled in about 730 square miles of area. All of them were dry holes. Three of the holes were drilled to Precambrian rocks, and eight were drilled into pre-Devonian rocks. The greater concentration of exploratory wells is in the Delaware basin; however, the average depth of the wells in the shelf area is about 4,000 feet greater than the average for wells drilled in the basin where the sedimentary rocks are thicker.

TABLE 2.-Oil and gas test wells drilled in report area before June 30,1961

[Abd., abandoned, dry hole; OW, oil well; AOW, abandoned oil well; $G W$, gas well]

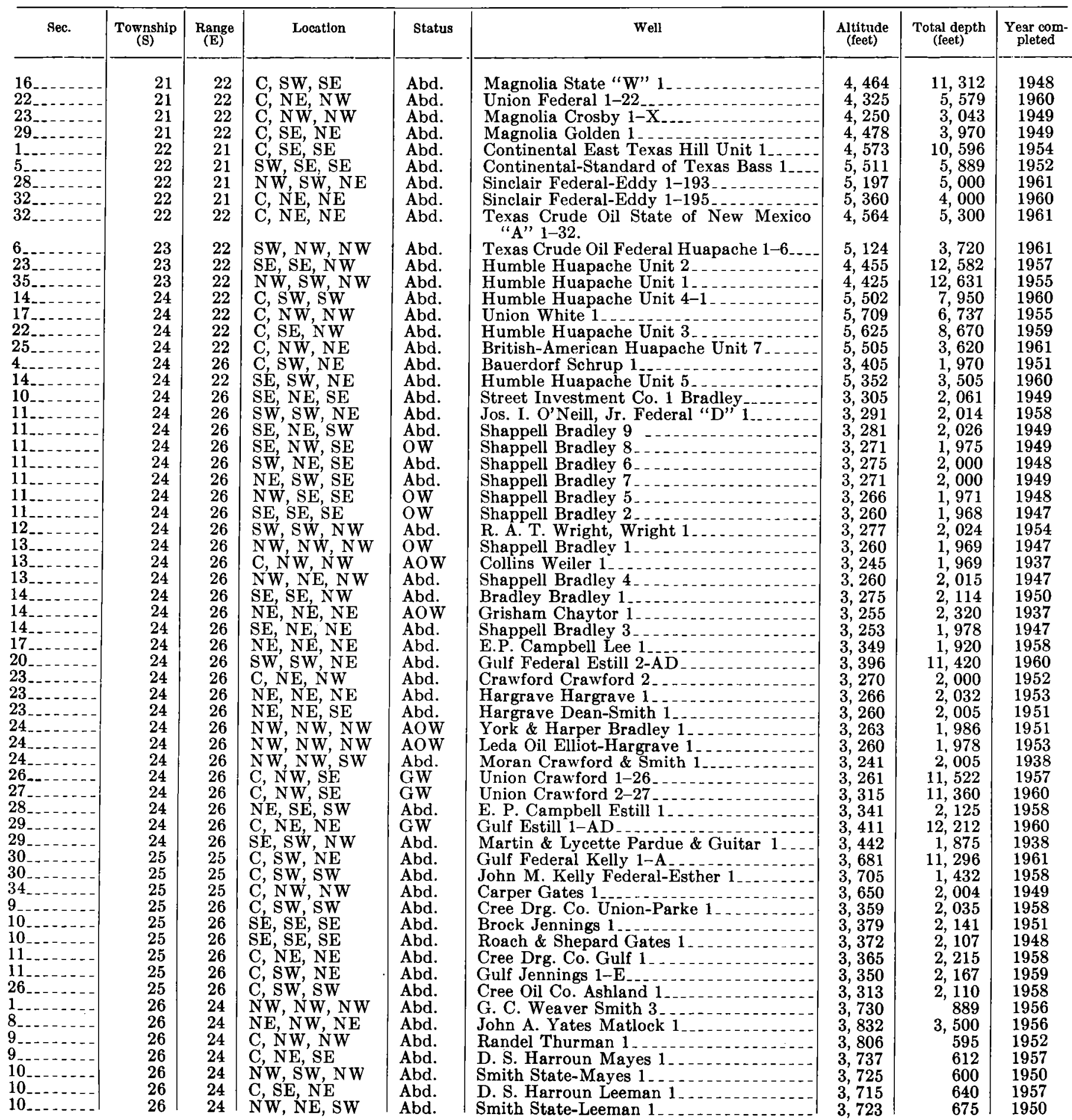


TABLE 2.-Oil and gas test wells drilled in report area before June 30,1961 -Continued

\begin{tabular}{|c|c|c|c|c|c|c|c|c|}
\hline Ser. & $\underset{\text { (S) }}{\text { Township }}$ & $\underset{(\mathrm{E})}{\text { Range }}$ & Location & Status & Well & $\underset{\text { (feet) }}{\text { Altitude }}$ & $\begin{array}{c}\text { Total depth } \\
\text { (feet) }\end{array}$ & $\begin{array}{l}\text { Year com- } \\
\text { pleted }\end{array}$ \\
\hline 12 & 26 & 24 & $\mathrm{C}, \mathrm{SE}, \mathrm{NE}$ & GW & Superior Federal 1-134 & 3,878 & 10,237 & 1960 \\
\hline 1 & 26 & 24 & $\mathbf{N}, \mathbf{S W}, \mathbf{N W}$ & Abd. & G. C. Weaver Smith 1 . & 3,870 & $\begin{array}{r}10,201 \\
2,513\end{array}$ & 1955 \\
\hline & 26 & 24 & $\mathrm{C}, \mathrm{NW}, \mathrm{SE}$ & Abd. & D. S. Harroun Leeman 2 & 3,715 & 618 & 1958 \\
\hline & 26 & 24 & NW, NW, NW & Abd. & G. C. Weaver Smith 2 & 3,765 & 707 & 1955 \\
\hline 22 & 26 & 24 & $\mathrm{NW}, \mathrm{NW}, \mathrm{NE}$ & Abd. & G. C. Weaver Smith 4 - & 3,813 & 788 & 1956 \\
\hline & 26 & 24 & $\mathrm{NE}, \mathrm{NW}, \mathrm{NE}$ & Abd. & G. C. Weaver Smith 5 & 3,830 & 788 & 1956 \\
\hline & 26 & 25 & $\mathrm{SE}, \mathrm{SE}, \mathrm{NE}$ & Abd. & W. E. Doolin Milner 1 & 3,490 & 1,870 & 1957 \\
\hline & 26 & 25 & $\mathbf{S W}, \mathbf{S W}, \mathbf{S W}$ & Abd. & W. E. Doolin Erickson 1 & 3,686 & 1,820 & 1957 \\
\hline 26. & 26 & 25 & $\mathrm{NW}, \mathrm{NW}, \mathrm{NW}$ & Abd. & W. E. Doolin McKean 1 & 3,602 & 1,488 & 1957 \\
\hline & 26 & 26 & C, SE, SE & Abd. & John M. Kelly State "EP' & 3,287 & 2,057 & 1958 \\
\hline & 26 & 26 & NE, NE, SE & Abd. & W. E. Doolin Hodges 1 & 3,482 & $\overrightarrow{1}, 935$ & 1957 \\
\hline & 26 & 26 & C, SE, SW & Abd. & McBride Randel 1 & 3,541 & 2,702 & 1951 \\
\hline 17. & 26 & 26 & SE, SE, NW & Abd. & W. E. Doolin Randel $1-X$ & 3,472 & 1,832 & 1957 \\
\hline & 26 & 26 & SW, SW, SW & Abd. & W. E. Doolin Price 1 & 3,454 & 1,620 & 1957 \\
\hline
\end{tabular}

\section{FUTURE POSSIBITITIDS}

On the basis of results of previous drilling in areas to the east, northeast, and southeast, it appears that the best potential production zones in the Delaware basin are in the Bone Spring Limestone, Pennsylvanian rocks, limestone of possible Devonian age above the Fusselman Dolomite, and the El Paso Formation. The best potential structural conditions for accumulation of oil and gas might be found on the southeast projection of the trend of the Huapache monocline (pl. 1) where buried structure similar to the Huapache thrust zone might be present (p. 42). To date (1961), most of the Delaware-basin oil fields produce from near the top of the Bell Canyon Formation. More such fields may be found.

Exploration for oil and gas in the Guadalupe Mountains area has been disappointing. The greatest potential probably lies in the Lower Permian and Pennsylvanian rocks of the Seven Rivers Embayment, adjacent to the Huapache monocline (pl. 1); but as in the Delaware basin, pre-Pennsylvanian rocks offer possibilities throughout the shelf area.

\section{GYPSUM}

Vast deposits of relatively pure fine-grained gypsum in the Castile Formation underlie an area of more than 100 square miles in the southeastern part of the area. These deposits are at or near the surface and are as much as several hundred feet thick. Probably enough gypsum is present to supply the total world demand for centuries, and much of it is of sufficient purity for industrial purposes. However, the price of gypsum has been so low in relation to transportation costs that up to June 1960 no important attempt had been made to exploit the deposits.
Although most of the vast quantities of gypsum in the area are fine grained, some selenite of fair quality is present; but none of optical quality has yet been found. The best potential area for prospecting is in the Yeso Hills, where selenite occurs along the east-northeasttrending linear features indicated on the geologic map (pl. 1). At least one prospect hole has been dug in this area and selenite is abundant around it.

\section{BUILDING STONE}

No high-quality building stone is present in the area, but flaggy dolomite from the Tansill Formation has found local use, notably for the construction of buildings at Carlsbad Caverns for the U.S. National Park Service. Other rocks have been used by local residents for houses and stone walls.

\section{GRAVEL}

Limestone gravel deposits have been quarried at several places along U.S. Highway 62 for use as road metal. In most places the gravel requires screening, but the supply meets the limited demand.

\section{SODIUM SULFATE}

Concentrated brines rich in sodium and magnesium sulfate are present locally in gypsum immediately overlying unaltered anhydrite in the Castile Formation. In 1906 brine was discovered at a depth of 160 feet in a well drilled for water in sec. 30, T. 25 S., R. 27 E., about 1 mile east of the mapped area. In 1934 brine from a depth of 170 feet from another water test hole drilled in sec. 29 , T. 24 S., R. 26 E., was analyzed and found to contain abundant sodium sulfate (Lang, 1941, p. 152). Since then, about 65 test wells have been drilled in the mapped area in search for brine in the Castile Forma- 
tion. Of these test holes, in at least 32 brine was found at depths ranging from 67 to 165 feet. These wells are in sec. 36 , T. 25 S., R. 25 E.; secs. $14,16,22,23,25,26,27$, $30,32,35$, and 36, T. 25 S., R. 26 E.; and secs. 2 and 3 , T. 26 S., R. 26 E. Until 1957, brine was produced commercially by the Ozark-Mahoning Co. from a well near Paxton water well in Cottonwood Draw. The brine was transported for the purpose of separation of the sodium sulfate more than 100 miles by truck to Monahans, Tex. The operation was stopped for an indefinite period in 1957 because of pumping and transportation costs (Robert S. Fulton, written communication, August 1958). Production figures are not known.

Chemical analyses of brines from four wells, as reprinted from Lang (1941, p. 154), are listed in table 3.

TABLE 3.-Chemical analyses of brines from four wells Eddy County, N. Mex.

[Laboratory of the U.S. Geological Survey, Midwest, Wyo. 1, Forehand 2, sec. 25, . sec. 26 , T. 25 S., R. 26 E.; 4, D. P. Welch 2 , sec. 8 , T. 26 S., R. 27 E.]

\begin{tabular}{|c|c|c|c|c|}
\hline & \multicolumn{4}{|c|}{ Grams per liter } \\
\hline & 1 & 2 & 3 & 4 \\
\hline 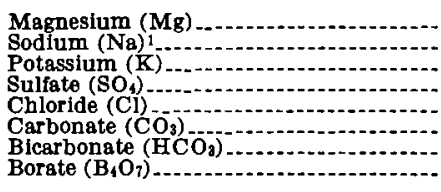 & $\begin{array}{r}41.3 \\
43.1 \\
16.6 \\
236.7 \\
24.8 \\
.3 \\
1.0 \\
2.9 \\
\end{array}$ & $\begin{array}{r}46.2 \\
59.5 \\
1.8 \\
245.5 \\
39.7 \\
-4.5 \\
10.3 \\
\end{array}$ & $\begin{array}{r}53.5 \\
61.1 \\
4.6 \\
304.5 \\
24.4 \\
1.7 \\
1.8 \\
7.4 \\
\end{array}$ & $\begin{array}{r}39.6 \\
32.3 \\
1.2 \\
187.2 \\
25.4 \\
1.7 \\
4.0\end{array}$ \\
\hline - & 366.7 & 407.5 & 468.0 & 291.4 \\
\hline Bpecific gravity & 1. 290 & 1.320 & 1.363 & 1. 236 \\
\hline
\end{tabular}

I Sodium calculated; other constltuents determined.

Lang (1941, p. 156-157) stated that meteoric waters percolating through porous weathered gypsum in the vadose zone in the Castile Formation could acquire all the elements that make up the sodium sulfate brines. $\mathrm{He}$ further stated that normal ground-water circulation would tend to remove the brine, but that some brines could become trapped in "inverted closures or pockets" on top of massive unaltered anhydrite of the Castile. The presence of significant amounts of magnesium, potassium, and borate in the brines (table 3 ) suggests that they are residual brines from solution of the Salado Formation which is now present in the area only as residuum at the top of the Castile Formation. Magnesium, potassium, and borate are very rare in the Castile Formation, but potassium and magnesium minerals, at least, are present in some abundance in the Salado Formation east of the Pecos River. Furthermore, all the brines known in the area occur in or just below the residuum of the Salado.

\section{GROUND WATER}

The ground-water resources of the Eddy County part of the Guadalupe Mountains area have been described by Hendrickson and Jones (1952), and Hale (1955) has reported on ground-water conditions in the upper part of Black River valley. The following discussion is in part a summary of those reports but includes minor additional comments.

The availability and quality of ground water in the Guadalupe Mountains area vary markedly from place to place, depending on the character and structure of the rocks. For purposes of discussion, the area may be divided into six areas of ground-water availability (fig. 29).

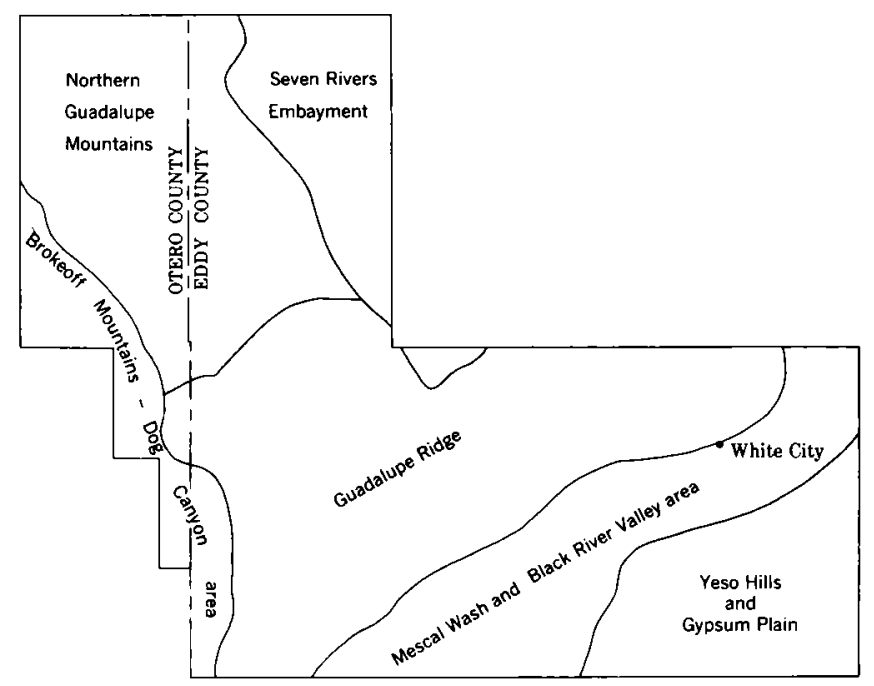

Figdre 29.-Areas of ground-water avallability discussed In text.

BROKEOFF MOUNTAINS-DOG CANYON AREA

No springs or perennial surface streams occur in the Brokeoff Mountains-Dog Canyon area, and attempts to locate a satisfactory ground-water reservoir there have failed. Nearly all the domestic and stock water used in the area is rainwater stored in cisterns and earth tanks, but a minor amount is trucked in from adjacent areas. The scarcity of available ground water probably can be attributed to the great concentration of high-angle fault planes and joints that provide avenues of drainage and to the scarcity of shallow impermeable beds that might support perched water reservoirs. Any drilling for water here will have a better chance for success if the well is located on the basis of careful study of structural and stratigraphic conditions. The ideal location would be a fault-free syncline underlain by shallow impermeable beds. However, little of 
the area is free of faults, and impermeable beds are thin and scarce north of Martine Ridge. The part of Upper Dog Canyon east of Martine Ridge may approach ideal conditions.

\section{NORTHERN GUADALUPE MOUNTAINS}

The northern Guadalupe Mountains are also without springs or perennial streams, but several drill holes have tapped water near the contact of the San Andres Limestone and the Yeso Formation at depths between 600 and 1,300 feet. It is unlikely that water in sufficient quantity for watering stock will ever be found at shallow depth in this part of the area. Small quantities of water for domestic use may be present in the alluvium of some of the larger canyons.

\section{SEVEN RIVERS EMBAYMENT}

No permanent surface streams or springs are in the Seven Rivers Embayment. Potable ground water generally is present in quantities sufficient for domestic and stock-watering uses, but its depth is difficult to predict. Wells drilled near the west edge of the embayment, on or near the San Andres Limestone outcrop, generally do not strike water at depths shallower than 600 to 900 feet, but locally the arroyo gravels may contain small quantities of water at shallow depth. Toward the east, water is obtained from the Grayburg Formation at depths of 75 to 300 feet.

\section{GUADALUPE RmgE}

The occurrence of ground water in the Guadalupe Ridge area is erratic, as it is dependent on variable local structural and stratigraphic conditions. Where structural conditions are favorable, water in sufficient quantity and of suitable quality for stock and domestic uses is often present in dolomite and limestone beds that overlie relatively impervious clastic beds in the San Andres Limestone, sandstone tongue of the Cherry Canyon Formation, the Artesia Group, and the Capitan Limestone. Where topographic conditions permit, water from these perched aquifers comes to the surface in nearly 50 seeps and springs, 2 of which maintain short stretches of surface streams. Sitting Bull Spring (sec. 9, T. 24 S., R. 22 E.), the larger of these 2 springs, emerges from a dolomite tongue of the San Andres Limestone which overlies relatively impervious clastic beds of the sandstone tongue of the Cherry Canyon Formation. The flow from the spring irrigates a small apple orchard near the mouth of Sitting Bull Canyon and furnishes drinking water to the U.S. Forest Service Recreation area (fig. 23).

The stream gravels of Dark Canyon, and possibly other canyons, locally contain important quantities of shallow ground water in the Guadalupe Ridge area. Where the limestone bedrock rises near the surface, springs emerge from the overlying alluvium in Dark Canyon in sec. 25, T. 24 S., R. 22 E., and sec. 31, T. 24 S., R. 23 E. Water from these springs is used to irrigate fields near the X-Bar Ranch headquarters.

Drilling for water in the Guadalupe Ridge area has produced numerous dry holes. Where water has been found, its depth ranges from a few feet to several hundred feet. Probably the percentage of successful water wells in the area could be increased greatly if drilling were done in synclinal areas which geologic relations indicate are underlain by relatively impervious siltstone beds that could support perched water.

\section{MESCAL WASH AND BLACK RIVFR VAILEY AREA}

The Mescal Wash and Black River valley area is underlain by more available ground water than the mountain areas. This ground water comes to the surface in nearly a dozen springs and seeps, the most notable being Blue, Rattlesnake, and Geyser Springs, each of which flows generally in excess of $1,000 \mathrm{gpm}$ (gallons per minute). Blue Spring, the largest spring, has an average flow in excess of $5,000 \mathrm{gpm}$ and furnishes irrigation water to a sizable farming development near Black River Village. The extensive gravel deposits of Mescal Wash, south of Rattlesnake Canyon and west of Black River, probably comprise the most dependable reservoirs of potable ground water in the entire report area. Here, large volumes of water are pumped for irrigation from depths of 100 to 300 feet. North and east of Rattlesnake Canyon and along Black River itself, where the gravel deposits are thin to absent, the occurrence and quality of ground water is much less predictable. In general, the waters here contain more sulfate than those in Mescal Wash and are nearly unpotable. A detailed analysis of the ground-water conditions in the Mescal Wash and Black River valley area was made by Hale (1955).

\section{FESO HILLS AND GYPSUM PLAIN}

In the Gypsum Plain, small amounts of highly gypsiferous water, probably from fractures in the Castile Formation, reach the surface at Cottonwood Spring (sec. 35, T. 25 S., R. 25 E.), Ben Slaughter Spring (sec. 7, T. 26 S., R. 26 E.), and Jumping Spring (sec. 17, T. 26 S., R. 26 E.). The surface drainage on the Castile Formation is apparently controlled by an eastwardtrending fracture system (Hayes, 1957; Olive, 1957, p. $356-357$ ), and wells drilled here in valley bottoms often tap water at shallow depth. Water from the Castile Formation or from gypsiferous alluvium derived from the Castile Formation generally is suitable for livestock, 
but a sulfate content of as much as 1,500 to $1,800 \mathrm{ppm}$ (parts per million) is not unusual (Hendrickson and Jones, 1952, p. 163-164). The only ground water known near the east edge of the area is the heavy sulfate brine discussed on pages $56-57$.

\section{SELECTED STRATIGRAPHIC SECTIONS}

About 60 stratigraphic sections were measured during the present investigation; the most useful in illustrating the stratigraphic relations are shown graphically on plate 3. Four of these sections, which can serve as reference sections, are augmented by the following generalized written descriptions. The stratigraphic section numbers refer to numbers given on plates 1 and 3 .

2. Section of Yates Formation on north wall of North Rattlesnake Canyon in W1/2 sec. 32, T. 24 S., R. 24 E., from canyon bottom opposite Bench Mark 1990 to top of hill east of trail into Walnut Canyon

Top of hill.

Thickness

Tansill Formation: Dolomite, yellowish-gray, laminated; mostly in beds 5 to $10 \mathrm{ft}$ thick; weathers light olive gray (feet)

ates Formation :

Siltstone, quartz grains and dolomite cement; weathers grayish orange; poorly exposed in slope_

Dolomite, yellowish-gray, laminated; in beds 2 to 4 in thick; weathers light olive gray-.......-..-

Siltstone, quartz grains and dolomite cement; weathers grayish orange ; poorly exposed in slope.

Dolomite, light-gray, laminated; in beds about $5 \mathrm{ft}$ thick; contains pisolites and fusulinids; weathers light olive gray

Siltstone, quartz grains and dolomite cement; weathers grayish orange

Dolomite, grayish-orange, laminated ; in beds about $3 \mathrm{ft}$ thick; contains numerous pisolites; weathers pale yellowish brown.

Siltstone, quartz grains and dolomite cement, laminated ; weathers grayish orange

Dolomite, pale-yellowish-brown, laminated ; in beds less than $1 \mathrm{ft}$ thick; weathers light olive gray.-.--

Siltstone, quartzose; weathers grayish orange; poorly exposed in slope

Dolomite, very pale orange, laminated; in beds less than $1 \mathrm{ft}$ thick; weathers grayish orange...-.---

Siltstone, quartzose ; weathers grayish orange

Dolomite, grayish-orange, laminated; in beds 1 in to $1 \mathrm{ft}$ thick; weathers pale yellowish brown; basal $51 / 2 \mathrm{ft}$ very poorly exposed.

Dolomite, yellowish-gray, laminated ; mostly in beds 2 to $5 \mathrm{ft}$ thick; contains pisolites; weathers pale yellowish brown

Dolomite, yellowish-gray; in beds less than $1 \mathrm{ft}$ thick; upper 2 ft very poorly exposed

Siltstone, grayish-orange, quartz grains and dolomite cement, laminated; in beds 1 in to $1 \mathrm{ft}$ thick ; poorly exposed in slope...-...- 11

Covered in slope

Dolomite, grayish-orange, laminated ; one bed......-

Covered in slope.

5
Yates Formation-Continued

Dolomite, grayish-orange, laminated; in beds less than $1 \mathrm{ft}$ thick; weathers pale yellowish brown.Covered; interval apparently contains thinly bedded dolomite a few hundred feet up the canyon.....-

Dolomite, grayish-orange, laminated ; in beds about 6 in thick; weathers pale yellowish brown.....-.

Siltstone, grayish-orange, quartzose ; poorly exposed in slope

Dolomite, grayish-orange, laminated ; in one bed ; contains pisolites; weathers pale yellowish brown

Siltstone, grayish-orange, quartz grains and dolomite cement, laminated; in beds 1 in to $1 \mathrm{ft}$ thick; contains iron-oxide concretions.

Dolomite, light-olive-gray, laminated; in beds 3 to $5 \mathrm{ft}$ thick; contains pisolites; weathers pale yellowish brown

Siltstone, grayish-orange, quartz grains and calcite cement, laminated.

Dolomite, silty, grayish-orange, laminated; in beds less than $1 \mathrm{ft}$ thick

Dolomite, pale-yellowish-orange, laminated ; in thick poorly defined beds; contains pisolites.-_-__-_-- 241/2

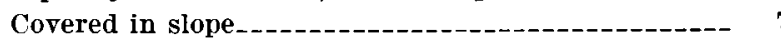

Dolomite, grayish-orange, laminated; in beds 2 in to $1 \mathrm{ft}$ thick; weathers light olive gray.-.---_--

Siltstone, grayish-orange, quartzose, laminated----

Dolomite, grayish-orange, laminated; in one bed; weathers light olive gray

Siltstone, grayish-orange, quartz grains in calcite cement; laminated; contains nodules of iron oxide

Dolomite, grayish-orange, laminated; in one bed; weathers pale yellowish brown

Dolomite, light-brown, laminated; in beds 3 in to 1 ft thick; weathers grayish orange; top $1 \frac{1}{2} \mathrm{ft}$ covered

Siltstone, grayish-orange, quartzose ; poorly exposed

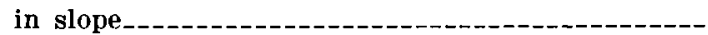
Total, Yates Formation.......... 328

Seven Rivers Formation :

Dolomite, very light gray, laminated; in beds 6 in to $5 \mathrm{ft}$ thick; weathers light olive gray--_-_-_---

Dolomite, pale-yellowish-brown; in beds about 2 in

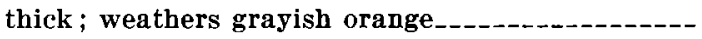

Dolomite, very light gray, laminated ; most in indistinct beds from 3 to $15 \mathrm{ft}$ thick; weathers light olive gray

Canyon bottom.

12. Section of Queen Formation on east wall of Dark Canyon from $N W 1 / 4 N E 1 / 4$ sec. 32, T. 24 S., $R$. 29 E., at canyon bottom south of abandoned CCC Camp diagonally upward to top of hill in $S E 1 / 4 S E 1 / 4$ sec. $29, T$. 24 S., R. $23 E$.

Top of hill.

Seven Rivers Formation: Dolomite, zellowish-gray, (feet)

181/2 faintly laminated; in beds 1 in to $3 \mathrm{ft}$ thick; weathers

light olive gray

Queen Formation:

Siltstone and silty shale; weathers grayish orange

Dolomite, pale-yellowish-brown, faintly laminated; in beds about 6 in thick ; weathers grayish orange.-

Siltstone, argillaceous; weathers grayish orange...Dolomite, pale-yellowish-brown, faintly laminated; in beds about 6 in thick ; weathers grayish orange-- 
Queen Formation-Continued

Siltstone, sandy, pale-yellowish-orange, variably

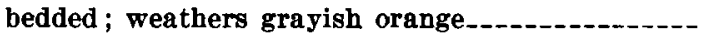

Dolomite, faintly laminated; in one bed; weathers grayish orange

Siltstone, shaly, pale-yellowish-orange; weathers grayish orange

Dolomite, yellowish-gray, laminated; one bed; weathers light olive gray

Covered; probably siltstone

Dolomite, yellowish-gray, laminated; in one bed; weathers light olive gray

Siltstone, shaly, pale-yellowish-orange; weathers

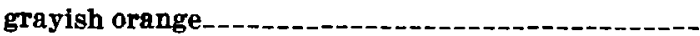

Dolomite, yellowish-orange, laminated ; one bed.---

Siltstone, shaly, pale-yellowish-orange; weathers grayish orange.

Dolomite, yellowish-gray, laminated ; one bed.-.-.--

Siltstone; sandy at base, shaly at top; very pale orange; weathers grayish orange

Dolomite, grayish-orange, faintly laminated; contains fusulinids

Siltstone, shaly, pale-yellowish-orange; weathers grayish orange

Dolomite, yellowish-gray, laminated; one bed;

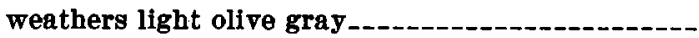

Siltstone, very poorly exposed.

Dolomite, graylsh-orange, faintly laminated; contains fusulinids

Siltstone, sandy, very pale orange, laminated ; in beds $1 / 2$ to 6 in. thick.

Dolomite, yellowish-gray, laminated; in two beds; weathers light olive gray.

Dolomite, very thinly bedded and poorly exposed; interbedded with siltstone

Dolomite, very pale orange to light olive gray; in thin to thick beds.

Dolomite, light-olive-gray, laminated; in beds about $2 \mathrm{ft}$ thick; weathers grayish orange.-

Sandstone, very pale orange, very fine grained, laminated; in beds 1 in to $1 \mathrm{ft}$ thick; weathers pale yellowish brown.

Dolomite, silty, very pale orange, laminated; in beds 1 in to $1 \mathrm{ft}$ thick ; weathers pale yellowish brown--

Siltstone, very pale orange, quartzose with dolomite cement, laminated ; contains nodules of iron oxide; in beds 6 in to $2 \mathrm{ft}$ thick; weathers pale yellowish brown

Dolomite, slightly silty, very pale orange, faintly laminated; in beds about 3 in. thick; contains scattered nodules of iron oxide in upper $3 \mathrm{ft}$; weathers pale yellowish brown.

Siltstone, very pale orange, quartzose with dolomite cement, laminated ; weathers grayish orange.-.---

Dolomite, Jellowish-gray, laminated; one bed; weathers light olive gray

Siltstone, very pale orange, quartzose with dolomite cement, laminated ; weathers grayish orange.-

Dolomite, yellowish-gray, laminated; in two beds; weathers light olive gray

Siltstone, very pale orange, quartzose with dolomite cement, laminated ; weathers grayish orange...-..-
Queen Formation-Continued Thickness

Dolomite, silty in part, very pale orange, laminated; in beds 2 in to $5 \mathrm{ft}$ thick; contains fusulinids in some beds; weathers light olive gray-_.--_-.---

Dolomite, silty, grayish-orange, faintly laminated; in beds 1 to 4 in. thick; contains scattered nodules of iron oxide.

Dolomite, silty in part, very pale orange, laminated; in beds 2 in to $5 \mathrm{ft}$ thick; weathers light olive

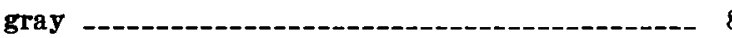

Dolomite, silty, very pale orange, laminated; in one bed ; contains nodules of iron oxide-..--..--.-.-Dolomite, very pale orange, laminated; in beds 2 in to 3 ft thick; weathers pale yellowish brown.......-

Dolomite, very sandy, grayish-orange, faintly laminated; in beds 3 to 18 in. thick, transitional into overlying dolomite and underlying sandstone

Sandstone, very pale orange, very fine grained, quartzose with dolomite cement, cross-laminated; in beds 2 to $10 \mathrm{ft}$ thick; contains numerous nodules of iron oxide; weathers pale yellowish brown

Total, Queen Formation_._._. 378

Grayburg Formation: Dolomite, yellowish-gray ; in beds 2 to $5 \mathrm{ft}$ thick

Canyon bottom.

13. Section of Seven Rivers Formation on west wall of Bear Canyon in $\$ E 1 / 4$ sec. 33, T. 24 S., R. 23 E., from canyon bottom to top of ridge. Base of overlying Yates Formation measured on opposite side of canyon

Yates Formation: Siltstone, pale yellowish orange; in beds about 1 in. thick; weathers grayish orange Seven Rivers Formation:

Dolomite, yellowish-gray, laminated ; mostly in beds 1 to $10 \mathrm{ft}$ thick; some beds contain fusulinids; weathers light olive gray

Dolomite, very silty, very thin bedded, poorly ex-

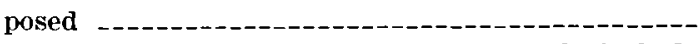

Dolomite, yellowish-gray, laminated ; mostly in beds 1 to $10 \mathrm{ft}$ thick; some beds contain fusulinids; weathers light olive gray

Dolomite, yellowish-gray, laminated; mostly in beds about $10 \mathrm{ft}$ thick; fusulinids common; weathers

light olive gray
Dolomite, yellowish-gray, faintly laminated; in beds about $1 \mathrm{ft}$ thick; weathers light olive gray-_...--- 11

Siltstone, grayish-orange ; poorly exposed in slope--- 4

Dolomite, yellowish-gray, laminated ; fusulinids abundant; weathers light olive gray

Dolomite, yellowish-gray, faintly laminated; mostly

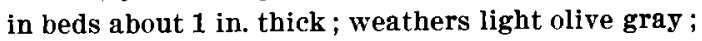

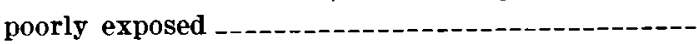

Dolomite, yellowish-gray, laminated; mostly in beds 3 to $10 \mathrm{ft}$ thick; contains some fusulinids; weathers light olive gray Thickness
(feet) 3 Dolomite, yellowish-gray, faintly laminated; in beds about $1 \mathrm{ft}$ thick; weathers light olive gray -..---.-Covered in slope; apparently contains both dolomite and siltstone
7 
Seven Rivers Formation-Continued

Dolomite, yellowish-gray, laminated ; in beds 5 to $10 \mathrm{ft}$ thick ; fusulinids abundant in some beds; weathers light olive gray

Siltstone, grayish-orange; poorly exposed in slope...

Dolomite, yellowish-gray, laminated; in beds 5 to $\mathbf{1 0}$ ft thick ; fusulinids abundant in some beds; weathers light olive gray

Siltstone, very pale orange, quartzose with dolomite cement, faintly laminated; in one bed; weathers grayish orange.

Dolomite, yellowish-gray, laminated ; in three beds; weathers light olive gray

Dolomite, very silty; weathers grayish orange

Dolomite, yellowish-gray, laminated ; in beds 5 to 10 ft thick; contains abundant fusulinids; weathers light olive gray

Siltstone, grayish-orange ; mostly covered in slope Dolomite, yellowish-gray, faintly laminated; in beds 1 to $5 \mathrm{ft}$ thick

Total, Seven Rivers Formation (feet)
hickness 18 6 $112 \frac{1}{2}$

ormation:

Siltstone, yellowish-gray, quartzose with calcite cement, laminated; in one bed; weathers light olive gray

Dolomite, very pale orange, faintly laminated ; in beds about $1 \mathrm{ft}$ thick ; contains nodules of iron oxide...-

Siltstone, very pale orange, quartzose with dolomite cement, laminated; in beds 1 in to $1 \mathrm{ft}$ thick; contains scattered nodules of iron oxide

Dolomite, some slightly silty, light-gray to yellowishgray; mostly in beds less than $1 \mathrm{ft}$ thick; some beds contain fusulinids.

Siltstone, pale yellowish-orange, quartzose with dolomite cement, faintly laminated; weathers grayish orange

Dolomite, light olive gray, laminated; in two beds; contains fusulinids ; weathers yellowish gray --.---

Dolomite, silty, very thinly bedded; mostly covered in slope

Dolomite, laminated; in one bed; weathers yellow-

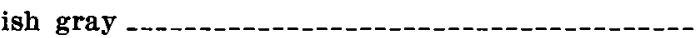

Dolomite, silty, very thinly bedded; mostly covered in slope

Dolomite, laminated; in beds about $2 \mathrm{ft}$ thick ; contains abundant fusulinids; weathers yellowish gray ------------------------------------------

Siltstone, pale-yellowish-orange, quartzose with calcite cement, faintly laminated; in beds about 1 in. thick; weathers grayish orange.

Dolomite, light olive-gray, laminated; in two beds; contains scattered fusulinids............-

Siltstone, very pale orange, quartzose with calcite cement, faintly laminated; in beds about 3 in. thick; poorly exposed in slope

Dolomite, yellowish-gray, laminated in part; in beds about 3 ft thick; fusulinids locally abundant; weathers light olive gray

Dolomite, silty, very pale orange; in one bed.--.---

Dolomite, yellowish-gray, laminated in part; in beds 3 to $10 \mathrm{ft}$ thick; fusulinids abundant in some beds ; weathers light olive gray
Queen Formation-Continued Thickness

Siltstone, grayish-orange, quartzose with dolomite cement, faintly laminated; in beds 3 in to $1 \mathrm{ft}$ thick; contains scattered nodules of iron oxide--..---.--

Dolomite, yellowish-gray, laminated; in beds 3 to $5 \mathrm{ft}$ thick; contains abundant fusulinids; weathers light olive gray

Dolomite, very silty, very pale orange, laminated in part; in beds about $2 \mathrm{ft}$ thick; weathers grayish orange

\section{$\mathbf{3}$}

Total exposed, Queen Formation Canyon bottom.

18. Section of Grayburg Formation on Shattuck Valley Escarpment from $W 1 / 2 S W 1 / 4$ sec. $16, T .25 S ., R .21 \mathrm{E}$., to near top of escarpment. Upper beds were traced southward and measured near center of sec. 21, T. $25 \mathrm{~S} ., \mathrm{R} .21 \mathrm{E}$.

Thickness (feet)

20 Queen Formation: Sandstone, very pale orange, very fine grained, quartzose with calcite cement; in beds 1 in to 2 ft thick

Grayburg Formation:

Dolomite, very light gray to very pale orange; in beds 2 to $5 \mathrm{ft}$ thick; weathers light olive gray--_----- 43

Dolomite, sandy, grayish-orange, very thinly bedded_

Dolomite, yellowish-gray ; in beds 1 in to $1 \mathrm{ft}$ thick

Covered in slope.

Dolomite, yellowish-gray; one bed.

Sandstone, silty, very light gray to pale-yellowishgray, very fine grained; quartzose with calcite cement, laminated; mostly in beds less than 6 in. thick; weathers pale yellowish brown

Dolomite, yellowish-gray; mostly in beds 5 to $10 \mathrm{ft}$

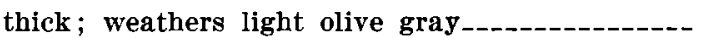

Siltstone, sandy, very light gray, quartzose with calcite cement; grades into overlying dolomite_---

Dolomite, light-gray; in beds about 2 ft thick; weathers light olive gray

Dolomite, very sandy, light-gray; transitional into underlying sandstone and overlying dolomite-----

Sandstone, very light gray, very fine grained, quartzose with calcite cement; in two beds; weathers pale yellowish brown

Dolomite, light-gray; in beds 1 to $6 \mathrm{ft}$ thick; weathers light olive gray.

Covered interval; probably sandy dolomite in lower part and fine-grained sandstone in upper part.--

Dolomite, yellowish-gray; in beds 1 to $4 \mathrm{ft}$ thick; weathers pale yellowish brown

Covered in slope.

Limestone, dolomitic, sandy, grayish-orange ; in beds 2 in to $2 \mathrm{ft}$ thick ; weathers pale yellowish brown

Sandstone, very pale orange, very fine grained, quartzose with calcite cement; in irregular beds 1 in to $1 \mathrm{ft}$ thick; weathers grayish orange

Limestone, dolomitic, yellowish-gray, laminated in beds 2 to $4 \mathrm{ft}$ thick; weathers pale yellowish orange

Covered in slope

Dolomite, calcareous, very pale orange, laminated; in beds 1 to $4 \mathrm{ft}$ thick; weathers pale yellowish orange 
Grayburg Formation-Continued

Dolomite, very thinly bedded; weathers grayish orange ; very poorly exposed.

Dolomite, pale-yellowish-orange; in beds 1 to $2 \mathrm{ft}$ thick; weathers very pale orange.

Sandstone, very fine grained, quartzose with calcite cement ; weathers grayish orange ; poorly exposed.

Limestone, dolomitic, slightly sandy, very pale orange, oolitic near base; in beds 1 to $4 \mathrm{ft}$ thick; weathers pale yellowish brown

Limestone, dolomitic, very sandy at base, yellowishgray, faintly laminated; a $6 \mathrm{ft}$-thick bed at base and beds less than $1 \mathrm{ft}$ thick at top; weathers pale yellowish brown; poorly exposed at top.

Sandstone, silty, very pale orauge, very fine grained; in beds 6 in to $1 \mathrm{ft}$ thick; weathers yellowish gray; grades into overlying limestone

Dolomite, very pale orange; in beds 6 in to $3 \mathrm{ft}$ thick

Sandstone, silty, very pale orange, very fine grained; in beds 6 in to $1 \mathrm{ft}$ thick; weather yellowish gray ; grades into overlying limestone.

Dolomite, sandy, pale-yellowish-brown, laminated ; in beds 3 in to $3 \mathrm{ft}$ thick; weathers pale sellowish orange

Sandstone, pale-yellowish-orange, very fine grained, quartoze with calcite cement; in beds 2 to 6 in. thick; weathers grayish orange

Limestone, dolomitic, grayish-orange, laminated; in beds 1 in to $1 \mathrm{ft}$ thick; weathers pale yellowish brown

Sandstone, pale-yellowish-orange, very fine grained, quartzose with calcite cement; very poorly exposed

cement; very poorly

Total, Grayburg Formation

San Andres Limestone: Limestone. dolomitic, very pale orange, thickly bedded; contains fusulinid molds; Fault. weathers pale yellowish brown

\section{REFERENCES CITED}

Adams, J. E., 1944, Opper Permian Ochoa series of Delaware Basin, West Texas and southeastern New Mexico: Am. Assoc. Petroleum Geologists Bull., v. 28, no. 11, p. 1596-1625.

Adams, J. E., Cheney, M. G., DeFord, R. K., Dickey, R. I., Dunbar, C. O., Hills, J. M., King, R. E., Lloyd, E. R., Miller, A. K., and Needham, C. E., 1939, Standard Permian section of North America: Am. Assoc. Petroleum Geologists Bull., v. 23 , no. 11 , p. $1673-1681$.

Adams, J. E., and Frenzel, H. N., 1950, Capitan barrier reef, Texas and New Mexico: Jour. Geology, v. 58, no. 4, p. 289 312.

Adams, J. E., and Rhodes, M. L., 1960, Dolomitization by seepage refluxion: Am. Assoc. Petroleum Geologists Bull., v. 44, no. 12, p. 1912-1920.

Bachman, G. O., and Hayes, P. T., 1958, Stratigraphy of Upper Pennsylvanian and lower Permian rocks in the Sand Canyon area, Otero County, New Mexico : Geol. Soc. America Bull., v. 69 , no. 6, p. 689-700.

Baker, C. L., 1920, Contributions to the stratigraphy of eastern New Mexico: Am. Jour. Sci., 4th ser., v. 49, p. 99-126.
Bates, R. L., 1942a, Lateral gradation in the Seven Rivers formation, Rocky Arroyo, Eddy County, New Mexico: Am. Assoc. Petroleum Geologists Bull., v. 26, no. 1, p. 80-99.

$1942 b$, The oil and gas resources of New Mexico: $2 d$ ed., New Mexico School Mines Bull. 18, 320 p.

Beede, J. W., 1910, The correlation of the Guadalupian and the Kansas sections : Am. Jour. Sci., 4th ser., v. 30, p. 131-140.

Black, D. M., 1956, Chinese walls of New Cave, Carlsbad Caverns National Park [N. Mex.] : Science, v. 123, no. 3204, p. 937938.

Black, T. H., 1954, The origin and development of the Carlsbad Caverns: in New Mexico Geol. Soc. Guidebook, 5th Field Conf., October 1954 : p. 136-142.

Blanchard, W. G., Jr., and Davis, M. J., 1929, Permian stratigraphy and structure of parts of southeastern New Mexico and southwestern Texas: Am. Assoc. Petroleum Geologists Bull., v. 13, no. 8, p. 957-995.

Boyd, D. W., 1955, Stratigraphy of the Brokeoff Mountains, New Mexico: in Soc. Econ. Paleontologists and Mineralogists, Permian Basin Sec., Permian Field Conf., October 1955: p. 47-51.

— 1958, Permian sedimentary facies, central Guadalupe Mountains, New Mexico: New Mexico Bur. Mines and Mineral Resources Bull. 49, 100 p.

Bradley, W. C., 1958, Exfoliation due to release of confining pressure in massive sandstones of the Colorado Plateau [abs.] : Geol. Soc. America Bull., v. 69, no. 12, pt. 2, p. 1724.

Bretz, J. H., 1942, Vadose and phreatic features of limestone caverns: Jour. Geology, v. 50, no. 6, pt. 2, p. 675-811.

1949, Carlsbad Caverns and other caves of the Guadalupe block, New Mexico: Jour. Geology, v. 57, no. 5, p. 447-463.

Burnet, R. M. P., 1938, Exploring a new cave-remains of animals and pottery 1,000 years old are found amid unearthly splendors of a recently discovered cavern in the Guadalupe Mountains of New Mexico: Nat. History, v. 41, no. 5, p. 374-383.

Cartwright, L. D., Jr., 1930, Transverse section of Permian basin, west Texas and southeast New Mexico: Am. Assoc. Petroleum Geologists Bull., v. 14, no. 8, p. 969-981.

Cave, H. S., 1954, The Capitan-Castile-Delaware Mountain problem, in New Mexico Geol. Soc. Guidebook, 5th Field Conf., October 1954: p. 117-124.

Clifton, R. L., 1945, Permian Word formation; its faunal and stratigraphic correlatives, Texas: Am. Assoc. Petroleum Geologists Bull., v. 29, no. 12, p. 1766-1776.

Crandall, K. H., 1929, Permian stratigraphy of southeastern New Mexico and adjacent parts of western Texas: Am. Assoc. Petroleum Geologists Bull., v. 13, no. 8, p. 927-944.

Crisman, B. L., 1960, Other caves in the vicinity, in Spangle, P. F., ed., Guidebook to Carlsbad Caverns National Park [N. Mex.] : Natl. Speleol. Soc. Guidebook Series No. 1, p. 3135.

Dane, C. H., and Bachman, G. O., 1958, Preliminary geologic map of the southeastern part of New Mexico: U.S. Geol. Survey Misc. Geol. Inv. Map I-256.

Darton, N. H., 1917, A comparison of Paleozoic sections in southern New Mexico: U.S. Geol. Survey Prof. Paper 108-C, p. 31-55.

1922, Geologic structure of parts of New Mexico: U.S. Geol. Survey Bull. 726-E, p. 173-275.

Darton, N. H., and Reeside, J. B., Jr., 1926, Guadalupe group : Geol. Soc. America Bull., v. 37, no. 3, p. 413-428. 
Davies, W. E., and Moore, G. W., 1957, Endellite and hydromagnesite from Carlsbad Caverns [N. Mex.]: Natl. Speleol. Soc. Bull. 19, p. 24-27.

Davis, W. M., 1930, Origin of limestone caverns: Geol. Soc. America Bull., v. 41, no. 3, p. 475-628.

DeFord, R. K., and Lloyd, E. R., 1940, Editorial introduction, pt. 1 of West Texas-New Mexico symposium: Am. Assoc. Petroleum Geologists Bull., v. 24, no. 1, p. 1-14.

DeFord, R. K., and Riggs, G. D., 1941, Tansill formation, west Texas and southeastern New Mexico: Am. Assoc. Petroleum Geologists Bull., v. 25, no. 9, p. 1713-1728.

DeFord, R. K., Riggs, G. D., and Wills, N. H., 1938, Surface and subsurface formations, Eddy County, New Mexico [abs.] : Am. Assoc. Petroleum Geologists Bull., v. 22, no. 12, p. 1706-1707.

Dickey, R. I., 1940, Geologic section from Fisher County through Andrews County, Texas, to Eddy County, New Mexico, in DeFord and Lloyd, eds., West Texas-New Mexico symposium, pt. 1: Am. Assoc. Petroleum Geologists Bull., v. 24, no. 1, p. 37-51.

Donegan, Ben, and DeFord, R. K., 1950, Ochoa is Permian : Am. Assoc. Petroleum Geologists Bull., v. 34, no. 12, p. 23562359.

Dunbar, C. O., and Skinner, J. W., 1937, Permian Fusulinidae of Texas: Texas Univ. Bull. 3701, p. 517-825.

Dunbar, C. O., Skinner, J. W., and King, R. E., 1935, Dimorphism in Permian fusulines: Texas Univ. Bull. 3501, p. 173-190.

Fenneman, N. M., 1931, Physiography of western United States: New York, McGraw-Hill Book Co., 534 p.

Fiedler, A. G., and Nye, S. S., 1933, Geology and ground-water resources of the Roswell artesian basin, New Mexico: U.S. Geol. Survey Water-Supply Paper 639, 372 p.

Flawn, P. T., 1956, Basement rocks of Texas and southeast New Mexico: Texas Univ. Pub. 5605, $261 \mathrm{p}$.

Flower, R. H., 1953, Age of Bliss sandstone, New Mexico: Am. Assoc. Petroleum Geologists Bull., v. 37, no. 8, p. 2054-2055. 1959, Cambrian-Devonian beds of southern New Mexico, in Soc. Econ. Paleontologists and Mineralogists, Permian Basin Sec., and Roswell Geol. Soc. Guidebook, Joint Field Conf., April 1959: p. 154-171.

Foster, R. W., 1959, Precambrian rocks of the Sacramento Mountains and vicinity, in Soc. Econ. Paleontologists and Mineralogists, Permian Basin Sec., and Roswell Geol. Soc. Guidebook, Joint Field Conf., April 1959: p. 137-153.

Fritz, W. C., and FitzGerald, James, Jr., 1940, South-north cross section from Pecos County through Ector County, Texas to Roosevelt County, New Mexico, in DeFord and Lloyd, eds., West Texas-New Mexico symposium, pt. 1: Am. Assoc. Petroleum Geologists Bull., v. 24, no. 1, p. 15-28.

Gardner, J. H., 1935, Origin and development of limestone caverns: Geol. Soc. America Bull., v. 46, no. 8, p. 1255-1274.

Gester, G. C., and Hawley, H. J., 1929, Yates field, Pecos County, Texas, in Structure of typical American oil fields, v. 2, p. 480-499: Tulsa, Okla., Am. Assoc. Petroleum Geologists.

Girty, G. H., 1902, The upper Permian in western Texas: Am. Jour. Sci., 4th ser., v. 14, p. 363-368.

1908, The Guadalupian fauna: U.S. Geol. Survey Prof. Paper 58, 651 p.

Goddard, E. N., chm., and others, 1948, Rock-color chart: Washington, Natl. Research Council, (republished by Geol. Soc. America, 1951), $6 \mathrm{p}$.

Good, J. M., 1957, Non-carbonate deposits of Carlsbad Caverns [N. Mex.] : Natl. Speleol. Soc. Bull. 19, p. 11-23.
Gordon, C. H., 1907, Mississippian (Lower Carboniferous) formations in the Rio Grande Valley, New Mexico: Am. Jour. Sci., 4th ser., v. 24, p. 58-64.

Hale, W. E., 1955, Ground-water conditions in the vicinity of Rattlesnake Springs, Eddy County, New Mexico: New Mexico State Engineer Office Tech. Rept., no. 3, 54 p.

Hayes, P. T., 1957, Geology of the Carisbad Caverns East quadrangle, New Mexico, with a chapter on geologic development of the Carlsbad Caverns by B. T. Gale: U.S. Geol. Survey Geol. Quad. Map GQ-98.

1959, San Andres limestone and related Permian rocks in Last Chance Canyon and vicinity, southeastern New Mexico: Am. Assoc. Petroleum Geologists Bull., v. 43, no. 9, p. 2197-2213.

Hayes, P. T., and Koogle, R. L., 1958, Geology of the Carlsbad Caverns West quadrangle, New Mexico-Texas: U.S. Geol. Survey Geol. Quad. Map GQ-112 [1959].

Hendrickson, G. E., and Jones, R. S., 1952, Geology and groundwater resources of Eddy County, New Mexico: New Mexico Bur. Mines and Mineral Res. Ground-water Rept. 3, 169 p.

Herrick, C. L., 1900, The geology of the White Sands of New Mexico: Jour. Geology, v. 8, no. 2, p. 112-128.

Horberg, C. L., 1949, Geomorphic history of the Carlsbad Caverns area, New Mexico: Jour. Geology, v. 57, no. 5, p. 464-476.

Howard, E. B., 1935, Evidence of early man in North America : Museum Jour., v. 24, nos. 2-3, p. 61-175.

Howe, H. J., 1959, Montoya group stratigraphy (Ordovician) of Trans-Pecos Texas [-N. Mex.] : Am. Assoc. Petroleum Geologists Bull., v. 43, no. 10, p. 2285-2332.

Hull, J. P. D., Jr., 1957, Petrogenesis of Permian Delaware Mountain sandstone, Texas and New Mexico: Am. Assoc. Petroleum Geologists Bull., v. 41, no. 2, p. 278-307.

Jaffe, H. W., Gottfried, David, Waring, C. L., and Worthing, H. W., 1959, Lead-alpha age determinations of accessory minerals of igneous rocks (1953-1957) : U.S. Geol. Survey Bull. 1097-B, p. 65-148.

Jenney, W. P., 1874, Notes on the geology of western Texas near the thirty-second parallel: Am. Jour. Sci., 3d ser., v. 7, p. 25-28.

Johnson, J. H., 1942, Permian lime-secreting algae from the Guadalupe Mountains, New Mexico: Geol. Soc. America Bull., v. 53, no. 2, p. 195-226.

Jones, C. L., 1954, The occurrence and distribution of potash minerals in southeastern New Mexico, in New Mexico Geol. Soc. Guidebook, 5th Field Conf., October 1954: p. 107-112.

Jones, T. S., 1953, Stratigraphy of the Permian basin of west Texas: [New York, John Wiley \& Sons], West Texas Geol. Soc., $63 \mathrm{p}$.

Kelley, V. C., 1951, Oölitic iron deposits of New Mexico: Am. Assoc. Petroleum Geologists Bull., v. 35, no. 10, p. 2199-2228.

Kelley, V. C., and Silver, Caswell, 1952, Geology of the Caballo Mountains : New Mexico Univ. Pub. Geology, no. 4, 286 p.

King, P. B., 1934, Permian stratigraphy of trans-Pecos Texas: Geol. Soc. America Bull., v. 45, no. 4, p. 697-798.

1937, Geology of the Marathon region, Texas: U.S. Geol. Survey Prof. Paper 187, 148 p.

- 1940, Older rocks of Van Horn region, Texas, in DeFord and Lloyd. eds., West Texas-New Mexico symposium, pt. 1 : Am. Assoc. Petroleum Geologists Bull., v. 24, no. 1, p. 143156.

1942, Permian of west Texas and southeastern New Mexico, pt. 2 of DeFord and Lloyd, eds., West Texas-New Mexico symposium: Am. Assoc. Petroleum Geologists Bull., v. 26, no. 4 , p. $535-763$. 
King, P. B., 1948, Geology of the southern Guadalupe Mountains, Texas: U.S. Geol. Survey Prof. Paper 215, 183 p.

- 1949, Regional geologic map of parts of Culberson and Hudspeth Counties, Texas: U.S. Geol. Survey Oil and Gas Inv. Prelim. Map 90.

- 1964, Geology of the Sierra Diablo region, Texas: U.S. Geol. Survey Prof. Paper 480, in press.

King, P. B., and Flawn, P. T., 1953, Geology and mineral deposits of Pre-Cambrian rocks of the Van Horn area, Texas; Texas Univ. Pub. 5301, 218 p.

King, P. B., and King, R. E., 1929, Stratigraphy of outcropping Carboniferous and Permian rocks of trans-Pecos Teras: Am. Assoc. Petroleum Geologists Bull., v. 13, no. 8, p. 907926.

King, P. B., King, R. E., and Knight, J. B., 1945, Geology of the Hueco Mountains, Fl Paso and Hudspeth Counties, Texas, 1945 : U.S. Geol. Survey Oil and Gas Inv. Prelim. Map 36, 2 sheets.

King, P. B., and Knight, J. B., 1944, Sierra Diablo region, Hudspeth and Culberson Counties, Texas [1943?]: U.S. Geol. Survey Oil and Gas Inv. Prelim. Map 2.

King, P. B., and Newell, N. D., 1956, McCombs limestone member of Bell Canyon formation, Guadalupe Mountains, Texas: Am. Assoc. Petroleum Geologists Bull., v. 40, no. 2, p. 386387.

King, R. E., 1945, Stratigraphy and oil-producing zones of the pre-San Andres formations of southeastern New Mexico, a preliminary report: New Mexico Bur. Mines and Mineral Resources Bull. 23, 31 p.

King, R. H., 1947, Sedimentation in Permian Castile Sea [U.S.] : Am. Assoc. Petroleum Geologists Bull., v. 31, no. 3, p. 470 477.

Kottlowski, F. E., Flower, R. H., Thompson, M. L., and Foster, R. W., 1956, Stratigraphic studies of the San Andres Mountains, New Mexico: New Mexico Bur. Mines and Mineral Resources Mem. 1, 132 p.

Lang, W. T. B., 1937, The Permian formations of the Pecos valley of New Mexico and Texas: Am. Assoc. Petroleum Geologists Bull., v. 21, no. 7, p. 833-898.

1938, Geology of the Pecos River between Laguna Grande de La Sal and Pierce Canyon: New Mexico State Engineer 12th and 13th Bien. Rept., p. 80-86.

1941, New source for sodium sulphate in New Mexico: Am. Assoc. Petroleum Geologists Bull., v. 25, no. 1, p. 152160 .

1947, Occurrence of Comanche rocks in Black River Valley, New Mexico: Am. Assoc. Petroleum Geologists Bull., v. 31 , no. 8 , p. $1472-1478$.

Laudon, L. R., and Bowsher, A. L., 1949, Mississipplan formations of southwestern New Mexico: Geol. Soc. America Bull., v. 60, no. 1, p. 1-37.

Lee, W. T., 1909, Stratigraphy of the Manzano group of the Rio Grande valley, New Mexico: U.S. Geol. Survey Bull. 389, $141 \mathrm{p}$.

1925, New discoveries in Carlsbad Cavern [N. Mex.]: Natl. Geog. Mag., v. 48, no. 3, p. 301-319.

LeMay, W. J., 1961, Oll accumulations along Abo reefing, southeastern New Mexico [abs.] : Am. Assoc. Petroleum Geologists Bull., v. 45, no. 1, p. 125-126.

Lloyd, E. R., 1929, Capitan limestone and associated formations of New Mexico and Texas: Am. Assoc. Petroleum Geologists Bull., v. 13, no. 6, p. 645-658.
Lloyd, E. R., 1949, Pre-San Andres stratigraphy and oil-producing zones in southeastern New Mexico, a progress report: New Mexico Bur. Mines and Mineral Resources Bull. 29, 79 p.

McKee, E. D., Oriel, S. S., Ketner, K. B., MacLachlan, M. E., Goldsmith, J. W., MacLachlan, J. C., and Mudge, M. R., 1959, Paleotectonic maps of the Triassic system: U.S. Geol. Survey Misc. Geol. Inv. Map I-300.

Masson, P. H., 1956, Age of igneous rocks at Pump Station Hills, Hudspeth County, Texas: Am. Assoc. Petroleum Geologists Bull., v. 40, no. 3, p. 501-518.

Meinzer, O. E., Renick, B. C., and Bryan, Kirk, 1926, Geology of No. 3 reservoir site of the Carlsbad irrigation project, New Mexico, with respect to water-tightness: U.S. Geol. Survey Water-Supply Paper 580-A, p. 1-39.

Moore, G. W., 1959, Alteration of gypsum to form the Capitan limestone of New Mexico and Texas [abs.]: Geol. Soc. America Bull., v. 70, no. 12, pt. 2, p. 1647.

1960, Geology of Carlsbad Caverns, New Mexico, in Spangle, P. F., ed., Guidebook to Carlsbad Caverns National Park: Natl. Speleol. Soc. Guidebook Series No. 1, p. $10-18$.

Moran, W. R., 1954, Proposed type sections for the Queen and Grayburg formations of Guadalupe age in the Guadalupe Mountains, Eddy County, New Mexico [abs.]: Geol. Soc. America Bull., v. 65, no. 12, pt. 2, p. 1288; New Mexico Geol. Soc. Guidebook, 5th Field Conf., October 1954, p. 147-150. 1955, Sandstone in New Mexico Room of Carlsbad Caverns, New Mexico: Am Assoc. Petroleum Geologists Bull., v. 39, no. 2, p. 256-259.

Motts, W. S., 1959, Age of the Carlsbad Caverns and related caves in rocks of Guadalupe age west of the Pecos River in southeastern New Mexico [abs.] : Geol. Soc. America Bull., v. 70, no. 12 , pt. 2 , p. 1737 .

1962, Geology of the West Carlsbad quadrangle, New Mexico: U.S. Geol. Survey Geol. Quad. Map GQ-167.

Needham, C. E., 1937, Some New Mexico Fusulinidae: New Mexico School Mines Bull. 14, 88 p.

Needham, C. E., and Bates, R. L., 1943, Permian type sections in central New Mexico: Geol. Soc. America Bull., v. 54, no. 11 , p. $1653-1667$.

Newell, N. D., Rigby, J. K., Fischer, A. G., Whiteman, A. J., Hickox, J. E., and Bradley, J. S., 1953, The Permian reef complex of the Guadalupe Mountains region, Texas and New Mexico-a study in paleoecology: San Francisco, Calif., W. H. Freeman \& Co., 236 p.

Olive, W. W., 1957, Solution-subsidence troughs, Castlle formation of Gypsum Plain, Texas and New Mexico: Geol. Soc. America Bull., v. 68, no. 3, p. 351-358.

Otte, Carel, Jr., 1959, The Laborcita formation of late Virgllianearly Wolfcampian age of the northern Sacramento Mountains, Otero County, New Mexico, in Soc. Econ. Paleontologists and Mineralogists, Permian Basin Sec. [and] Roswell Geol. Soc. Guidebook, Joint Field Conf., April 1959: p. 196-208.

Podpechan, F. W., 1959, New Empire Abo strikes rush to southeast New Mexico : Oil and Gas Jour., v. 57, no. 26, p. 148-151.

Pratt, W. E., 1954, Evidences of igneous activity in the northwestern part of the Delaware basin, in New Mexico Geol. Soc. Guidebook, 5th Field Conf., October 1954: p. 143-147.

Pray, L. C., 1954, Outline of the stratigraphy and structure of the Sacramento Mountain escarpment, in New Mexico Geol. Soc. Guidebook, 5th Field Conf., October 1954: p. 92-107. 
Pray, L. C., 1959, Stratigraphic and structural features of the Sacramento Mountain escarpment, New Mexjco, in Soc. Econ. Paleontologists and Mineralogists, Permian Basin Sec. [and] Roswell Geol. Soc. Guidebook, Joint Field Conf., April 1959: p. 86-130.

Pray, L. C., and Allen, J. E., 1956, Outlier of Dakota (?) strata, southeastern New Mexico: Am. Assoc. Petroleum Geologists Bull., v. 40, no. 11, p. 2735-2740.

Read, C. B., and Wood, G. H., Jr., 1947, Distribution and correlation of Pennsylvanian rocks in late Paleozoic sedimentary basins of northern New Mexico, in Wanless, H.R., Symposium on Pennsylvanian problems: Jour. Geology, v. 55, no. 3 , pt. 2 , p. $220-236$.

Richardson, G. B., 1904, Report of a reconnaissance in TransPecos Texas, north of the Texas and Pacific Railway: Texas Univ. Mineral Survey Bull. 9 [and] Texas Univ. Bull. 23, $119 \mathrm{p}$.

- 1908, Paleozoic formations in Trans-Pecos Texas: Am. Jour. Sci., 4th ser., v. 25, p. 474-484.

1909, Description of the El Paso district: U.S. Geol. Survey Geol. Atlas, Folio 166, 11 p.

1910, Stratigraphy of the upper Carboniferous in west Texas and southeast New Mexico: Am. Jour. Sci., 4th ser., v. 29, p. 325-337.

Ruedemann, Rudolf, 1929, Coralline algae, Guadalupe Mountains: Am. Assoc. Petroleum Geologists Bull., v. 13, no. 8, p. 1079-1080.

Schultz, C. B., and Howard, E. B., 1935, The fauna of Burnet Cave, Guadalupe Mountains, New Mexico: Philadelphia Acad. Nat. Sci. Proc., v. 87, p. 273-298.

Scruton, P. C., 1953, Deposition of evaporites: Am. Assoc. Petroleum Geologists Bull., v. 37, no. 11, p. 2498-2512.

Shumard, B. F., 1858, Notice of new fossils from the Permian strata of New Mexico and Texas, collected by Dr. George G. Shumard, geologist for the United States government expedition for obtaining water by means of artesian wells along the 32d parallel, under the direction of Capt. John Pope, U.S. Top. Eng.: St. Louis Acad. Sci. Trans., v. 1, p. 290-297 [1860].

Shumard, G. G., 1858, Observations on the geological formation of the country between the Rio Pecos and the Rio Grande, in New Mexico, near the line of the 32d parallel: St. Louis Acad. Sci. Trans., v. 1, p. 273-279 [1860].

Skinner, J. W., 1946, Correlation of Permian of west Texas and southeast New Mexico: Am. Assoc. Petroleum Geologists Bull., v. 30, no. 11, p. 1857-1874.

Skinner, J. W., and Wilde, G .L., 1954, The fusulinid subfamily Boultoniinae: Jour. Paleontology, v. 28, no. 4, p. 434-444.

1955, New fusulinids from the Permian of West Texas : Jour. Paleontology, v. 29, no. 6, p. 927-940.

Stevenson, F. V., 1945, Devonian of New Mexico: Jour. Geology, v. 53, no. 4, p. 217-245.

Stipp, T. F., chm., 1951, Permian stratigraphy of the Capitan reef area of the southern Guadalupe Mountains, New Mexico : Roswell Geol. Soc. Guidebook, Field Trip, no. 4, May 11-12, 1951 : $19 \mathrm{p}$.
Stipp, T. F., 1952, Surface structures of the foothill region of the Sacramento and Guadalupe Mountains, Chaves, Eddy, Lincoln, and Otero Counties, New Mexico: Roswell Geol. Soc. Guidebook, Field Trip, no. 6, May 9-10, 1952, $14 \mathrm{p}$.

Stipp, T. F., Helmig, P. D., Alcorn, Rex, and Murphy, R. E., eds., 1956, The oil and gas fields of southeastern New Mexico; a symposium : Roswell Geol. Soc., 376 p. [1957].

Swinnerton, A. C., 1932, Origin of limestone caverns: Geol. Soc. America Bull., v. 43, no. 3, p. 663-693.

Taff, J. A., 1902, Description of the Atoka quadrangle: U.S. Geol. Survey Geol. Atlas, Folio 79, 8 p.

Tait, D. B., Ahlen, J. L., Gordon, A., Scott, G. L., Motts, W. S., and Spitler, M. E., 1962, Artesia Group of New Mexico and west Texas: Am. Assoc. Petroleum Geologists Bull., v. 46, no. 4 , p. $504-517$.

Tarr, R. S., 1892, Reconnoissance of the Guadalupe Mountains: Texas Geol. Survey Bull. 3, 42 p.

Thompson, M. L., 1942, Pennsylvanian system in New Mexico: New Mexico School Mines Bull. 17, 90 p.

Udden, J. A., 1917, Notes on the geology of Glass Mountains : Texas Univ. Bull. 1753, $59 \mathrm{p}$.

- 1924, Laminated anhydrite in Texas : Geol. Soc. America Bull., v. 35, no. 2, p. 347-354.

Walter, J. C., Jr., 1953, Paleontology of the Rustler formation, Culberson County, Texas: Jour. Paleontology, v. 27, no. 5. p. 679-702.

Warren, W. C., 1955, Introduction to field trip, in Soc. Econ. Paleontologists and Mineralogists, Permian Basin Sec., Permian Field Conf., October 1955 : p. 11-14.

Wentworth, C. K., 1922, A scale of grade and class terms for clastic sediments: Jour. Geology, v. 30, no. 5, p. 377-392.

West Texas Geological Society, 1949, Guidebook Field Trip no. 5, Pre-Permian rocks of Trans-Pecos area [Texas] and southern New Mexico, November 6-9, 1949: 67 p.

Wilde, G. L., 1955, Permian fusulinids of the Guadalupe Mountains [N. Mex.-Texas], in Soc. Econ. Paleontologists and Mineralogists, Permian Basin Sec., Permian Field Conf., October 1955: p. 59-62.

Williams, H. L., 1953, Resume of west Texas Permian invertebrate fossils, in Jones, T. S., Stratigraphy of the Permian basin of west Texas: [New York, John Wiley \& Sons], West Texas Geol. Soc., p. 58-63.

Willis, Robin, 1929, Structural development and oil accumulation in Texas Permian: Am. Assoc. Petroleum Geologists Bull., v. 13, no. 8, p. 1033-1043.

Wilpolt, R. H., MacAlpin, A. J., Bates, R. L., and Vorbe, Georges, 1946, Geologic map and stratigraphic sections of Paleozoic rocks of Joyita Hills, Los Piños Mountains, and northern Chupadera Mesa, Valencia, Torrance, and Socorro Counties, New Mexico: U.S. Geol. Survey Oil and Gas Inv. Prelim. Map 61.

Woods, E. H., 1940, South-north cross section from Pecos County, through Winkler County, Texas, to Roosevelt County, New Mexico, in DeFord and Lloyd, eds., West Texas-New Mexico symposium, pt. 1: Am. Assoc. Petroleum Geologists Bull., v. 24, no. 1, p. 29-36. 



\section{INDEX}

[Italic page numbers indicate major references]

A

Page

Abo reefs. 23

Abo Sandstone.

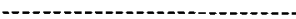

Actedgments.

Adams, J. E., quoted.

Aleman Cherty Member of the Montoya Dolomite

Aleman Formation

Algae.

Algerita Escarpment

Alluvium, Quaternary............. $\$ 8$

Anhydrite... 16, 23, 33, 35

Apache Mountains, Tex

Artesia Group.......... 19, 20, 21, $28,38,48,45,48,50$

Artesia red sand of subsurface usage . . .

Azotea Mesa.

Azotea Tongue

33

\section{B}

Besin-margin area, rocks. . . . ........... 12,13,15, 16 Bat Cave Limestone. . . Bauerdorf Schrup 1 well._.

Baylor Mountains......................... 5,7

Bear Canyon

Bell Canyon Formation.....-. 12, 15, 19, 20, 22, 40, 53

Ben Slaughter Draw . . . . .

Ben Slaughter Spring

Berlin Tank ... 43

Big Canyod . 20,22

Big Dog Canyon. ..................... 40,44, 46

Big Dog Canyon searp. . . ..... 43,46

Biotite. . . .

Black, T. H., quoted

Black River....................... 3, $98,39,47,48,54$

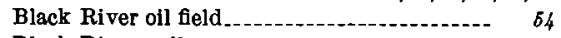

Black River valley -

Black River valley area, ground water........- $\quad 68$

Black River Village.

Blackdom terrace

Bliss Sandstono

Blue Ridge.-- 30

Blue Spring - .

Bone Canyon Member of Leonard Formation_ $\quad 10$

Bone Spring arch...................... 4k, 49, 52

Bone Spring Limestone .............. 10, 23, 24, 28, 51

future possibility of oil production..... 56

Bone Spring monocline:-_-_... 12,17, 28, 40, 4\&, 51

"Bone Springs arch"

Bone Springs Limestone.................. 10

Box Canyon.......... 30

Boyd, D. W., quoted.... 35, 36

Breccia member of Capitan Limestone. $20,21,52,53$

Brokeoff Mountains._._- 3, 17, 24, 27, 40, 43, 44, 45, 46

Brokeoff Mountains-Dog Canyon area, ground water................. 57

Brokeoff Mountains fault zone.......... 45

Brushy Canyon Formation

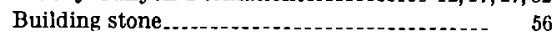

Burnet Cave. ...... 43, 50

Bursum Formation ..................... 22

\section{C}

Caballo Mountains, N. Mex................... 7

Cable Canyon Sandstone Member of Montoya

Dolomite.

\section{Page}

Calamity Cove.................. 45, 48

Calcareous tufa

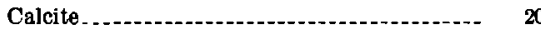

Cambrian age.

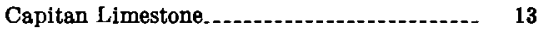

$15,19,92,35,38,49,45,46,48,62,53$

Carbonate facies of Artesia Group. ..... 28, 38,38

Carlsbad Cavern

Carlsbad Caverns National Park . . ......... 3,56

Carlsbad Formation

Carlsbad Group.

Carnallite........ 54

Castile Formation $14,19,37,38, \$ 9,44,46,48,50,59,56,58$

Cestiles.

$14,19,37,38,89,44,46,48,60,69,66,58$

Caves.

$\begin{array}{ll}\text { Cenozoic structural features. } & \\ \text { Chalk Bluff Formation of Lang. } & 48\end{array}$

Chemical analyses of brines from wells....... $\quad \sigma_{7}$

Cherry Canyon Formation.-...-.-.-- 12,17, 26, 52

Chupadera Formation................. 23, 24, 28, 32

Climate........... 3,50

Continental Oil Co. East Teras Hill 1 well Standard Oil Co. of Teras Bass 1........ 7 , $8,9,22,23,24,40,42$

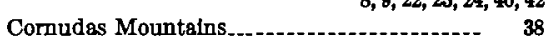

Cottonwood Cave... 48,49

Cottonwood Draw . . . . .

Cottonwood Spring......................... 46

Cretaceous rocks. . . . .

Culebra Dolomite Member of Rustler Forma. tion.

Cutoff Mountain

Cutoff Shale............... 12,17, 28

Cutoff Shaly Member of Bone Spring Limestone..................................

Cutter Formation

Cutter Member of Montoya Dolomite........ 8

\section{D}

Dark Canyon ................ $\$ 0,31,36,47,48,54$

Delaware basin

gas wells. ......... $\sigma_{4}$

oil wells.

rocks.

Delaware Mountain Formation

Delaware Mountain Group................... 12,52

Devonian rocks............................ 8

Dikes, in Castile Formation............ $\$ 9,54$ sandstone $\ldots$

Dog Canyon 25,38

Dog Canyon fault.

Dog Canyon Limestone of Lang......... 29,36

Double Canyon . .

Drainage........................................ 47

$\begin{array}{ll}\text { Drinkard Sandy Member of King } & 24 \\ \text { Dunken Dome. } & 23\end{array}$

\section{$\mathbf{E}$}

Economic geology

E1 Paso Gap. ........................... 33, 44,48

Fl Paso Gap quadrangle...................... 29

El Paso Formation . .

El Paso Ridge............................ 33, 45, 48

Ellenburger Group .......................... 7
Page

Endellite. Evaporite deposits of Ochoa Serles........---.- 19 Evaporite facies of Artesia Group........-.- 28, 99 Evaporite facies of Seven Rivers Formation.- 33, 46

Fault

Fence Canyon

Fieldwork

Fletcher Anhydrite Member of Salado Formation ...... 16

Folds

Fossils, Artesia Group.

Bliss Sandstone...........

Capitan Limestone.......-..-..--

Castile Formation................... 38

Cretaceous rocks. .

Gost Seep Dolomite.......-.......-.-. 18

Grayburg Formation

Lamar Limestone Member of Bell Canyon Formation.

McCombs Limestone Member of Bell Canyon Formation

Queen Formation.

Rustler Formation

San Andres Limestone ........................

sandstone tongue of Cherry Canyon Formation.

Seven Rivers Formation

Tansill Formation.

Yeso Formation

Franklin Mountains, Tex. ........ 5, 7,8

Fusselman Dolomite.

Gas. . .

Gas test wells. . . . .

Geography.

Geologic history

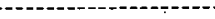

Geomorphology . . . . -

Getaway Limestone Member of Cherry Canyon Formation

Geyser Spring

Glass Mountains, Ter...

Glorieta Sandstone -

Goat Crve. . .

Gost Seep Dolomite......... 13, 18, 28, 29, 30, 32, 52

Gobbler Formation of Pray

Gravel.

Gravel of Pleistocene age

Grayburg Formation

ground water..

stratigraphic reference section

Grayburg-Queen sequence................. 31, 35, 36

Ground water.....

Guadalupe Mountains. . . . .

$10,12,18,29,37,38,45,46,54,56$

ground water.-...-. 58

scarp.

uplift.-.-.-.-.--..-... 40

Guadalupe Ridge, ground water........- 58

Guadalupe Ridge anticline.

Guadalupe Series........ 10, 12,17

Gulf Oil Corp. Estill 1-AD............... 8,10, 54 


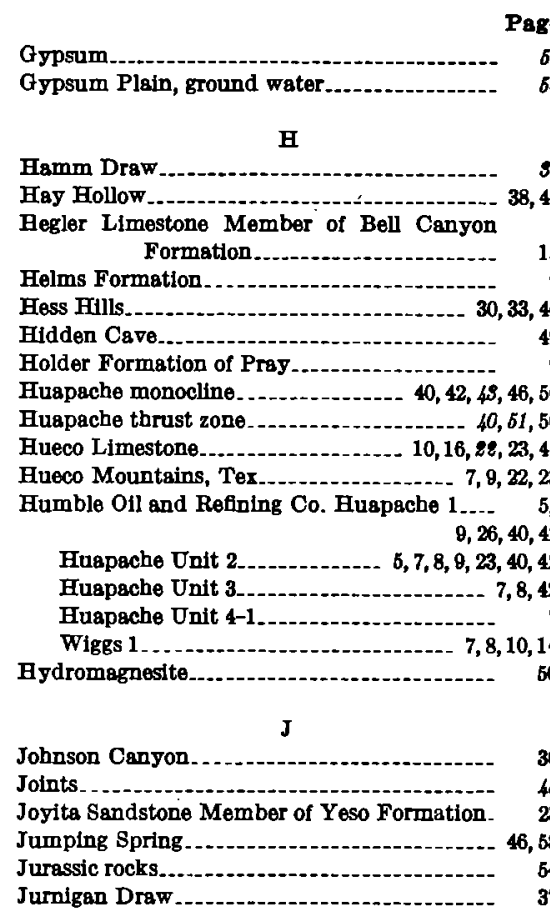

\section{$\mathbf{K}$}

King, P. B., quoted.... King, R, H, quoted Kinkaid and Watson Stanolind-Federal 1..... $\quad 32$

\section{$\mathbf{L}$}

Laborcita Formation of Otto Lakewood terrace.

Lamar Limestone Member of Bell Canyon Formation.

Landforms, major.

Lang, W. T. B., quoted.

Last Chance Canyon $25,26,27,28,29,33,36,42,47,48,64$

Lechugulle Cave.......... 45, 49 Leftbook Canyon.................... 45, 48

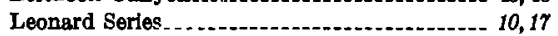

Lockhart Root Permit 2 well. ............... 29, 30

\section{$\mathbf{M}$}

McBride Randel 1 well...

McCombs Limestone Member of Bell Canyon Formation

15 Formstion

McKittrick Canyon...... 20,22

Magnolia Petroleum Co. Homer Cowden 1 well -

State "W" 1 ............. 5, 7, 9, 22, 23, 24, 25, 30

Manzanita Limestone Member of Cherry Canyon Formation...-.-.-12,19,18

Marathon uplift

Martine Ridge...... 45

Massive member of Capitan Limestone....... 20,52

Mesa del Yeso

Mescal Wash ground water.

Methods of study

Mississippian rocks

Montoya Dolomite

Montoya Limestone.

$\mathbf{N}$

New Cave $45,48,60$

Newell, N. D., and others, quoted North McKittrick Canyon..........-. 18, 19, 29, 32, 37 North Rattlesnake Canyon.......... 35 North Slaughter Canyon.

68

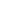

Northwest shelf . .

Page

18

orthwest-shelf area..................... 10,13,16, 52

oil test wells...

rocks.-

Ochoa Series evaporite deposits. Ocotillo Silt Member..................... 36

Ogallala Formation.............. 54

Oil ... 64

Oll fields. . .

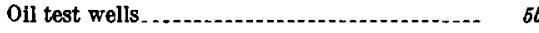

Olive, W. W., quoted .

Orchard Park terrace............ 38

Ordovician rocks. ....... 5

Ozark-Mahoning Co....................... 57

\section{$\mathbf{P}$}

Pecos Formation........ 29

Pecos section of the Great Plains province.... 46,47

Pecos Valley Red Beds of Beede........... 28

Pedernsl land mass...................... 42

Pedernal uplift of central New Mexico ..... . . 51, 52

Pennsylvanian rocks .......................... 9,23 oll.

Percha(?) Shale . ..............................

Permian rocks, stratigraphy

Petroleum.

Pinery Limestone Member of Bell Canyon

Pipeline Sh

Pisolites...................... 59,37

Plug in Bell Canyon Formation............ $\quad 40$

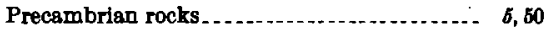

Precipitation

Pre-Permian rocks of the subsurface..........

Present investigation....................... s

$\begin{array}{ll}\text { Prevlous work. } & \text { Pump Station Hills }\end{array}$

Purpose of report ...........................

Quaternary deposits...

Queen Formation.......... 19, 28, 29, 30, 38, 39, 47, 52

stratigrapbic reference section............. 69

Queen Sand .... 30

\section{$\mathbf{R}$}

Rader Limestone Member of Bell Canyon Formation

Rattlesnake Canyon

Rattlesnake Spring ..................... 68

Read, C. B., quoted .....................

Ready Pay Member of Percha Shale.......... 8

Reef Escarpment . . $14,16,19,36,37,38,40,43,44,45,46,47$

Relations of San Andres Limestone to rocks of Delaware basin and basin-margin area, interpretation...... 27

Relief ......................... 3,52

Rim, The, Guadalupe Mountains

Roberts Canyon........................ 25, 26, 27 Rocky Arroyo....... 30, 33, 47, 54

Rocky Arroyo drainage.................... 48

Roswell artesian basin ......................

Rustler Formation.... 14, 15, 16

Sacramento Mountains, N. Mex_- $6,7,9,22,23,87,42$ Salado Formation .............. 16, 36, 58, 57 Salt Flat..................................... 38,48 San Andres Limestone.

$17,18,24,28,38,38,48,48,52$ relations to rocks of Delaware basin and basin-margin ares................ San Andres Mountains, N. Mex.......... 7,24
Sandia Formation ----1 Sandstone tongue of Cherry Canyon Formation................ 17, 28, 43 Scarps in Castlle Formation Scruton, P. C., quoted . ..... Belentte Serpentine Bends of Dark Canyon........... 47 Seven Rivers Embayment..._..... 32, 38, 46, 48, 56 ground water.......................... 68 Seven Rivers Formation....... 20, 21, 28, 31, $32,44,46$ stratigraphic reference section $\quad 60$ Seven Rivers Gypsiferous Member of Chupadera Formation...................

Seven Rivers Hills......................... Shattuck Member of Queen Formation Shattuck Valley.... .................. 30, 33, 38 Shattuck Valley escarpment ......... . 29, 31, 44, 46

Siegrest Draw Sierra Diablo, Tex................. 5, 7, 17, 22, 42 Bierrite Limestone........... 7 Sill in Carbonfferous rocks................... \$0 Silurian rocks. ................................. Simpson Group of Oklahoma, rocks correlated with........ 7

Sinkholes in Castile Formation.......... 15 Sitting Bull Canyon ............ 25, 26, 29, $99,48,68$ Bitting Bull Falls....................... 48 Sitting Bull 8pring $\ldots \ldots \ldots \ldots \ldots \ldots . . \ldots \ldots$ Sisshooter Canyon Slaughter Canyon.................. 20, 21, 35, 37, 4 Sodium sulfate................... 66 Solution-subsidence troughs.................... 46 South Rattlesnake Canyon.................... 44, 47 South Wells Limestone Member of Cherry Canyon Formation............ 12, 19, 18

Springs.......... 68

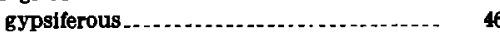

Standard of Texas Scarp Unit 1............. 42

Stone Canyon.

Stratigraphic sections......................... 69

Stratigraphy of Permian rocks .......... 10

Structural geology .......................... 40

Supertor Oil Co. Federal 1-134_........ 7,64

$\mathbf{T}$ Tank Canyon arch.
Tansill Formation................ $16,20,21,28,34,86,66$

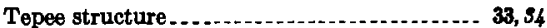

Tertlary igneous rocks...................... $s 9$

Texas craton...

Texas Hill................................ 42, 43

Teras Hill dome................................

Three Twins Member of Chalk Bluff Forms-

Topography tion

Trail Canyon.

Trlassic rocks.................... 54

Trimble Canyon . . . . . . . . . . . . . . . . 29,30

\section{$\mathrm{U}$}

Uncompahgre highland..................... 52

Unconformity, at base of sandstone tongue of Cherry Canyon Formation.......

between San Andres Limestone and Grayburg Formation ............... 43 Union Oil Co. of California Crawford 1-26.... 10,54 Crawford 2-23.......................... 54

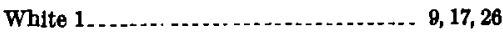
Upham Dolomite............................ 7 Upham Member of Montoya Dolomite-.... 7 Upper Dog Canyon.......... 38, 40, 44, 45, 46, 48, 58 U.S. Forest Service Recreation area .......... $\quad 58$

$\mathbf{V}$

Vegetation . . . . . . . Victorio Peak Limestone ............ 17, 23, 24, 43, 61 Victorio Peak Massive Member of Bone Spring Limestone............. 17 


\section{INDEX}

\section{$\mathbf{W}$}

Walnut Canyon $\ldots \ldots \ldots$ 34, 36, 44, 45

Walnut Canyon syncline $\ldots . . . . . . . . . . .40,44,47,54$

Walnut Creek............................ 47, 54

Wells, gas................................... 54

oill $\ldots 5,54$

West Slaughter Canyon................ 21, 44,47

White City............................ 4,45

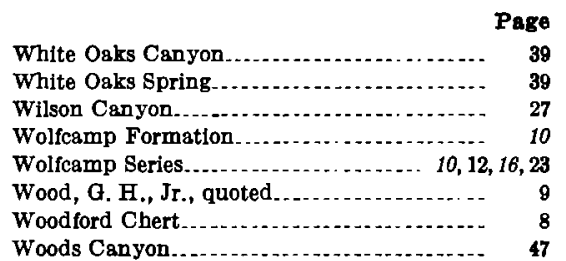

Woods Canyon

0

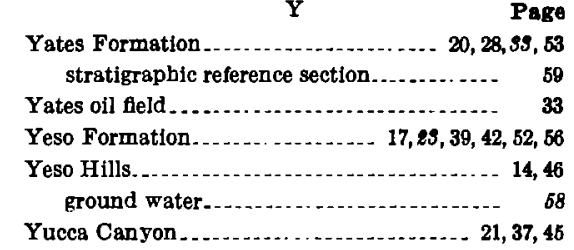

Yates Formation ................... 20, 28, 99,53 stratigraphic reference section............. 58

Yates oil field .................. 35

Yeso Hills. ..... 14, 46

Yucea Canyon ........... $21,37,45$ 






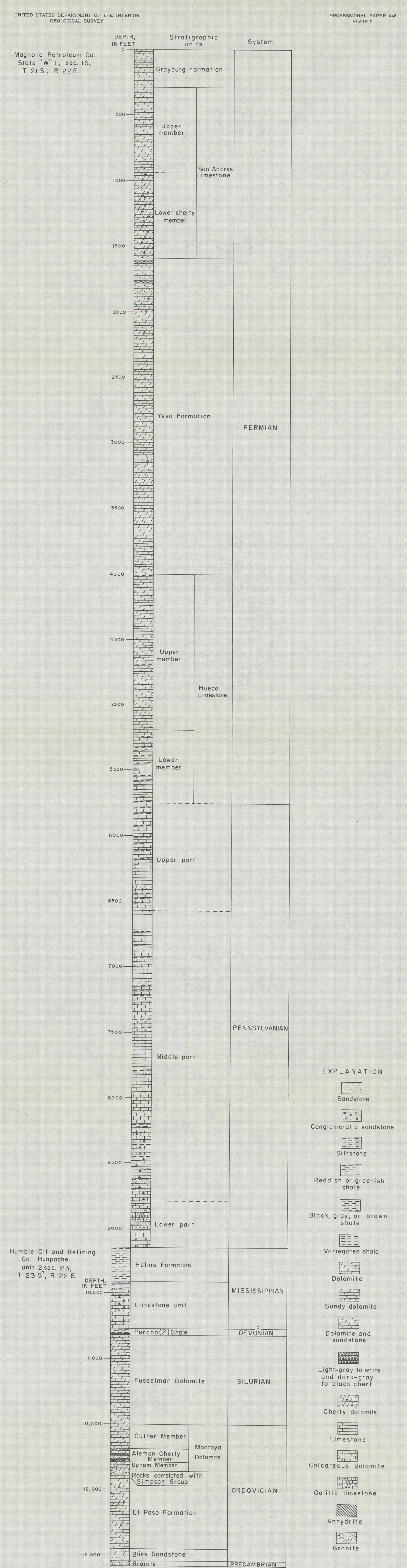
COMPOSTTE LITHOLOGIC LOG OF SUBSURFACE ROCKS IN THE SEVEN RIVERS

$$
708-3860-63 \text { (in pocket) }
$$





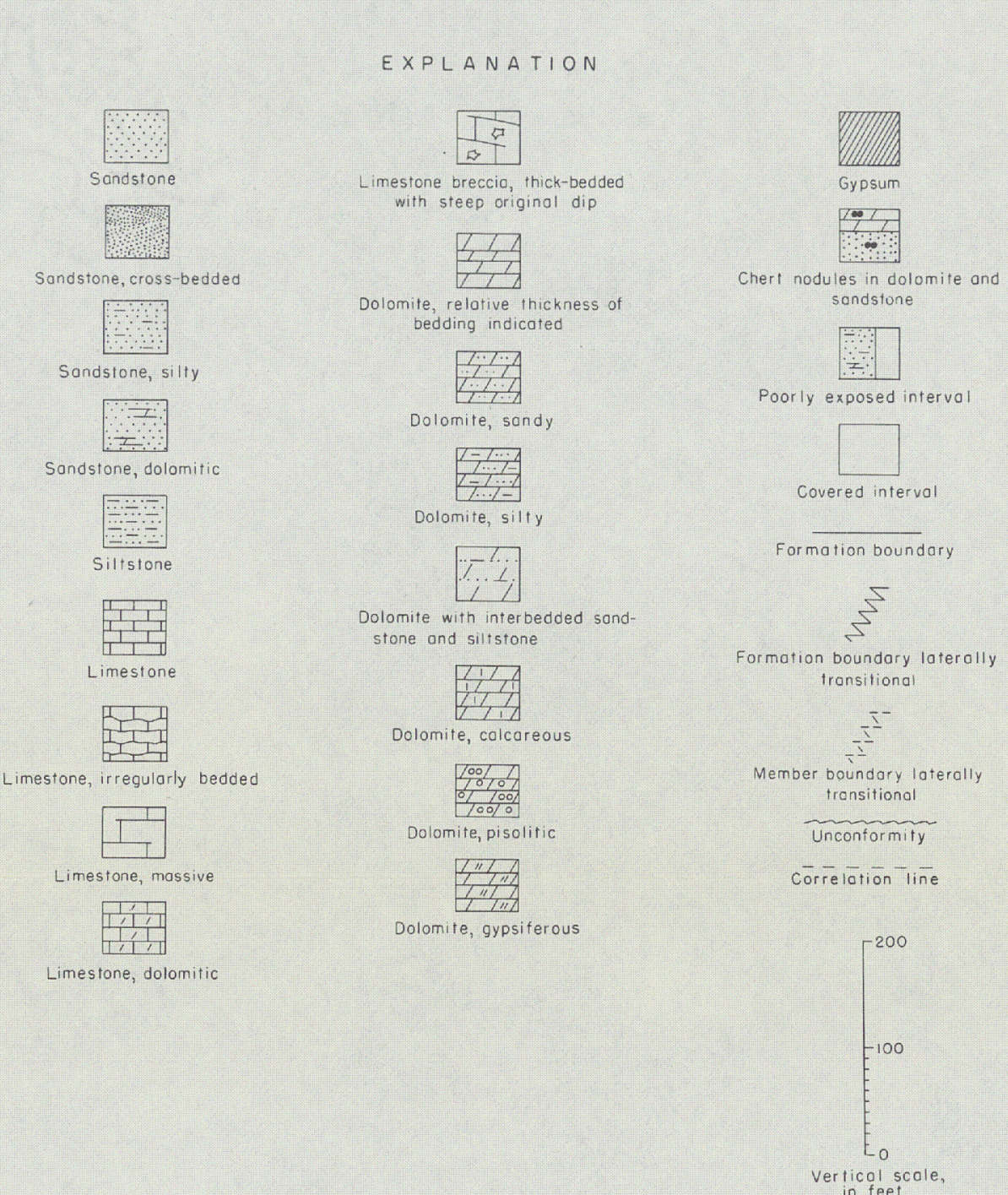

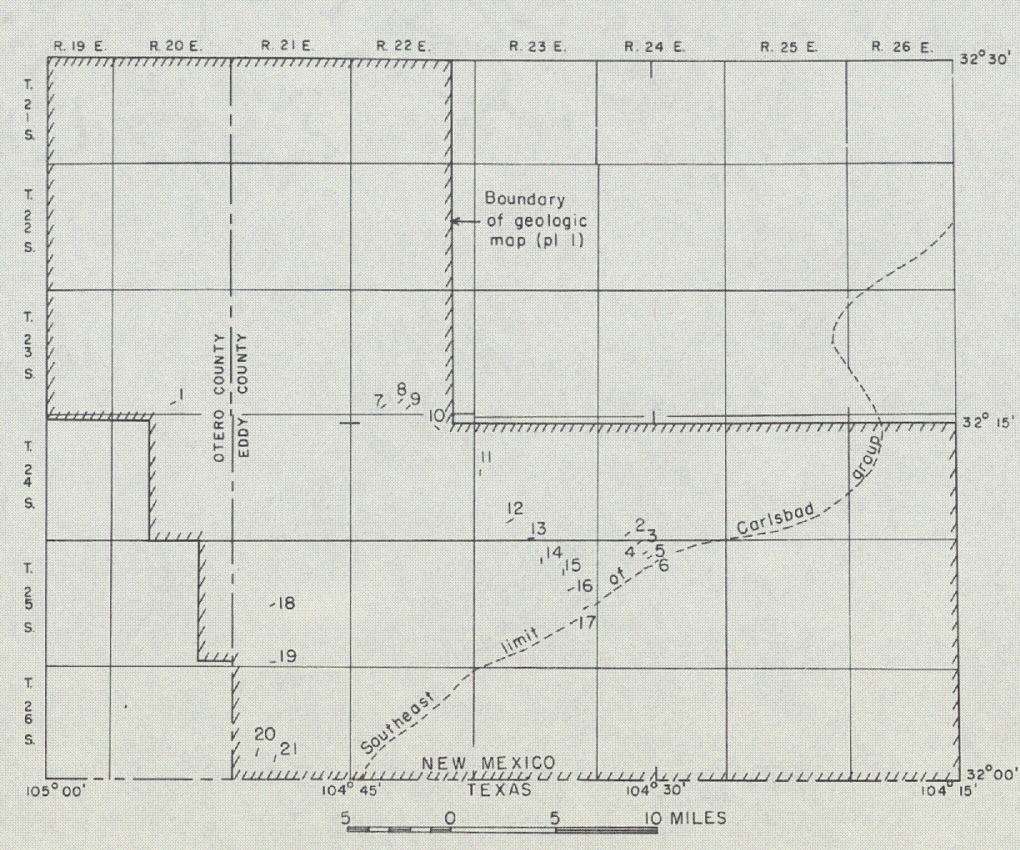
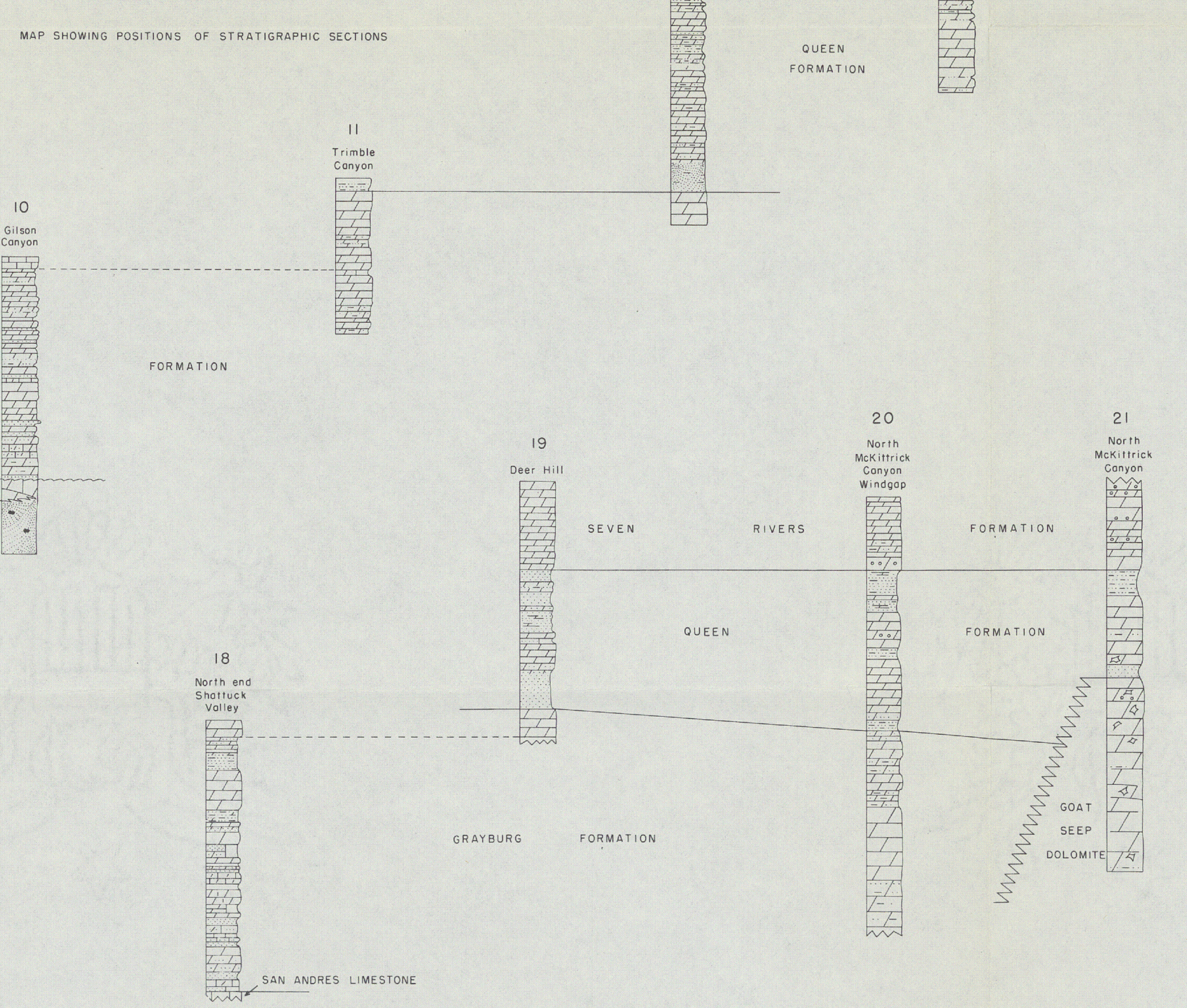

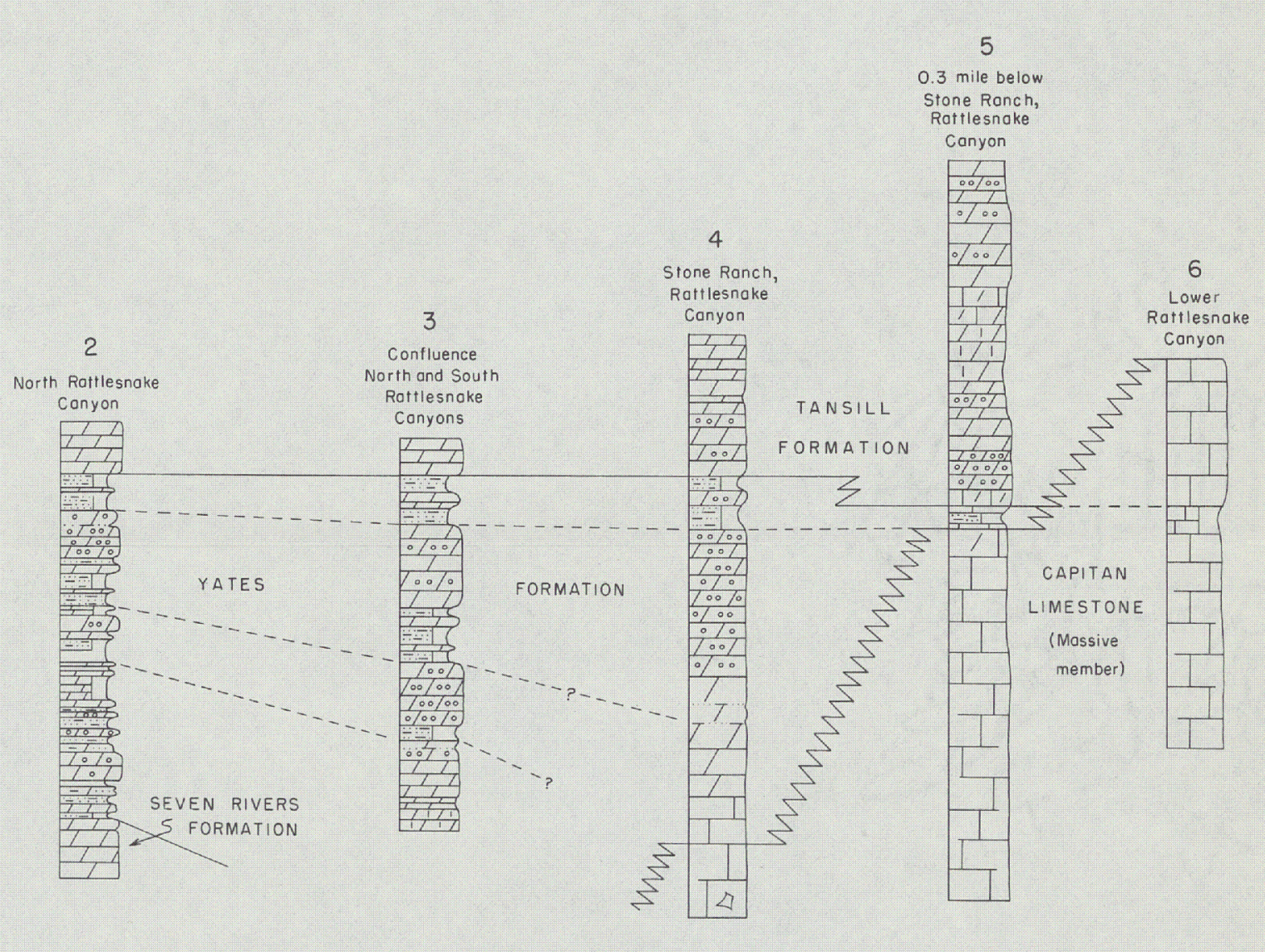

GRAPHIC SECTIONS OF PERMIAN ROCKS IN GUADALUPE MOUNTAINS, NEW MEXICO, AND STRATIGRAPHIC DIAGRAM OF ROCKS IN GUADALUPE MOUNTAINS FROM ALGERITA ESCARPMENT (NORTHWEST) TO DELAWARE BASIN (SOUTHEAST) 
